\title{
Cellular uptake and toxic effects of fine and ultrafine metal-sulfate particles in human A549 lung epithelial cells
}

\author{
Mathias Könczöl, ${ }^{\dagger,}$ Ella Goldenberg, ${ }^{\S}$ Sandra Ebeling,,${ }^{,}$Bianca Schäfer,,${ }^{+}$Manuel Garcia- \\ Käufer, ${ }^{\dagger}$ Richard Gminski, ${ }^{\prime}$, Bernard Grobéty, $\|$ Barbara Rothen-Rutishauser, ${ }^{\perp}$ Irmgard \\ Merfort, ${ }^{+}$Reto Gieré, $*{ }^{\S}$ and Volker Mersch-Sundermann $*{ }^{*}$
}

Correspondence: Mathias Könczöl, Department of Pharmaceutical Biology and Biotechnology, University of Freiburg, Stefan-Maier-Str. 19, D-79104 Freiburg, Germany.

E-mail: mathias.koenczoel@,pharmazie.uni-freiburg.de

* shared senior authorship

$\uparrow$ Department of Environmental Health Sciences, University Medical Center Freiburg, Freiburg, Germany

* Department of Pharmaceutical Biology and Biotechnology, University of Freiburg, Freiburg, Germany

$\S$ Institute of Geosciences, University of Freiburg, Freiburg, Germany

${ }^{\|}$Department of Geosciences and FRIMAT, University of Fribourg, Fribourg, Switzerland

${ }^{\perp}$ Adolphe Merkle Institute, University of Fribourg, Fribourg, Switzerland

Key words: metal sulfates; $\mathrm{CaSO}_{4} ; \mathrm{Zn}$ sulfate; $\mathrm{PbSO}_{4}$; NF-кB; DNA and chromosomal damage; TEM; particle uptake

Running title: Toxic effects of metal-sulfate particles 
Table of Contents

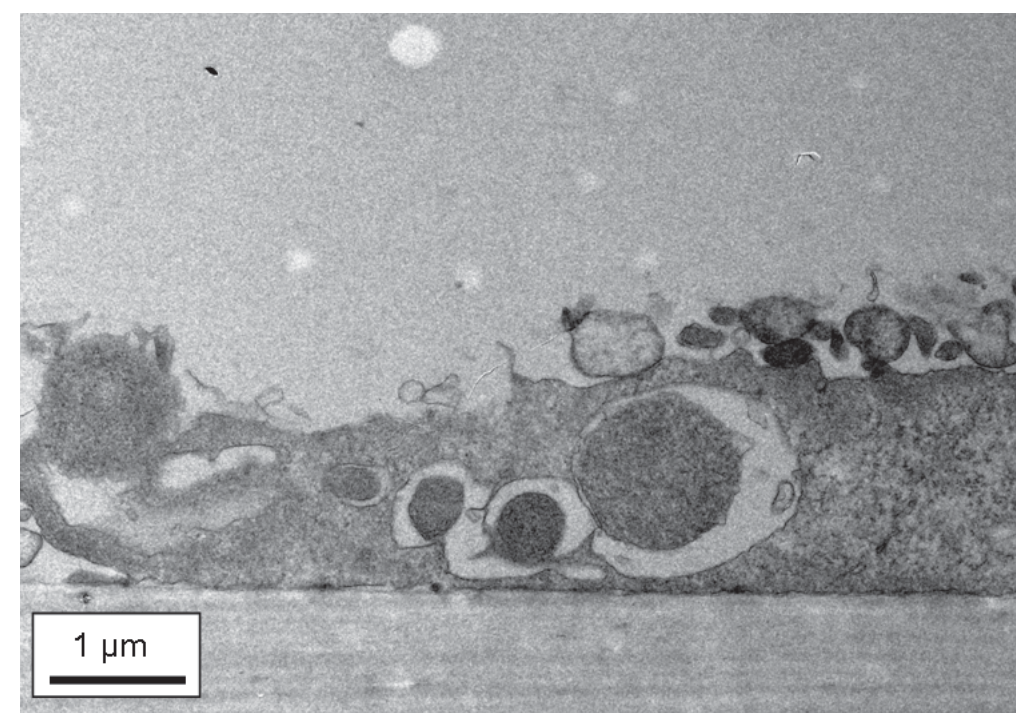

$\frac{1}{0}$
0
$\frac{0}{0}$
0
0
0
0
0
0 


\section{ABSTRACT}

Ambient airborne particulate matter is known to cause various adverse health effects in humans. In a recent study on the environmental impacts of coal and tire combustion in a thermal power station fine crystals of $\mathrm{PbSO}_{4}$ (anglesite), $\mathrm{ZnSO}_{4} \cdot \mathrm{H}_{2} \mathrm{O}$ (gunningite), and $\mathrm{CaSO}_{4}$ (anhydrite) were identified in the stack emissions. Here, we have studied the toxic potential of these sulfate phases as particulates and their uptake in human alveolar epithelial cells (A549). Both $\mathrm{PbSO}_{4}$ and $\mathrm{CaSO}_{4}$ yielded no loss of cell viability, as determined by the WST-1 and NR assays. In contrast, a concentration-dependent increase in cytotoxicity was observed for $\mathrm{Zn}$ sulfate. For all analyzed sulfates, an increase in the production of reactive oxygen species (ROS), assessed by the DCFH-DA assay and EPR, was observed, although to a varying extent. Again, Zn sulfate was the most active compound. Genotoxicity assays revealed concentration-dependent DNA damage and induction of micronuclei for $\mathrm{Zn}$ sulfate and, to a lower extent, for $\mathrm{CaSO}_{4}$, whereas only slight effects could be found for $\mathrm{PbSO}_{4}$. Moreover, changes of cell cycle were observed for $\mathrm{Zn}$ sulfate and $\mathrm{PbSO}_{4}$. It could be shown further that $\mathrm{Zn}$ sulfate increased the nuclear factor kappa-B (NF- $\mathrm{B}$ ) DNA binding activity and activated JNK. During our TEM investigations, no effect on the appearance of the A549 cells exposed to $\mathrm{CaSO}_{4}$ compared to the non-exposed cells was observed, and in our experiments only one $\mathrm{CaSO}_{4}$ particle was detected in the cytoplasm. In the case of exposure to $\mathrm{Zn}$ sulfate, no particles were found in the cytoplasm of A549 cells, but we observed a concentrationdependent increase in the number and size of dark vesicles (presumably zincosomes). After exposure to $\mathrm{PbSO}_{4}$, the A549 cells contained isolated particles as well as agglomerates both in vesicles and in the cytoplasm. Since these metal-sulfate particles are emitted into the atmosphere via the flue gas of coal-fired power stations, they may be globally abundant. Therefore, our study is of direct relevance to the population living near such power plants. 
Abbreviations: Ethyl methanesulfonate, EMS; Potassium superoxide, $\mathrm{KO}_{2}$; nano-Carbon Black, nCB; Krebs-Hepes-Buffer, KHB; 1-hydroxy-3-methoxycarbonyl-2,2,5,5-tetramethylpyrrolidine, $\mathrm{CMH}$; electron paramagnetic resonance, EPR; Cytokinesis Block Micronucleus Assay, CB-MNvit; c-Jun N-terminal kinase, JNK; NADPH-oxidase, NOX; lipidperoxidation, LPO; malondialdehyde, MDA; superoxide dismutase, SOD; bicinchoninic acid, BCA. 


\section{INTRODUCTION}

Airborne particulate matter (PM) is known to cause adverse health effects in humans, including respiratory and cardiovascular diseases. ${ }^{1 ; 2}$ In several epidemiological studies, an increased mortality or cancer rate has been linked to a higher burden of particles in ambient air. ${ }^{3 ; 4}$ In a recent study, we have investigated comprehensively the cytotoxic and genotoxic effects in A549 human lung epithelial cells of certain particulates from industrial sources. ${ }^{5 ; 6}$ Particulate emissions from various industries contribute notably to the atmospheric PM.-9 Coal-fired power plants emit substantial amounts of fine particles into the atmosphere, where they will be distributed by atmospheric circulation and eventually removed by precipitation or gravitational settling. Stack emissions resulting from combustion of coal and coal+tire mixtures in a commercial power plant have been shown to contain various types of crystalline metal sulfates, including: $\mathrm{PbSO}_{4}$ (anglesite), $\mathrm{ZnSO}_{4} \cdot \mathrm{H}_{2} \mathrm{O}$ (gunningite), and $\mathrm{CaSO}_{4}$ (anhydrite). ${ }^{10 ; 11}$ Additionally, Ca sulfates (anhydrite, gypsum) are not only emitted by anthropogenic sources, but are also a common component of natural atmospheric PM. ${ }^{12}$ Experiments on bioaccessibility of the emitted $\mathrm{PM}$ revealed substantial amounts of $\mathrm{Pb}$ and $\mathrm{Zn}$ available in simulated lung fluids. ${ }^{13}$ People living near coal-fired power stations may inhale the emitted particles and possibly experience adverse health effects.

So far, information on the potential toxicity of such metal-sulfate particles is fragmentary. $\mathrm{PbSO}_{4}$, an orthorhombic mineral, is classified in group 2A, i.e. probably carcinogenic to humans, ${ }^{14}$ and thus its use in paints was discontinued in the US in 1978. More information is available on general $\mathrm{Pb}$ poisoning. Whereas acute effects were only observed for high millimolar $\mathrm{Pb}$ concentrations, ${ }^{15}$ chronic exposure is known to cause genetic damage in humans. ${ }^{16 ; 17}$ Lead enters the human body mainly through inhalation and ingestion ${ }^{18}$ and can accumulate, damaging the nervous system and leading to brain disorders. It exerts its toxic effect by altering biomembrane structures and functions. ${ }^{19}$ Reaction with thiols leads to 
depletion of glutathione (GSH) and a consecutive imbalance of cellular defense mechanisms, resulting in oxidative stress. ${ }^{20}$ Several studies focused on the speciation and characterization of Pb-containing PM, ${ }^{21-24}$ but only few data exist on the toxicity of these particles. Uzu et al. found slight cytotoxic effects and increased cytokine release in $16 \mathrm{HBE} 140$ cells after exposure to $\mathrm{Pb}$-rich $\mathrm{PM}{ }^{18}$ These effects were linked to total $\mathrm{Pb}$ content but were inversely related to $\mathrm{Pb}$ solubility. Other in-vitro studies revealed increased oxidative stress, cytotoxicity, and genotoxicity after exposure to soluble $\mathrm{Pb}$ compounds. ${ }^{25 ; 26}$

Health effects caused by $\mathrm{CaSO}_{4}$ particulates in ambient air have so far not been investigated in detail. Poorly soluble Ca compounds are not considered harmful, but adverse effects of $\mathrm{Ca}$ sulfate (in PM) on human health are controversial. ${ }^{27 ; 28}$ In cement-related studies, $\mathrm{CaSO}_{4}$ was tested for its cytotoxic, genotoxic and ROS-generating potential in V79 cells, but no effects were observed for concentrations up to $20 \mu \mathrm{g} / \mathrm{cm}^{2}{ }^{29}$ For concentrations $>25 \mu \mathrm{g} / \mathrm{cm}^{2}$, cytotoxic effects in IMR90 lung cells were observed. ${ }^{30}$ At lower concentrations, Ca plays a vital physiological role. Thus, within the framework of the cellular $\mathrm{Ca}$ homeostasis, intake, signaling and storage of $\mathrm{Ca}$ is regulated and controlled, ${ }^{31}$ and deregulation of $\mathrm{Ca}$ homeostasis can result in proinflammatory effects and cell death, a process already observed after exposure of monocytes to ambient $\mathrm{PM}_{10}$ and Carbon Black nanoparticles (nCB). These effects can be reduced by adding verapamil. ${ }^{32}$

Although toxicity data for Zn-sulfate phases are scarce, several studies on the toxicity of other $\mathrm{Zn}$ compounds (e.g., $\mathrm{ZnO}, \mathrm{ZnCl}_{2}$ ) exist. It is known, for example, that oral administration of Zn compounds leads to acute and chronic effects only at high concentrations (corresponding to $>150 \mathrm{mg}$ elemental $\mathrm{Zn}){ }^{33}$ but inhalation of small concentrations of $\mathrm{ZnO}\left(5 \mathrm{mg} / \mathrm{m}^{3}\right)$ can induce "metal fume fever" in humans: ${ }^{34}$ The toxic potential of $\mathrm{Zn}$ compounds and $\mathrm{Zn}$ containing PM is still a matter of debate. After instillation in rodents, proinflammatory effects 
were observed, which could be correlated to the amount of soluble $\mathrm{Zn} .{ }^{35 ; 36}$ Furthermore, recent in-vitro studies revealed cytotoxic and genotoxic effects of various $\mathrm{Zn}$ compounds. ${ }^{37-39}$

To gain information on the potential toxicity of metal-sulfate particles we have investigated the three sulfate compounds anglesite, gunningite, and anhydrite in regard to their cytotoxic and genotoxic effects, ROS formation and impact on cell cycle in A549 human lung epithelial cells. Moreover, their influence on the NF-KB and JNK signaling pathways was determined. We have chosen these three phases because they are emitted into the atmosphere by combustion of coal and coal+tire mixtures and because they display very different physical, chemical and structural properties. Prior to the cell-exposure experiments, the used sulfate samples were characterized by mineralogical methods, including powder X-ray diffraction (XRD), scanning electron microscopy (SEM), laser diffraction, and atomic absorption spectroscopy (AAS). In addition, we investigated whether or not particles were incorporated into the cells and, if so, in which parts of the cells by means of transmission electron microscopy (TEM) combined with energy-dispersive X-ray (EDX) spectroscopy.

\section{MATERIALS AND METHODS}

\section{Chemicals and Reagents}

EMS with a purity of $>99 \%$ (CAS-No 62-50-0) and $\mathrm{KO}_{2}$ were obtained from Alfa Aesar (Karlsruhe, Germany). Stock-solutions were made with DMSO. RPMI 1640 medium was obtained from Invitrogen (Darmstadt, Germany). L-glutamine, Fetal Bovine Serum (FBS), trypsine/EDTA and phosphate-buffered saline (PBS) were purchased from PAA (Parsching, Austria). Valinomycin, propidiumiodide (PI), DCFH-DA $\left(2^{\prime}-7^{\prime}\right.$-dichloro-fluorescin diacetate), DMSO, neutral red, cytochalasin $\mathrm{B}, \mathrm{H}_{2} \mathrm{O}_{2}(30 \%)$, ethidiumbromide for microscopy was obtained from Sigma-Aldrich (Taufkirchen, Germany). KHB and CMH were purchased from Noxygen Science Transfer \& Diagnostics GmbH (Elzach, Germany). 


\section{Particle Source and Sample Preparation}

$\mathrm{CaSO}_{4}$ anhydrous powder (99\% min, CAS-No. 7778-18-9) was obtained from Alfa Aesar, Karlsruhe, Germany and used as delivered. $\mathrm{ZnSO}_{4} \cdot 7 \mathrm{H}_{2} \mathrm{O}$ (pro analysi, CAS-No. 7446-20-0) was ordered at Merck Chemicals, Darmstadt, Germany and ground in dry form in an agate mortar. $\mathrm{PbSO}_{4}$ (lead(II) sulfate Puratronic 99.999\% metals basis, CAS-No. 7446-14-2) was obtained from Alfa Aesar, Karlsruhe, Germany and milled 30 min in distilled $\mathrm{H}_{2} \mathrm{O}$ in a corundum McCrone Micronizing Mill. $\mathrm{ZnCl}_{2}$ (CAS No. 7646-85-7) was supplied by Sigma Aldrich, Steinheim. The particle positive control quartz $\left(\mathrm{SiO}_{2}\right.$, Min-U-Sil 5) was kindly provided by US Silica, Berkeley Springs, USA. Prior to chemical and physical characterization, and before preparing the suspensions for our experiments, all particle samples were baked for $4 \mathrm{~h}$ at $180^{\circ} \mathrm{C}$ (Heraeus KR 170E) to destroy endotoxins that might cause false-positive results in the bioassays, especially in regard to signaling cascades. During heating, $\mathrm{ZnSO}_{4} \cdot 7 \mathrm{H}_{2} \mathrm{O}$ looses water and undergoes a phase transition to $\mathrm{ZnSO}_{4} \cdot \mathrm{H}_{2} \mathrm{O}$ (gunningite).

\section{Particle Characterization}

Scanning Electron Microscopy (SEM): A scanning electron microscope (LEO FE 1525) was used in combination with an Oxford Instruments (Abingdon, UK) EDX system (SEM-EDX) to determine size, composition and shape of the particles. The particles were suspended in isopropanol (pro analysi, Merck Chemicals, Darmstadt, Germany) and sonicated for 20 minutes at $25^{\circ} \mathrm{C}$ in an ultrasonic water bath. Subsequently, the suspensions were pipetted onto an aluminum SEM-sample holder covered by a carbon pad (Plano GmbH, Wetzlar, Germany) and coated with $20 \mathrm{~nm}$ carbon using an Edwards Auto206 carbon coater. In each sample, EDX spectra were obtained from approximately 100 individual particles to determine the chemical composition of the particles and used to identify possible contamination particles. Such particles can be detected also by scanning the sample in backscattered electron (BSE) 
mode, which allows for distinction of different particle types on the basis of their grey-scale values, which correlate with the mean atomic number.

$X$-ray diffraction $(X R D)$ : The metal sulfates were characterized by powder XRD using a Bruker AXS D8 Advance diffractometer. The particles were dispersed with acetone $\left(\mathrm{PbSO}_{4}\right.$, $\left.\mathrm{CaSO}_{4}\right)$ or in dry form $\left(\mathrm{ZnSO}_{4} \cdot \mathrm{H}_{2} \mathrm{O}\right)$ onto zero-background $\mathrm{Si}$ sample holders and then scanned from 2 to $60^{\circ} 2 \theta$ with a step size of $0.01^{\circ}$ and a dwell time of $4 \mathrm{~s} / \mathrm{step}$ using $\mathrm{Cu}-\mathrm{K} \alpha$ radiation. The spectra were compared with the ICPDF database in order to identify the phases and test for the possible presence of impurity phases in the powders. Because gunningite is hygroscopic and tends to be transformed into other Zn-sulfate-hydrates, ${ }^{40}$ a sample of the Znsulfate material was subjected to XRD analysis again after storage in a closed container for a period of $\sim 12$ months. The XRD data obtained from this sample were processed by Rietveld refinement (TOPAS software, version 3.0, Bruker Inc.) using the fundamental parameter approach $^{41}$ to determine the phases present and their concentrations. For more detailed information, the reader is referred to the Supporting Information.

Atomic absorption spectroscopy (AAS): To determine the bulk chemical composition of the sulfates, the samples were analyzed by AAS after total digestion. $\mathrm{CaSO}_{4}$ and $\mathrm{Zn}$ sulfate were digested in $\mathrm{H}_{2} \mathrm{O}$ at room temperature, whereas the poorly soluble $\mathrm{PbSO}_{4}$ was digested in an acid mixture consisting of $8 \mathrm{~mL} \mathrm{HNO}_{3}(65 \%)$ and $2 \mathrm{~mL} \mathrm{H}_{2} \mathrm{O}_{2}(30 \%)$ at $200^{\circ} \mathrm{C}(10 \mathrm{~min})$ in a microwave oven (MLS $\mu$ PREP-A). Aluminum, $\mathrm{Ba}, \mathrm{Cd}, \mathrm{Fe}, \mathrm{Mn}, \mathrm{Ni}$ and $\mathrm{Pb}$ were analyzed by graphite-furnace AAS (Perkin-Elmer 4110 ZL Zeeman), and $\mathrm{Ca}, \mathrm{Mg}, \mathrm{Na}$ and $\mathrm{Zn}$ by flame AAS (Analytik Jena, AAS Vario 6). Each measurement was repeated three times using the standard method (direct analysis of the solution of interest after calibration with a respective standard with known concentration). AAS was also used to determine the metal concentrations in the culture medium at the experimental conditions, i.e. at $37^{\circ} \mathrm{C}$ and a pH of 7.4. For this purpose, the sulfate powders were suspended in pure RPMI or RPMI 
supplemented with $5 \% \mathrm{FBS}$, then sonicated for $20 \mathrm{~min}$ in an ultrasonic water bath at $37{ }^{\circ} \mathrm{C}$ (Bandelin Sonorex RK510H), and subsequently centrifuged at $4000 \mathrm{rpm}$ for $2 \mathrm{~min}$ (Heraeus Biofuge Primo Centrifuge). Concentrations of $\mathrm{Ca}, \mathrm{Zn}, \mathrm{Pb}$ and $\mathrm{Fe}$ were determined in the supernatants of these sulfate suspensions as well as in the media devoid of particles (RPMI and RPMI+5\% FBS). Each AAS measurement was repeated three times using the standard method. As the analysis of $\mathrm{Ca}$ showed matrix effects, the accumulation method (measurement of $\mathrm{n}$ samples, each being prepared with the same amount of solution of interest, but different amounts of standard with known element concentration) was applied additionally to verify the Ca concentrations.

Laser diffraction: The particle-size distribution of the sulfate powders was determined by laser diffraction (Malvern Mastersizer 2000) using isopropanol as dispersant during analysis. For this purpose, the sulfate powders were suspended in isopropanol and sonicated $20 \mathrm{~min}$ in an ultrasonic water bath at $25{ }^{\circ} \mathrm{C}$ to minimize agglomeration of particles. Isopropanol was chosen as dispersant to minimize particle dissolution before and during laser diffraction analysis. Therfore, the obtained particle diameters can be considered as maximum values. The data were processed with the Mastersizer Microplus software (version 2.19) based on the assumption of equivalent diameters of the particles and by using a density of $2.98 \mathrm{~g} / \mathrm{cm}^{3}$ for $\mathrm{CaSO}_{4}, 3.195 \mathrm{~g} / \mathrm{cm}^{3}$ for $\mathrm{ZnSO}_{4} \cdot \mathrm{H}_{2} \mathrm{O}, 2.41 \mathrm{~g} / \mathrm{cm}^{3}$ for $\mathrm{ZnSO}_{4} \cdot 4 \mathrm{H}_{2} \mathrm{O}$, and $6.38 \mathrm{~g} / \mathrm{cm}^{3}$ for $\mathrm{PbSO}_{4}$, the refractive indices of $1.61\left(\mathrm{CaSO}_{4}, \mathrm{ZnSO}_{4} \cdot \mathrm{H}_{2} \mathrm{O}\right), 1.52\left(\mathrm{ZnSO}_{4} \cdot 4 \mathrm{H}_{2} \mathrm{O}\right), 1.87\left(\mathrm{PbSO}_{4}\right)$, and 1.39 (isopropanol), and imaginary refractive indices of 0.3 for the sulfates. ${ }^{42}$

\section{Solubility Modeling}

The thermodynamic software package PHREEQC for Windows ${ }^{43}$ was used to calculate the phases that are likely to precipitate at $37{ }^{\circ} \mathrm{C}$ at a $\mathrm{pH}$ of 7.4 from the RPMI culture medium as well as from the particle-containing culture medium solutions. The thermo LLNL (Lawrence Livermore National Laboratorv) database. concentrations of inorganic salts of RPMI 
according to the provider, and our AAS data were used for the solution calculations. In order to obtain an idea on what might happen with our particles or suspensions inside acidic vesicles (e.g., lysosomes) we also performed the PHREEQC calculations at a lysosomal $\mathrm{pH}$ of 4.5 .

\section{Preparation of Particle Suspensions}

Metal-sulfate particle suspensions were prepared freshly prior to each experiment. Particles were suspended in FBS-free culture medium supplemented with 1 vol\% L-glutamin and $1 \mathrm{vol} \%$ penicillin/ streptomycin to a concentration of $5 \mathrm{mg} / \mathrm{mL}$. These suspensions were sonicated for $20 \mathrm{~min}$ at $40^{\circ} \mathrm{C}$ in an ultrasonic water bath (Sonorex Bandelin, Berlin, Germany) to ensure homogeneous suspensions. Subsequently, the suspensions were diluted in FBS-free culture medium to obtain the required concentrations for each bioassay. Cells were washed with PBS and culture media containing 10\% FBS was provided before adding the particle suspensions. In each bioassay, the volume of culture media was adjusted to obtain the same corresponding concentration of particles in $\mu \mathrm{g} / \mathrm{mL}$. The concentrations $10,50,100$, $200 \mu \mathrm{g} / \mathrm{cm}^{2}$ refer to $16,80,160,320 \mu \mathrm{g} / \mathrm{mL}$ in all bioassays. Only in CB-MNvit, volume of culture media could not be adjusted due to a different surface area. Here, a concentration of $10 \mu \mathrm{g} / \mathrm{cm}^{2}$ refers to $39.5 \mu \mathrm{g} / \mathrm{mL}$.

\section{Cell Culture and Cell Treatment}

For all experiments, we used the human lung adenocarcinoma type-II alveolar epithelial cells A549, obtained from the DSMZ (Deutsche Sammlung von Mikroorganismen und Zellkulturen GmbH, Braunschweig, Germany). The cells, derived from an individual with alveolar cell carcinoma, ${ }^{44}$ have been used extensively to assess type-II cell function, because many characteristics of normal type-II cells are retained. The cells were cultured in RPMI culture medium supplemented with 10\% FBS, 1 vol $\%$ L-glutamin, 1 vol $\%$ penicillin/ 
streptomycin in a humidified incubator at $37^{\circ} \mathrm{C}$ with 5 vol $\% \mathrm{CO}_{2}$. For the experiments, cells were trypsinised at $80-90 \%$ confluency, seeded into well tissue plates (Greiner, Frickenhausen, Germany) and exposed at $37{ }^{\circ} \mathrm{C}$ in a humidified atmosphere containing 5 $\operatorname{vol} \% \mathrm{CO}_{2}$.

\section{Particle Uptake and Localization}

Uptake of metal-sulfate particles at different concentrations $\left(1\right.$ and $10 \mu \mathrm{g} / \mathrm{cm}^{2}$ for $\mathrm{Zn}$ sulfate, $50 \mu \mathrm{g} / \mathrm{cm}^{2}$ for $\mathrm{CaSO}_{4} ; 100 \mu \mathrm{g} / \mathrm{cm}^{2}$ for $\mathrm{CaSO}_{4}$ and $\mathrm{PbSO}_{4}$ ) and exposure times (24 $\mathrm{h}$ for all sulfates, additionally $4 \mathrm{~h}$ for $\mathrm{CaSO}_{4}$ and $\mathrm{PbSO}_{4}$ ) was investigated by TEM imaging (Philips CM200 instrument equipped with an EDX [EDAX] spectrometer). Preparation of the samples to be examined by TEM was identical to that described by Könczöl et al. ${ }^{6}$ As a control, we examined A549 cells that were not exposed to particles, but prepared in the same manner as the A549 cells exposed to metal-sulfate particle suspensions.

For each sample, between 80 and 120 cells were examined. EDX spectra (spot scan) were collected from the actual particles. Moreover, we performed EDX spot and area scans on the cytoplasm and the vesicles, as well as on the stain used as part of the sample preparation. The $\mathrm{PbSO}_{4}$ particles were more difficult to identify because of two reasons: 1) the contrasting medium used during sample preparation contains $\mathrm{Pb}$, and 2) the $\mathrm{S}-\mathrm{K} \alpha$ peak overlaps with the $\mathrm{Pb}-\mathrm{M} \alpha$ peak. Therefore, the $\mathrm{PbSO}_{4}$ samples had to be investigated much more meticulously. In two instances, we were able to generate selected area electron diffraction patterns (not shown), which proved unequivocally that the particles were anglesite. Furthermore, at large magnification, stain and particles are in most cases easy to distinguish due to their different shape and structures.

\section{Cytotoxicity Assays}


We have chosen two different endpoints to investigate cytotoxic effects: the WST-1 assay (Roche Diagnostics, Mannheim, Germany), which assesses the cellular activity, and the neutral red (NR)-uptake assay, which indicates lysosomal integrity. The assay was performed in a 96-well plate with $2 \times 10^{4}$ cells in $200 \mu \mathrm{L}$ culture media containing $5 \%$ FBS. The details of the assays have been published recently. ${ }^{6}$ First, experiments were performed to rule out interferences between the particle samples and the detection systems or the assay reagents. No adsorption of the dyes to the metal-sulfate particles was observed, nor was light absorption influenced for the concentrations tested.

\section{Analysis of Intracellular ROS Production}

The level of intracellular oxidative stress was measured by the DCFH-DA assay and by EPRmeasurement. The assay was performed in a black 96-well plate with $2 \times 10^{4}$ cells in $200 \mu \mathrm{L}$ culture media containing 5\% FBS. A detailed description of the procedure of the DCFH-DA assay can be found in Könczöl et al. ${ }^{6}$ Results from the DCFH-DA assay were combined with the protein content of A549, as a marker of cell viability, providing a good understanding of particle-induced oxidative stress. ${ }^{45}$ After fluorescence measurement, the 96-well plate was frozen at $-80{ }^{\circ} \mathrm{C}$ for quantification of total protein content using the BCA assay. Fluorescence intensity was expressed in relative fluorescence units (RFU) per $\mu \mathrm{g}$ protein compared to control cells without particle treatment. Quartz $\left(\mathrm{SiO}_{2} ; \mathrm{Min}-\mathrm{U}-\mathrm{Sil} 5\right)$ was used as positive control. Each experiment was performed independently in triplicate.

For the EPR experiments, 4 × $10^{5}$ cells were seeded in 12-well plates, incubated for $24 \mathrm{~h}$ and exposed to the particle samples in $2 \mathrm{~mL}$ culture media containing 5\% FBS. After exposure, cells were washed with KHB and incubated for 30 min with $500 \mu \mathrm{L}$ KHB containing the spin probe $\mathrm{CMH}(200 \mu \mathrm{M})$. Subsequently, the cells were kept on ice until the EPR measurement was performed. EPR (e-scan EPR, model NOX-E.11-ESR, Noxygen Science Transfer \& Diagnostics GmbH, Elzach, Germany) was carried out using the following parameters: Scans 
5; Attenuator $3 \mathrm{~dB}$; Sweep time $5.24 \mathrm{~s}$; Center field 3460.546. A cell-free CMH sample was used to assess auto oxidation of the spin probe, which was subtracted from all samples. Additionally, all particle samples were analyzed directly with $\mathrm{CMH}$ in a cell-free environment to elucidate possible interactions between the spin probe and the particles. The same analysis was carried out after 24-h incubation of the particle samples in culture media without cells to assess the influence of culture media and serum on the particles. As positive control, potassium superoxide was added to $\mathrm{CMH}$, leading to complete oxidation of the spin probe.

\section{Mitochondrial Membrane Potential (MMP)}

Measurement of the MMP was carried out with the fluorescent dye JC-1 via flow cytometry, as described by Zhao et al. ${ }^{46}$

\section{Cell Cycle Measurement}

$2.5 \times 10^{5}$ cells were seeded in 12-well plates, incubated for $24 \mathrm{~h}$ and exposed to the particle samples in $2 \mathrm{~mL}$ culture media containing 5\% FBS. After exposure, the cells were washed with PBS, trypsinized, and collected by centrifugation at $1500 \mathrm{rpm}$ for $5 \mathrm{~min}$ at $4^{\circ} \mathrm{C}$. Cells were fixed in $2 \mathrm{~mL}$ of ice-cold $70 \%$ ethanol and kept at $4{ }^{\circ} \mathrm{C}$ until analysis. For flow cytometry, cells were centrifuged at $1500 \mathrm{rpm}$ for $10 \mathrm{~min}$ and re-suspended in PBS containing $0.1 \mathrm{mg} / \mathrm{mL}$ RNAse and $0.25 \mathrm{mg} / \mathrm{mL}$ PI. Cell-cycle distribution was examined by measuring DNA content of $1 \times 10^{4}$ cells using a flow cytometer (FACScalibur).

\section{Genotoxicity Assays}

For the assessment of the genotoxic effects caused by the metal-sulfate samples two different assays were used. The Single-Cell Gel Electrophoresis (SCGE, Comet-Assay) was carried out to determine double and single DNA-strand breaks in A549 cells. The CB-MNvit was performed according to the OECD guideline ${ }^{47}$ and the protocol of Fenech et al. ${ }^{48}$ It provides 
information on the chromosome-damaging potential of the investigated substances. The Comet-assay was carried out in a 12-well plate in $2 \mathrm{~mL}$ culture media containing $5 \%$ FBS, CB-MNvit was performed in QuadriPerm-dishes with $5 \mathrm{~mL}$ culture media containing 5\% FBS. Both assay protocols are described in detail by Könczöl et al. ${ }^{6}$

\section{Electrophoretic Mobility Shift Assay (EMSA)}

The influence of the particles on NF-kB DNA binding was determined by the electrophoretic mobility shift assay (EMSA). Further details are given elsewhere ${ }^{6}$ and in the Supporting Information.

\section{Western blot on JNK}

The influence of different particles on JNK was determined by Western blot analysis. Further details are given elsewhere ${ }^{6}$ and in the Supporting Information.

\section{Statistical Analysis}

Statistical analysis of bioassays was performed using SPSS Statistics (Version 17.0). All data presented are given as mean \pm standard deviation (SD) or standard error of mean (SE) of at least three independent experiments. Data shown for the Comet assay are mean $\mathrm{OTM} \pm \mathrm{SE}$ and tail intensity $[\%] \pm \mathrm{SE}$. For the CB-MNvit test, all data are expressed as mean $\pm \mathrm{SD}$ of MN/1000 BNC (ratio of micronuclei per 1000 binuclear cells). Statistical significance was assessed by one-way ANOVA followed by Dunnett's post hoc pairwise comparisons. A difference was considered significant at $\mathrm{P}<0.05$. 


\section{RESULTS}

\section{Particle Characterization}

SEM imaging (Fig. 1) revealed that the $\mathrm{CaSO}_{4}$ particles are irregularly shaped and typically 0.5-35 $\mu \mathrm{m}$ across. The $\mathrm{ZnSO}_{4} \cdot \mathrm{H}_{2} \mathrm{O}$ powder is composed of rounded particles ranging in size from 0.2 to $80 \mu \mathrm{m}$, whereas the $\mathrm{PbSO}_{4}$ sample contains mostly round to slightly elongated particles, which are 0.2-3 $\mu \mathrm{m}$ across and often present as agglomerates. Using the BSE imaging mode in combination with SEM-EDX analysis, we scanned approximately 100 particles in each of the three sulfate powders in search of possible contaminant phases. No such contaminant particles were detected in the $\mathrm{ZnSO}_{4} \cdot \mathrm{H}_{2} \mathrm{O}$ powder, and a few only occur in the $\mathrm{CaSO}_{4}$ powder (a Fe-Cr oxide, three Na-sulfate particles), implying that the samples are very pure. The $\mathrm{PbSO}_{4}$ powder, however, contains several $\mathrm{Al}_{2} \mathrm{O}_{3}$ particles in addition to a Nasulfate grain (data not shown).

The XRD patterns of the sulfates after a 4-h heat treatment at $180^{\circ} \mathrm{C}$ (Fig. 2) confirmed that 1) the Ca-sulfate powder is present as anhydrite $\left.\left(\mathrm{CaSO}_{4}\right) ; 2\right)$ the $\mathrm{Zn}$-sulfate powder is gunningite $\left(\mathrm{ZnSO}_{4} \cdot \mathrm{H}_{2} \mathrm{O}\right)$; and 3) the $\mathrm{Pb}$-sulfate powder is anglesite $\left(\mathrm{PbSO}_{4}\right)$. One of the difficulties encountered during our study is the pronounced hygroscopic behavior of gunningite, which can be transformed easily into other Zn-sulfate-hydrates depending on relative humidity (40). During the course of our study, the original gunningite (blue line in Fig. 2B) was indeed transformed partially into boyleite, a $\mathrm{Zn}$-sulfate-tetrahydrate $\left(\mathrm{ZnSO}_{4} \cdot 4 \mathrm{H}_{2} \mathrm{O}\right)$, as documented by the XRD pattern of a sample that was kept in a closed container for approximately 12 months after heat treatment (green line in Fig. 2B). Rietveld refinement of the XRD data for this sample revealed that the powder consisted of $79 \mathrm{wt} \%$ gunningite and $21 \mathrm{wt} \%$ boyleite. Therefore, all exposure experiments in A549 cells may have been performed with a mixture of gunningite and boyleite. Hence, in the paragraphs describing the exposure data, we will not 
specify the phase but use the general term Zn sulfate instead. The lower $\mathrm{Zn}$ content of the mixture due to the higher water content of boyleite is, however, minimal.

The XRD pattern of the $\mathrm{PbSO}_{4}$ sample contains additional peaks (Fig. 2C), which are caused by the presence of minor corundum $\left(\mathrm{Al}_{2} \mathrm{O}_{3}\right)$, a contaminant resulting from the milling process (abrasion product of our corundum micronizing mill). The presence of an $\mathrm{Al}$ phase in the $\mathrm{PbSO}_{4}$ sample was confirmed by the SEM observations and the AAS data. These data reveal that the milled and heated powder contains $1.52 \mathrm{wt} \% \mathrm{Al}$; on the other hand, no $\mathrm{Al}$ was detected in the original, non-milled powder (Table 1). Small amounts of $\mathrm{Al}$ (32 ppm) are also present in the $\mathrm{CaSO}_{4}$ powder, but not in the $\mathrm{Zn}$ sulfate sample. Other impurities have been detected as well, including some elements with known toxic potential, but their concentrations are low in all samples (Table 1).

The SEM observations related to size are in general agreement with the laser-diffraction data. All three metal-sulfate samples exhibit distinct maxima in their size distributions, in terms of both number and volume (Fig. 3 and Table 1S, Supporting information). Virtually all particles used for our cell-exposure experiments are $<2 \mu \mathrm{m}$ across (blue lines), and thus belong to the fine respirable fraction. Most abundant are particles with diameters of approximately $0.3,0.2$, 0.08, and $0.09 \mu \mathrm{m}$ (red lines) in the $\mathrm{CaSO}_{4}, \mathrm{ZnSO}_{4} \cdot \mathrm{H}_{2} \mathrm{O}, \mathrm{Zn}$ sulfate, and $\mathrm{PbSO}_{4}$ samples, respectively. Similarly, the maxima are also different in terms of the particle-volume distribution (black lines).

\section{Solubility of Sulfates in the Culture Medium}

The solubility product of gunningite in water at $25^{\circ} \mathrm{C}\left(\log K_{\mathrm{sp}}=-0.6\right)$ is substantially higher than that of anhydrite $\left(\log K_{\mathrm{sp}}=-4.2\right)$ and anglesite $\left(\log K_{\mathrm{sp}}=-7.9\right) \cdot{ }^{10}$ To find out to which extent the sulfates were dissolved in the culture medium, the metal concentrations in the culture medium at the experimental conditions $\left(37^{\circ} \mathrm{C}, \mathrm{pH}=7.4\right)$ were analyzed by AAS. 
Table 2 shows the concentrations of $\mathrm{Ca}, \mathrm{Zn}, \mathrm{Pb}$ and $\mathrm{Fe}$ in RPMI, in RPMI supplemented with $5 \%$ FBS, and in the supernatants of these metal-sulfate suspensions. These data were used for our thermodynamic modeling, which represents an essential basis for our interpretations (see discussion) because it predicts whether or not a specific phase precipitates from the RPMI culture medium or from the particle-containing culture medium solutions at $37^{\circ} \mathrm{C}$ and at $\mathrm{pH}$ 7.4 or at the lysosomal $\mathrm{pH}$ of 4.5 (Table $3 \mathrm{~S}$ Supporting Information).

\section{TEM Characterization of the Exposed Cells and Particle Uptake}

The TEM images in Figure 4 show intact A549 cells in the control sample, i.e. a sample that has not been exposed to any particles. A very similar appearance is also exhibited by the cells after exposure to $\mathrm{CaSO}_{4}$ particles, irrespective of particle concentration and duration of exposure (Fig. 1S in Supporting Information). After scanning 80-120 cells per sample, only one $\mathrm{CaSO}_{4}$ particle was detected in the cytoplasm of an A549 cell (Fig. 1SB in Supporting Information).

No Zn-sulfate particles were found in any of the investigated TEM samples. However, the A549 cells displayed morphological changes: after exposure to $\mathrm{Zn}$ sulfate for $24 \mathrm{~h}$, more than $80 \%$ of all studied cells show several vesicles (bright in TEM images, see Fig. 5). These vesicles are typically $0.15-1.8 \mu \mathrm{m}$ across (occasionally up to $3.2 \mu \mathrm{m}$ in diameter) and occur mostly on the cell surface, but also in the cytoplasm (Fig. 5). Furthermore, only cells that were exposed to the Zn-sulfate powder contain several rounded to slightly elongated dark vesicles. We therefore assume that these vesicles may be intracellular $\mathrm{Zn}$ pools, already described as zincosomes. ${ }^{49}$ They are smaller (0.3-0.5 $\mu \mathrm{m}$ across) and occur less frequently in cells exposed to $1 \mu \mathrm{g} / \mathrm{cm}^{2} \mathrm{Zn}$ sulfate (Fig. 5A, B) than in those exposed to a particle concentration of $10 \mu \mathrm{g} / \mathrm{cm}^{2}$ (Fig. 5C-F).

After exposing the A549 cells to $100 \mu \mathrm{g} / \mathrm{cm}^{2} \mathrm{PbSO}_{4}$ for $4 \mathrm{~h}$ (Fig. 6A, B), we observed vesicles that are mainlv 0.2-0.5 um in diameter and do not exceed $1 \mathrm{um}$. In contrast. the 
vesicles are larger $(0.5-0.8 \mu \mathrm{m})$ and much more abundant in cells that were exposed to $100 \mu \mathrm{g} / \mathrm{cm}^{2} \mathrm{PbSO}_{4}$ for $24 \mathrm{~h}$ (Fig 6C, D); some of these vesicles are elongated and may be as large as $4 \times 2 \mu \mathrm{m}$. The $\mathrm{PbSO}_{4}$ particles occur as either individual particles or agglomerates attached to the cell surface, free in the cytoplasm, or in vesicles (see Table 2S). After 4-h exposure, $\mathrm{PbSO}_{4}$ particles are present as subhedral to anhedral crystals (Fig. 6B), similar to the original material. After 24-h exposure, the $\mathrm{PbSO}_{4}$ particles have a needle-like to feathery appearance (Fig. 6D), and their TEM-EDX spectra show a small, but distinct Ca peak in addition to the characteristic $\mathrm{X}$-ray lines of $\mathrm{Pb}, \mathrm{S}$ and $\mathrm{O}$.

\section{Cytotoxicity}

Particles of $\mathrm{CaSO}_{4}$ did not cause any significant reduction of cell viability, neither in the WST-1 nor in the NR-uptake assay (Figs. 7, 8). For $\mathrm{PbSO}_{4}$, a reduction of cell viability was observed at $200 \mu \mathrm{g} / \mathrm{cm}^{2}$ in the WST-1 assay $(83 \%, \mathrm{p}<0.001)$ as well as in the NR-uptake assay $(83 \%$, not significant). Zinc sulfate showed a decreased viability for concentrations of 50 and $100 \mu \mathrm{g} / \mathrm{cm}^{2}$ in the WST-1 assay (Fig. 7), and of $\geq 25 \mu \mathrm{g} / \mathrm{cm}^{2}(61 \%, \mathrm{p}<0.01)$ in the NRuptake assay (Fig. 8). At concentrations of $50 \mu \mathrm{g} / \mathrm{cm}^{2}$, viability is reduced to $50 \%(\mathrm{p}<0.01$, WST-1) and $14 \%(\mathrm{p}<0.001, \mathrm{NR})$.

\section{ROS Production}

Since oxidative stress is known to influence cell viability, ROS formation induced by the three types of metal sulfates was assessed after different time points using the DCFH-DA assay. Interestingly, the data for $\mathrm{CaSO}_{4}$ display a concentration-dependent but inverse timedependent ROS formation (Fig. 9A). Highest levels of DCF fluorescence were observed after $2 \mathrm{~h}$ for $100 \mu \mathrm{g} / \mathrm{cm}^{2}$ (1.71-fold, $\left.\mathrm{p}<0.01\right)$ and $200 \mu \mathrm{g} / \mathrm{cm}^{2}$ (2.84-fold, $\left.\mathrm{p}<0.001\right)$. After 6 -h of exposure to $200 \mu \mathrm{g} / \mathrm{cm}^{2}$, ROS formation decreased to 1.59 -fold, reaching even lower levels after $24 \mathrm{~h}$ (1.31-fold), albeit not significant in either case. For $\mathrm{Zn}$ sulfate, both a 
concentration- and a time-dependent ROS production could be detected (Fig. 9B). Significantly increased ROS production was measured after $2 \mathrm{~h}$ at a concentration of 100 $\mu \mathrm{g} / \mathrm{cm}^{2}$ (1.65-fold, $\left.\mathrm{p}<0.05\right)$. After $6 \mathrm{~h}$, even stronger DCF fluorescence was observed for the lower concentrations (50 $\mu \mathrm{g} / \mathrm{cm}^{2}, 2.07$-fold), reaching a significant level at $100 \mu \mathrm{g} / \mathrm{cm}^{2}(4.50$ fold, $\mathrm{p}<0.01)$. After $24-\mathrm{h}$ exposure, ROS production increased already at $10 \mu \mathrm{g} / \mathrm{cm}^{2}(1.16-$ fold) and was pronounced at $25 \mu \mathrm{g} / \mathrm{cm}^{2}(2.23$-fold, $\mathrm{p}<0.05)$. Concentrations $>25 \mu \mathrm{g} / \mathrm{cm}^{2}$ were not tested due to cytotoxic effects (see Figs. 7, 8). After 2-h and 6-h exposure to $\mathrm{PbSO}_{4}$ particles, a significantly increased DCF fluorescence was only seen at $200 \mu \mathrm{g} / \mathrm{cm}^{2}(1.23$-fold, $\mathrm{p}<0.05 ; 1.81, \mathrm{p}<0.05)$. After $24 \mathrm{~h}$, a further increase of DCF fluorescence was observed (2.35fold, $\mathrm{p}<0.05)$.

The DCFH-DA assay is a valuable tool for measuring unspecific ROS formation. However, superoxide radicals do not react with the dye. ${ }^{50}$ Therefore, EPR analysis was performed to assess particle-induced superoxide formation in the A549 cells. After $24 \mathrm{~h}$, increased superoxide formation was observed for all substances tested, but for each of the metal sulfates, lower EPR signals were measured for the higher concentrations (Fig. 10). At $10 \mu \mathrm{g} / \mathrm{cm}^{2}$, for example, $\mathrm{CaSO}_{4}$ led to an increase compared to the untreated cells (2.4-fold), whereas at $100 \mu \mathrm{g} / \mathrm{cm}^{2}$, the EPR signal was only 1.8 times higher than that seen in the untreated cells. Similarly, exposure to $1 \mu \mathrm{g} / \mathrm{cm}^{2} \mathrm{Zn}$ sulfate caused a 2.5 -fold increase compared to the untreated control, whereas exposure to $10 \mu \mathrm{g} / \mathrm{cm}^{2}$ led to a 1.4 -fold increase only. For $\mathrm{PbSO}_{4}$, an increased superoxide formation was observed at $10 \mu \mathrm{g} / \mathrm{cm}^{2}$ (2.3-fold) and, to a smaller extent, at $100 \mu \mathrm{g} / \mathrm{cm}^{2}$ (1.8-fold).

\section{Mitochondrial Membrane Potential (MMP)}

We could show that all metal sulfates tested were able to increase ROS production in A549 cells. As mitochondria can be a vital and vulnerable target of reactive species we investigated changes of the MMP. After 24-h exposure of cells to the different metal sulfates, a moderate 
increase of JC-1 monomers, used as a marker of depolarization of the mitochondrial membrane, was observed for $\mathrm{Zn}$ sulfate $(5.5 \pm 3.3 \%)$ and $\mathrm{PbSO}_{4}(5.1 \pm 0.9 \%)$ compared to the untreated control $(2.8 \pm 0.9 \%)$. These values (Fig. 11), however, are very low compared to those produced by exposure of cells to the positive control valinomycin, where $34.8 \pm 8.5 \%$ $(\mathrm{p}<0.001)$ JC-1 monomers were measured.

\section{Induction of DNA Damage}

Oxidative stress is known to play a key role in particle-induced genotoxic effects. Therefore, we investigated the influence of the particle samples to cause DNA- or chromosome-damage. All metal sulfates induced DNA migration in a concentration-dependent manner after $4 \mathrm{~h}$ of exposure of A549 cells, as determined by the parameters OTM and Tail DNA (\%) in the comet assay (Fig. 12), although to a varying extent. A significantly increased DNA migration was observed for $\mathrm{CaSO}_{4}$ at $100 \mu \mathrm{g} / \mathrm{cm}^{2}(1.1 \pm 0.1 \mathrm{OTM}$; $\mathrm{p}<0.05)$, and a maximum was reached for $200 \mu \mathrm{g} / \mathrm{cm}^{2}(1.4 \pm 0.2 \mathrm{OTM}, \mathrm{p}<0.001)$ (Fig. 12A). The smallest increase was observed for $\mathrm{Zn}$ sulfate (Fig. 12B). Compared to the untreated control $(0.8 \pm 0.04$ OTM), $\mathrm{PbSO}_{4}$ showed a significant increase in OTM at $100 \mu \mathrm{g} / \mathrm{cm}^{2}(1.1 \pm 0.1$ OTM; $\mathrm{p}<0.05)$ (Fig. $12 \mathrm{C})$, with the highest value at $200 \mu \mathrm{g} / \mathrm{cm}^{2}(1.4 \pm 0.2 \mathrm{OTM}$; $<<0.001)$. The effects of all metal sulfates were less pronounced than those induced by the positive control $\mathrm{SiO}_{2}$ (Min-U-Sil 5, $\left.10 \mu \mathrm{g} / \mathrm{cm}^{2}\right)$.

\section{Induction of Micronuclei (MN) Formation}

The level of induced MN in A549 cells after 24-h exposure to the different metal sulfates is shown in Figure 13. The observed MN formation in binuclear cells (BNC) resulting from the treatment of the cells with culture medium only was 4 to $6 \mathrm{MN} / 1000 \mathrm{BNC}$. The positive control (EMS, $50 \mu \mathrm{M}$ ) induced $13.5 \pm 2.3 \mathrm{MN} / 1000 \mathrm{BNC}$ (Fig. 13).. $\mathrm{CaSO}_{4}$ exhibited a concentration-dependent increase for concentrations up to $50 \mu \mathrm{g} / \mathrm{cm}^{2}(10.6 \pm 3.0 \mathrm{MN} / 1000$; 
$\mathrm{p}<0.01)$, but a smaller effect was observed at $100 \mu \mathrm{g} / \mathrm{cm}^{2}(9.5 \pm 1.3 \mathrm{MN} / 1000 ; \mathrm{p}<0.05)$ (Fig. 13A). The most pronounced effects were observed for cells exposed to $\mathrm{Zn}$ sulfate, reaching a maximum of $27.5 \pm 3.9 \mathrm{MN} / 1000 \mathrm{BNC}$ at $10 \mu \mathrm{g} / \mathrm{cm}(\mathrm{p}<0.001)$ (Fig. 13B). In this case, an increase of $\mathrm{MN}$ formation was already noticed at $5 \mu \mathrm{g} / \mathrm{cm}^{2}(8.3 \pm 1.7 \mathrm{MN} / 1000)$. The weakest effect of all metal sulfates was observed for $\mathrm{PbSO}_{4}$, which induced a maximum of only $9.8 \pm$ 4.9 MN/1000 BNC (Fig. 13C). For both $\mathrm{CaSO}_{4}$ and $\mathrm{PbSO}_{4}$, CBPI revealed no inhibition of cell proliferation in any of the samples analyzed (see diamonds in Fig. 13A, C). For Zn sulfate, however, a concentration-dependent decrease of CBPI was observed (Fig. 13B, diamonds). For concentrations $>10 \mu \mathrm{g} / \mathrm{cm}^{2} \mathrm{Zn}$ sulfate, CBPI was $<1.5$, indicating inhibition of cell proliferation (data not shown).

\section{Cell Cycle}

The occurrence of DNA-damage activates the damage response pathway, consisting of various molecules acting as sensor, transducers and effectors, finally targeting the cell cycle. Effects of the tested metal sulfates on cell-cycle progression in A549 are shown in Figure 14. For $\mathrm{CaSO}_{4}$, no significant changes were observed at concentrations of 10 and $50 \mu \mathrm{g} / \mathrm{cm}^{2}$. Due to interferences with the assay system, concentrations higher than $50 \mu \mathrm{g} / \mathrm{cm}^{2}$ cannot be measured for $\mathrm{CaSO}_{4}$. Cell-cycle measurements in A549 cells after exposure to $25 \mu \mathrm{g} / \mathrm{cm}^{2} \mathrm{Zn}$ sulfate for $24 \mathrm{~h}$ revealed a dramatic increase in the percentage of cells in the G2 phase. In contrast, after exposure to $\mathrm{PbSO}_{4}$ a concentration-dependent increase of the sub-G1 subpopulation was observed, whereas the G1 and G2 peaks decreased concomitantly (Fig. 14).

\section{Influence on NF-KB and JNK}

Induction of oxidative stress can lead to subsequent activation of transcription factors or stress kinases. Therefore, effects on NF-kB and JNK activation were investigated. Exposure of 
A549 cells to $\mathrm{CaSO}_{4}$ increased NF- $\kappa B$ DNA binding activity at concentrations of $50 \mu \mathrm{g} / \mathrm{cm}^{2}$ (Fig. 15A). Lower or higher concentrations (10 and $100 \mu \mathrm{g} / \mathrm{cm}^{2}$, respectively) showed no effect on NF- $\mathrm{NB}$. Additional experiments were performed to analyze the effect of $\mathrm{CaSO}_{4}$ on $\mathrm{TNF} \alpha$-induced NF- $\kappa \mathrm{B}$ activation. Pretreatment with 10 to $50 \mu \mathrm{g} / \mathrm{cm}^{2}$ of $\mathrm{CaSO}_{4}$ particles and subsequent stimulation with $\mathrm{TNF} \alpha$ resulted in a strong NF- $\mathrm{KB}$ activation, comparable to, or even stronger than, that resulting from treatment with TNF $\alpha$ alone (see Fig. 15B). It is of note that pretreatment with $100 \mu \mathrm{g} / \mathrm{cm}^{2} \mathrm{CaSO}_{4}$ completely inhibited the TNF $\alpha$-induced NF- $\kappa \mathrm{B}$ activation.

To determine composition and identity of the formed NF-кB DNA complexes, a supershift analysis was performed. Accordingly, complex I from TNF $\alpha$-stimulated cells consists of p65 subunits, complex II of the heterodimer p50/p65, and complex III probably of p50 subunits (Fig. 15C). Interestingly, complex I of the particle-treated cells was only very slightly shifted by the antibody, indicating that this complex is composed of p65, but mainly of a not yet identified NF- $\mathrm{kB}$ subunit. The composition of complex II was identified as p50/p65, and complex III might be composed of p50.

The influence of $\mathrm{Zn}$ sulfate on NF- $\mathrm{kB}$ was measured for the non-cytotoxic concentrations of 5 and $10 \mu \mathrm{g} / \mathrm{cm}^{2}$ for 6,8 and $24 \mathrm{~h}$, respectively (Fig. 16A). At a concentration of $5 \mu \mathrm{g} / \mathrm{cm}^{2}$, a slight NF- $\mathrm{BB}$ activation was observed only after $8 \mathrm{~h}$ incubation, whereas $10 \mu \mathrm{g} / \mathrm{cm}^{2}$ were able

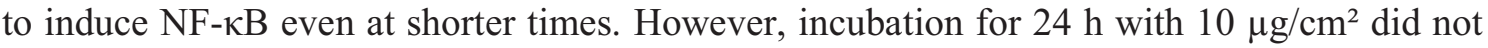
activate NF- $\kappa$ B. Treatment with $10 \mu \mathrm{g} / \mathrm{cm}^{2}$ led to the formation of an additional band (Fig. 16A, lanes 4 and 6).

To study the influence of ROS formation on NF- $\mathrm{BB}$ activation, the ROS scavengers butylated hydroxyanisol (BHA) and n-acetyl-cysteine (NAC) were used at different concentrations. For $10 \mu \mathrm{g} / \mathrm{cm}^{2} \mathrm{Zn}$ sulfate (exposure time: $6 \mathrm{~h}$ ), NAC was able to reduce the increased NF- $\mathrm{BB}$ 
DNA binding (complex I) to control level (compare lane 5 with lanes 9 and 10 in Fig. 16B), whereas BHA had no influence on NF-kB activation.

The EMSA experiment was also performed with equimolar concentrations of $\mathrm{ZnCl}_{2}$ to investigate whether the increase of NF-kB DNA binding activity is due to the $\mathrm{Zn}$ ions or the sulfate ions. It could be shown that $\mathrm{ZnCl}_{2}$ was also able to increase NF- $\kappa \mathrm{B}$ DNA binding at similar concentrations as $\mathrm{Zn}$ sulfate (data not shown) highlighting the role of zinc ions in NF$\kappa \mathrm{B}$ activation The influence of $\mathrm{PbSO}_{4}$ on the NF- $\kappa \mathrm{B}$ DNA binding activity was determined with exposure to $100 \mu \mathrm{g} / \mathrm{cm}^{2} \mathrm{PbSO}_{4}$ for 3 to $24 \mathrm{~h}$, but no detectable increase in NF- $\mathrm{BB}$ activation was observed (data not shown).

To determine the influence on $\mathrm{JNK}$, the $\mathrm{A} 549$ cells were treated with $\mathrm{CaSO}_{4}(10-$ $\left.100 \mu \mathrm{g} / \mathrm{cm}^{2}\right)$ and $\mathrm{Zn}$ sulfate $\left(5-25 \mu \mathrm{g} / \mathrm{cm}^{2}\right)$ for 12 and $24 \mathrm{~h}$ (Fig. 17). A combination of actinomycin D (333 nM) and TNFa $(4 \mathrm{ng} / \mathrm{mL})$ was used as a positive control, which caused a strong phosphorylation of JNK and an increase in total $\mathrm{JNK}$. The $\mathrm{CaSO}_{4}$ particles were not able to activate JNK at any of the tested concentrations and times (Fig. 17A). However, Zn sulfate at a concentration of $25 \mu \mathrm{g} / \mathrm{cm}^{2}$ activated JNK after 12 and $24 \mathrm{~h}$ as well as total JNK, but lower concentrations showed no effect (Fig. 17B). To determine the influence of ROS on Zn sulfate-induced JNK activation, the ROS scavenger NAC was added $1 \mathrm{~h}$ before particle treatment at concentrations ranging from 0.5 to $2 \mathrm{mM}$, and a reduction of JNK activation to control level was observed with 2 mM NAC (Fig. 2S, Supporting information). 


\section{DISCUSSION}

Numerous epidemiological studies have documented correlations between exposure to airborne PM of varying size and composition with adverse health effects, such as, cardiovascular or respiratory diseases, unscheduled admissions to hospitals, and increased morbidity and mortality. ${ }^{3,4}$ In this context, industrial PM is known to contribute notably to the composition of ambient PM..$^{7-9}$ In the present study, we carried out uptake experiments with three major anthropogenic components of PM, which were detected in a former study in stack emissions from a power station that combusted coal and a coal+tire mixture. ${ }^{10} \mathrm{We}$ also performed in-vitro biological investigations to evaluate the toxic potential of these particulates in A549 cells.

Sulfate uptake. Our TEM studies revealed no effect on the appearance of the A549 cells exposed to $\mathrm{CaSO}_{4}$ compared to the non-exposed cells. In our experiments, only one $\mathrm{CaSO}_{4}$ particle was found in the cytoplasm and none in vesicles. The AAS data showed that $\mathrm{CaSO}_{4}$ was dissolved in the culture medium to a considerable extent (Table 2), in agreement with our thermodynamic PHREEQC modeling, which predicts that the particle-containing culture medium is undersaturated with respect to $\mathrm{CaSO}_{4}$ and other $\mathrm{Ca}$ sulfates (e.g., gypsum) at the experimental conditions (Table 3S Supporting Information). We calculated that other $\mathrm{Ca}$ phases, however, may precipitate from this solution at $37^{\circ} \mathrm{C}$ and $\mathrm{pH} 7.4$, but dissolve under acidic conditions. Intracellular dissolution of Ca phases may also be driven by the formation of organic complexes, which is not included in the PHREEQC model. Since we observed biological effects after exposure of A549 cells to $\mathrm{CaSO}_{4}$, we conclude that the cellular response is caused by the $\mathrm{Ca}^{2+}$ released into the culture medium as a result of particle dissolution or, alternatively, is due to the uptake of particles and subsequent dissolution inside the cells.

No Zn-sulfate particles were observed in our TEM images, in agreement with our solubility experiments, which revealed that $\mathrm{Zn}$ sulfate dissolved to a large extent in the culture medium 
at a $\mathrm{pH}$ of 7.4 (Table 2). This is in accordance with our PHREEQC calculations, indicating that the particle suspensions are undersaturated with respect to $\mathrm{Zn}$-sulfate phases, but may precipitate other $\mathrm{Zn}$ phases, such as, $\mathrm{Zn}$ carbonate and $\mathrm{ZnO}$ at a $\mathrm{pH}$ of 7.4 (Table 3S, Supporting Information). At a lysosomal $\mathrm{pH}$ of 4.5, the particle-containing solution is undersaturated with respect to all considered $\mathrm{Zn}$ phases, i.e. they should not precipitate. However, a concentration-dependent increase in number and size of dark vesicles was observed (Fig. 5). Formation of these dark vesicles could be due to two possible mechanisms: 1) Zn-sulfate particles might have been engulfed by A549 cells and gradually dissolved in the acidic environment inside the endosomes, as observed previously for $\mathrm{ZnO} .^{35 ; 51 ; 52}$ 2) More likely, high amounts of $\mathrm{Zn}$ sulfate dissolved in the culture medium, as confirmed by our data (Table 2). The released $\mathrm{Zn}^{2^{+}}$ions have then been taken up by A549 cells, as described for $\mathrm{ZnO} .^{51 ; 53}$ After active uptake via zinc-iron related transporter proteins (ZIP), intracellular $\mathrm{Zn}$ transporter $(\mathrm{ZnT})$ and metallothionein-controlled $\mathrm{Zn}$ homeostasis led to sequestration of the $\mathrm{Zn}^{2^{+}}$into intracellular vesicles (zincosomes) and thus, were able to protect the cells from cytotoxic effects of $\mathrm{Zn}{ }^{49 ; 54}$ At a concentration of $10 \mu \mathrm{g} / \mathrm{cm}^{2} \mathrm{Zn}$ sulfate, the dark vesicles were larger and more abundant than at $1 \mu \mathrm{g} / \mathrm{cm}^{2}$, may indicating an augmented uptake and storage of $\mathrm{Zn}^{2^{+}}$. Vesicle swelling in A549 cells, a process confirmed by our TEM data (Fig. 5), may be a consequence of $\mathrm{Zn}$ overload and can lead to leakage of $\mathrm{Zn}^{2+}$ into the cytosol. ${ }^{53}$ Figure 5F may show the further development of these vesicles. At even higher concentrations, cell death occurred according to our bioassays.

Several individual particles of $\mathrm{PbSO}_{4}$ as well as agglomerates were observed in the cytoplasm or in vesicles (Fig. 6). However, the $\mathrm{PbSO}_{4}$ particles are much less abundant than the fine and ultrafine magnetite particles observed in A549 cells, which were exposed to similar concentrations. ${ }^{6}$ The TEM investigations revealed that in the sample exposed to $100 \mu \mathrm{g} / \mathrm{cm}^{2}$ $\mathrm{PbSO}_{4}$ for $4 \mathrm{~h}$, the $\mathrm{PbSO}_{4}$ particles exhibited sharp boundaries in both the vesicles and the cvtonlasm (Fig. 6B). In contrast. prolonged exnosure $(24 \mathrm{~h})$ seems to vield a different 
appearance and a different chemical composition of the $\mathrm{PbSO}_{4}$ particles: the latter show a needle-like habit and irregular grain boundaries (Fig. 6D) and, as documented by their EDX spectra, contain $\mathrm{Ca}$ in addition to the main components. This feature has not been observed in the other sulfate samples, suggesting that it is not an artifact that might have been caused by the contrasting medium used during sample preparation. Rather, it seems that the $\mathrm{PbSO}_{4}$ particles reacted with $\mathrm{Ca}$, which might be derived from the Ca-containing culture medium (Table 2). As expected for the $\mathrm{Pb}$-sulfate samples, $\mathrm{Al}_{2} \mathrm{O}_{3}$ crystals - resulting from the milling process in our corundum micronizing mill- were also observed (Table 2S, Supporting Information). According to literature data, however, $\mathrm{Al}_{2} \mathrm{O}_{3}$ particles do not induce considerable toxic effects in various cell lines for concentrations up to $62.5 \mu \mathrm{g} / \mathrm{cm}^{2}$ $(100 \mu \mathrm{g} / \mathrm{mL}),{ }^{55 ; 56}$ indicating that the effects we observed for $\mathrm{PbSO}_{4}$ should not be influenced by the presence of $\mathrm{Al}_{2} \mathrm{O}_{3}$ particles.

Cytotoxicity. Since mitochondria represent a vulnerable target for cytotoxicity testing of particulates, ${ }^{57}$ the WST-1 assay was chosen to assess this endpoint in A549 cells. Moreover, cytotoxicity was also determined by the NR assay to investigate different cellular answers and to evaluate possible cross-reactions between particles and assay components, which may lead to false-positive or -negative conclusions. ${ }^{58}$ The $\mathrm{CaSO}_{4}$ particles do not exhibit a pronounced cytotoxicity, as documented by the WST-1 and the NR assays (Fig. 7, 8). Furthermore, no impact on the MMP could be found (Fig. 11). $\mathrm{PbSO}_{4}$ was found to be slightly cytotoxic at the highest concentration tested $\left(200 \mu \mathrm{g} / \mathrm{cm}^{2}\right)$. The results of the WST-1 assay are consistent with MMP measurements (Fig. 11), where only a slightly increased mitochondrial depolarization was observed after exposure to $\mathrm{PbSO}_{4}$. Therefore, we suggest that the mitochondrial function in A549 is not affected by these particles. In contrast, exposure of A549 to Zn sulfate caused significant loss of cell viability (Figs. 7, 8). Comparison of the results from both cytotoxicity assays with those of the MMP measurements indicates that exposure to $\mathrm{Zn}$ sulfate affects the lvsosomal integritv before the mitochondria are damaged. This conclusion is sunnorted bv our 
TEM images, where exposure to $\mathrm{Zn}$ sulfate leads to occurrence of dark vesicles, which can have different appearances (Fig. 5). Furthermore, both size and number of these dark vesicles are concentration-dependent. Cytotoxic effects of $\mathrm{Zn}$ sulfate in A549 were found for similar concentrations in the sulphorhodamine B assay. ${ }^{59}$ The observed cytotoxic effects are most likely due to the $\mathrm{Zn}$ ions rather than the sulfate ions: this conclusion is supported by our additional cytotoxicity tests, which showed that $\mathrm{ZnCl}_{2}$, a readily soluble compound (Table $3 \mathrm{~S}$, Supporting Information), exhibited pronounced cytotoxic effects, even stronger than those caused by Zn sulfate (Fig 3S, Supporting information). Our results indicate that the increased ROS production (Fig. 9B), a slightly increased membrane depolarization (Fig. 11), JNKactivation (Fig. 17B), and a significant G2 arrest (Fig. 14) are involved in the observed cytotoxic effects. Special attention should be paid to the occurrence of vesicle swelling (Fig. 5C-E) after exposure of A549 to $10 \mu \mathrm{g} / \mathrm{cm}^{2} \mathrm{Zn}$ sulfate. Based on these observations, the following mechanism for $\mathrm{Zn}$ sulfate-mediated cellular response can be considered: after uptake, $\mathrm{Zn}^{2+}$ will probably be stored in zincosomes to maintain intracellular $\mathrm{Zn}$ homeostasis. ${ }^{60}$ Under physiological conditions, $\mathrm{Zn}$ release from metallothionein contributes to the normal progression of autophagy. High $\mathrm{Zn}^{2+}$ concentrations may lead to activation of excess autophagy, a process that could explain the appearance of dark vesicles and the concentrationdependent increase in vesicle number and size (see our TEM images in Fig. 5), and ultimately affect the membrane integrity of endosomes and vesicular Zn pools. ${ }^{61 ; 62}$ Rupture of the membrane results in rapid $\mathrm{Zn}^{2+}$ release and leakage of ROS and degrading enzymes, e.g. cathepsin and DNAse, into the cytoplasm, where it can induce cell death. ${ }^{63}$ Evidence for the proposed mechanism is given by Kao et al., who demonstrated recently that $\mathrm{Zn}^{2+}$ released from $\mathrm{ZnO}$ nanoparticles in endosomes interfered with $\mathrm{Zn}$ homeostasis, leading to destabilization of the endosomal membrane and cell death. ${ }^{64}$ In contrast, Buerki et al. suggested that $\mathrm{ZnO}$ toxicity in Jurkat cells is mediated by $\mathrm{Zn}^{2+}$ uptake of extracellularly dissolved particles. ${ }^{53}$ After all, both studies conclude that $\mathrm{Zn}^{2+}$ overload leads to disruption of 
Zn-containing vesicles, triggering cell death. According to our observations, we conclude that the onset of Zn-mediated cell death in A549 is triggered by excess autophagy due to deregulation of $\mathrm{Zn}$ homeostasis.

ROS production. An increasing number of studies on particle-mediated toxic effects identified oxidative stress as a key mechanism for consecutive cellular responses. In this study, the DCFH-DA assay was performed for measurement of unspecific ROS production and EPR for superoxide production in A549 cells. A concentration-dependent formation of ROS after exposure to $\mathrm{CaSO}_{4}$ was observed with the DCFH-DA assay after $2 \mathrm{~h}$ (Fig. 9A), but longer incubation periods led to a decline in the ROS levels in A549. For Zn sulfate, increased ROS levels were determined in a time- and concentration-dependent manner after $2 \mathrm{~h}$ (Fig. 9B), whereas exposure to high concentrations of $\mathrm{PbSO}_{4}$ resulted in increased ROS formation after $6 \mathrm{~h}$, with a further increase after $24 \mathrm{~h}$ incubation (Fig. 9C). Compared to the DCFH-DA assay, an increased superoxide formation was already observed for considerably lower concentrations of all sulfates tested by EPR (Fig. 10). Notably, this effect was smaller for higher concentrations. These regressive effects may have been induced by activation of the redox-sensitive transcription factor nrf2 and subsequent upregulation of cellular antioxidative mechanisms, such as, increased GSH level or SOD activity. ${ }^{65}$ As suggested in the previous section, ROS formation for Zn sulfate may be induced by endosomal disruption and increased $\mathrm{Zn}^{2+}$ release into the cytoplasm. It is known that deregulation of intracellular Ca homeostasis can trigger ROS formation, mitochondrial damage, and NF- $\mathrm{KB}$ activation. ${ }^{66 ; 67}$ Based on our WST-1 and MMP results for $\mathrm{CaSO}_{4}$, the participation of mitochondria may be excluded. As discussed in the section on sulfate uptake (see above), the $\mathrm{CaSO}_{4}$ particles were dissolved either in the culture medium or within the cells, after uptake. In addition, we observed a slight increase in NF-kB DNA binding activity after $6 \mathrm{~h}$ exposure to $50 \mu \mathrm{g} / \mathrm{cm}^{2}$ (Fig. 15A). The activation of NF- $\kappa \mathrm{B}$ might partly detoxify ROS via synthesis of antioxidant molecules like 
SOD or glutathione peroxidases, ${ }^{68}$ which would explain why the ROS production decreases parallel to NF-kB activation (6 h, see Fig. 9A).

Lead compounds are known to influence intracellular defense mechanisms ${ }^{26 ; 69}$ and to disturb Ca homeostasis. ${ }^{70}$ The increased superoxide level at low concentrations (Fig. 10) may be explained by the uptake of particles via phagocytosis, as shown by the TEM images (Fig. 6), leading to NOX activation. In addition, a reduced SOD activity could have resulted in retarded degradation and accumulation of superoxides, measured by EPR (Fig. 10). Higher $\mathrm{PbSO}_{4}$ concentrations were necessary to significantly increase ROS production in the DCFHDA assay (Fig. 9C). Since superoxides are barely analyzed with this assay, ${ }^{50}$ the retarded degradation of superoxide as well as depletion of GSH by reaction of $\mathrm{PbSO}_{4}$ with thiol groups might be responsible for these effects. ${ }^{69}$

Influence on signaling pathways. Since ROS are known to modulate the transcription factor

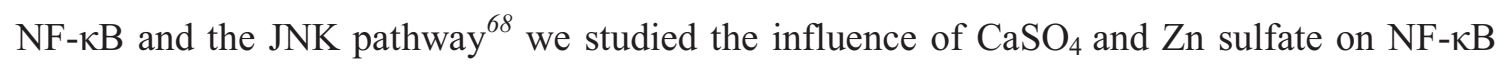
DNA binding activity and JNK activation with or without different ROS inhibitors. Since there is strong evidence that inflammatory lung diseases, such as asthma, can also be induced by inhaled particles, ${ }^{71-73}$ the influence of NF- $\mathrm{KB}$ in particle-associated lung diseases has been widely investigated..

For $\mathrm{CaSO}_{4}$ we observed an increase in NF- $\mathrm{BB}$ DNA binding activity after 6-h exposure to $50 \mu \mathrm{g} / \mathrm{cm}^{2}$ (Fig. 15A). Since we could not detect any loss in viability (Figs. 7, 8) nor significant ROS production for this concentration, the activation of NF- $\mathrm{kB}$ could possibly lead to a detoxification of ROS via synthesis of antioxidant molecules. ${ }^{68}$ For higher concentrations, no increase of NF- $\mathrm{kB}$ DNA binding activity but increased ROS formation can be observed, suggesting that the cellular antioxidative capacity may have been exhausted and other mechanisms activated. ${ }^{63} \mathrm{~A}$ direct link is known to exist between elevated intracellular Ca concentration and NF- $\mathrm{kB}$ activation. ${ }^{67}$ Brown et al. found that $\mathrm{nCB}$ were able to increase intracellular $\mathrm{Ca}$ concentrations, which in turn led to nuclear translocation of NF- $\mathrm{KB}$ and to an 
increase in TNF $\alpha$-protein level. ${ }^{32}$ These effects were reduced by adding the Ca-channel blocker verapamil and ROS inhibitors. In agreement with Brown et al. ${ }^{32}$ we observed an increase in DNA binding of the p50/p65 NF- $\mathrm{BB}$ subunit (Fig. 15C, II). However, the composition of the upper band (I) still remains unclear, as the band could not be shifted by the anti-p65 antibody. Additionally, pretreatment with $\mathrm{CaSO}_{4}\left(100 \mu \mathrm{g} / \mathrm{cm}^{2}\right)$ followed by stimulation with $\mathrm{TNF} \alpha$, simulating an acute inflammation, inhibited $\mathrm{TNF} \alpha$-induced NF- $\mathrm{KB}$ DNA binding, whereas no effect was observed for lower $\mathrm{CaSO}_{4}$ concentrations (Fig. 15B). In contrast to previous results obtained with magnetite nanoparticles, ${ }^{6}$ we did not observe a concentration-dependent reduction of NF- $\mathrm{KB}$ activation, but rather a threshold level of 100 $\mu \mathrm{g} / \mathrm{cm}^{2} \mathrm{CaSO}_{4}$, above which TNF $\alpha$ stimulation was not able to activate NF- $\kappa \mathrm{B}$. These results are in agreement with the study of Wong et al., who observed a diminished TNF $\alpha$-induced $\mathrm{NF}-\mathrm{\kappa B}$ activation in A549 cells after stress induction by heat shock or sodium arsenite. ${ }^{74}$ These stress responses increased the amount and inhibited the degradation of $\mathrm{I} \kappa \mathrm{B} \alpha$, which

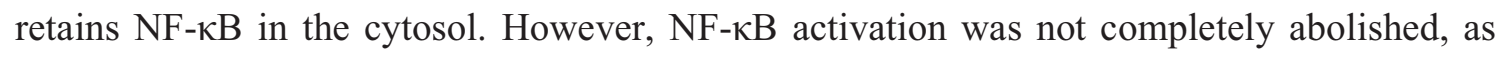
observed in our studies. Absorption of TNF $\alpha$ on the particle surface, as previously shown for $\mathrm{TNF} \alpha$ and IL-8 on $\mathrm{nCB},{ }^{75}$ could be excluded since there is no gradual reduction in TNF $\alpha$ stimulated NF- $\kappa B$ activation with increasing particle concentration.

For $\mathrm{Zn}$ sulfate, we observed an increase in NF- $\kappa \mathrm{B}$ DNA binding activity for the non-cytotoxic concentrations of 5 to $10 \mu \mathrm{g} / \mathrm{cm}^{2}$ (Fig. 16A). In HUT-78 cells Zn augmented NF- $\kappa$ B activation

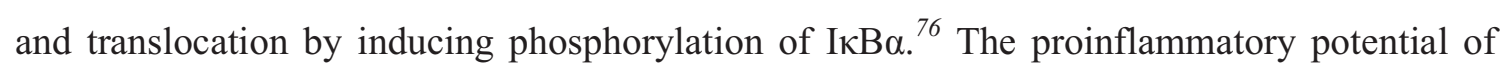
$\mathrm{Zn}^{2+}$ in PM has already been shown in several in-vivo studies. Kodavanti et al. correlated the inflammatory reaction in rats of respirable dusts with the amount of soluble $\mathrm{Zn}$ compounds, ${ }^{36}$ which was recently comfirmed by Cho et al. ${ }^{35}$ Intratracheal instillation of $\mathrm{Zn}$-containing dusts in mice also resulted in lung inflammation and fibrosis. ${ }^{77}$ For Zn-sulfate concentrations of 25 $\mu \mathrm{g} / \mathrm{cm}^{2}$, a sustained increase in $\mathrm{pJNK}$ and total JNK was found after $12 \mathrm{~h}$ (Fig. 17B). Kim et al. also observed a rapid phosphorylation of JNK at a concentration of $50 \mu \mathrm{M} \mathrm{ZnSO} \mathrm{Zn}_{4}$ in 
BEAS-2B cells, but already after a 15 -minute treatment. ${ }^{78}$ As sustained JNK activation leads to apoptosis, ${ }^{79}$ this mechanism could be one explanation for the cell death observed in the WST-1 and NR assays (Fig 7, 8), which started at $25 \mu \mathrm{g} / \mathrm{cm}^{2}$. Lower concentrations did not activate JNK but did activate NF-KB, which can negatively regulate JNK signaling by upregulating antiapoptotic genes. ${ }^{68}$

The experiments with different ROS scavengers showed that only NAC but not BHA reduced the NF- $\kappa$ B levels (Fig. 16B) and JNK activation (Fig. 2S, Supporting Information). These results could be explained either by trapping different kinds of $\operatorname{ROS}^{80 ; 81}$ or, more likely, by the ability of NAC to chelate $\mathrm{Zn}$ ions. ${ }^{53 ; 82}$

Genotoxicity and cell-cycle changes. For $\mathrm{CaSO}_{4}$, significant DNA-damage and $\mathrm{MN}$ induction was observed at $100 \mu \mathrm{g} / \mathrm{cm}^{2}$ in A549 (Figs. 12A, 13A). In contrast, Zhang et al. found no genotoxic effect after exposure of lymphoblasts to concentrations up to $140 \mu \mathrm{g} / \mathrm{cm}^{2}$ $\mathrm{CaSO}_{4}$ for $24 \mathrm{~h}^{83}$ Secondary genotoxicity can be excluded, since no persistent activation of NF- $\kappa \mathrm{B}$ occurred. It is more likely, that increased ROS formation after exposure of A549 cells to $\mathrm{CaSO}_{4}$ caused the genotoxic effects. Significantly increased ROS production was observed after $2 \mathrm{~h}$ at $100 \mu \mathrm{g} / \mathrm{cm}^{2}$ (Fig. 9A), whereas the Comet assay revealed genotoxic effects after 4 h. However, for $100 \mu \mathrm{g} / \mathrm{cm}^{2}$ no increase in DCF fluorescence could be observed after $24 \mathrm{~h}$ (Fig. 9A), but superoxide level (Fig. 10) and MN formation (Fig. 13A) increased at this timepoint. Radicals may have damaged DNA by direct oxidative attack or indirectly by peroxidation of proteins and lipids. ${ }^{84}$ Kibanova et al. noticed an increased LPO after exposure of rat brain homogenates to $\mathrm{CaO}$ and $\mathrm{CaCl}_{2}{ }^{85}$ In our experiments, exposure of $\mathrm{A} 549$ to $\mathrm{CaSO}_{4}$ did not increase LPO level, measured as MDA with TBARS assay (data not shown). Summarizing the present data, we conclude that after $\mathrm{CaSO}_{4}$-mediated ROS formation the oxidation of the DNA may lead to the observed genotoxic effects. Interestingly, these effects do not influence the cell cycle of A549 cells (Fig. 14). The analysis of the cell cycle- 
associated proteins p53 and p21 supported these observations, as $\mathrm{CaSO}_{4}$ did not trigger upregulation of these proteins (see supporting information, Fig. 5S).

Radical production could have caused the concentration-dependent genotoxic effects measured for $\mathrm{Zn}$ sulfate after $4 \mathrm{~h}$ by direct attack of the DNA. However, another indirect mechanism was elucidated recently by Sliwinski et al., who demonstrated that increased ROS production after exposure to $\mathrm{ZnSO}_{4}$ diminished DNA repair in K562 leukemia cells. ${ }^{39}$ Our results obtained from the CB-MNvit should clarify, whether or not DNA damage caused by exposure to $\mathrm{Zn}$ sulfate could lead to chromosomal damage. A significant $\mathrm{MN}$ induction was observed for $10 \mu \mathrm{g} / \mathrm{cm}^{2}$ of $\mathrm{Zn}$ sulfate in A549 with concomitant decrease of the CBPI, implying that cell proliferation is reduced (Fig. 13B). In fact, cell-cycle experiments revealed that A549 cells are arrested in the G2 phase (Fig. 14) only after exposure to $25 \mu \mathrm{g} / \mathrm{cm}^{2}$ of $\mathrm{Zn}$ sulfate. However, this can be explained by a different volume : surface ratio in the CB-MNvit assay and the solubility of $\mathrm{Zn}$ sulfate depending on the volume of the culture medium, leading to different molarities. Since the CB-MNvit is performed on microscope slides $\left(19.7 \mathrm{~cm}^{2}\right)$, a concentration of $10 \mu \mathrm{g} / \mathrm{cm}^{2}(39.5 \mu \mathrm{g} / \mathrm{mL})$ in the CB-MNvit corresponds more to $25 \mu \mathrm{g} / \mathrm{cm}^{2}$ (40.0 $\mu \mathrm{g} / \mathrm{mL}$ ) in the other well formats. We therefore suggest that the high $\mathrm{MN}$ induction observed does not reflect an intrinsic mutagenicity of $\mathrm{Zn}$ sulfate, but may be due to its cytotoxic potential. In summary, the $\mathrm{Zn}$ sulfate-induced G2 arrest is mediated by DNA damage due to increased cytotoxicity.

The results of the Comet assay revealed increased DNA damage after $4 \mathrm{~h}$ (Fig. 12C), and MN frequency was slightly higher after $24 \mathrm{~h}$ (Fig. 13C). A decreased DNA-repair capacity after exposure to $\mathrm{Pb}$ compounds was observed recently. ${ }^{86 ; 87} \mathrm{We}$ therefore suggest that DNA-repair mechanisms could have preventive activity in manifestation of clastogen events for submillimolar concentrations of $\mathrm{PbSO}_{4}$ after $24 \mathrm{~h} .{ }^{15}$ However, for soluble $\mathrm{Pb}$ compounds, $\mathrm{MN}$ formation in V79 cells increased at concentrations of $0.3 \mu \mathrm{M} \mathrm{Pb}^{2+} .{ }^{25}$ The authors could show that interactions between $\mathrm{Pb}$ ions and components of the cytoskeleton may be responsible for 
these effects. According to the concentration of $100 \mu \mathrm{g} / \mathrm{cm}^{2} \mathrm{PbSO}_{4}$ in culture media $(8.06 \mu \mathrm{M}$ $\left.\mathrm{Pb}^{2+}\right), \mathrm{Pb}$ ions may also react with microtubules in our experiments, thus contributing to the observed cytogenetic effects. Interestingly, the analysis of the cell cycle revealed a significant increase of the sub-G1 population (Fig. 14). An increased sub-G1 peak is often associated with necrotic or apoptotic events. However, caspase 3/7-activity increased only slightly after $\mathrm{PbSO}_{4}$ treatment (see supporting information, Fig. 4S). Furthermore, cell cycle-related proteins p53 and p21 were found to be upregulated (see supporting information, Fig. 5S). We therefore assume that the observed genotoxic effects lead to activation of p53 and p21 and induced a cell cycle arrest in Sub-G1 phase rather than cell death. A Sub-G1 arrest was recently reported for microtubule stabilization drugs, ${ }^{88 ; 89}$ which would be in agreement with the aforementioned ability of $\mathrm{Pb}$ to interact with components of the cytoskeleton. However, this possible interaction requires further studies.

In summary, this study again underlines the importance of a thorough mineralogical characterization combined with detailed investigations on toxic effects and signaling pathways to elucidate the underlying particle-specific mechanisms on in-vitro based cell models. Since almost all of the particles tested are $<2 \mu \mathrm{m}$ in diameter, the observed effects give rise to concern if considerable amounts of these compounds can be found in the environment. In our experiments, A549 cells were exposed to concentrations up to $200 \mu \mathrm{g} / \mathrm{cm}^{2}$, in order to investigate biological effects and their underlying mechanisms. Although these concentrations used in this in vitro study may not reflect realistic exposure scenarios, higher concentrations may be reached by accumulation of particles or "hot spots" in the lung. For assessing the long-term risk for human exposure, further studies on quantitative exposure (biomonitoring) and on bio-effect monitoring are needed.

\section{Acknowledgements}


We thank Robert Burzan for assistance with the Comet assay, as well as Dr. Andreas Danilewsky, Angela Thiemann, Isolde Schmidt and Sigrid Hirth-Walther from the Institute of Geosciences at the University of Freiburg for their invaluable help with SEM, laser diffraction, XRD and AAS analysis. 


\section{Reference List}

(1) WHO (2004) Health aspects of air pollution. Results from the WHO project "Systematic review of health aspects of air pollution in Europe", Kopenhagen, Denmark.

(2) Brook, R. D., Rajagopalan, S., Pope, C. A., Brook, J. R., Bhatnagar, A., ez-Roux, A. V., Holguin, F., Hong, Y. L., Luepker, R. V., Mittleman, M. A., Peters, A., Siscovick, D., Smith, S. C., Whitsel, L., and Kaufman, J. D. (2010) Particulate Matter Air Pollution and Cardiovascular Disease. An Update to the Scientific Statement From the American Heart Association. Circulation 121(21), 2331-2378.

(3) Pelucchi, C., Negri, E., Gallus, S., Boffetta, P., Tramacere, I., and La Vecchia, C. (2009) Long-term particulate matter exposure and mortality: a review of European epidemiological studies. Bmc Public Health 9, 453.

(4) Peters, A., Wichmann, H. E., Tuch, T., Heinrich, J., and Heyder, J. (1997) Respiratory effects are associated with the number of ultrafine particles. Am. J. Respir. Crit. Care Med. 155(4), 1376-1383.

(5) Gminski, R., Decker, K., Heinz, C., Seidel, A., Könczöl, M., Goldenberg, E., Grobéty, B., Ebner, W., Gieré, R., and Mersch-Sundermann, V. (2011) Genotoxic Effects of Three Selected Black Toner Powders and Their Dimethyl Sulfoxide Extracts in Cultured Human Epithelial A549 Lung Cells In Vitro. Environ. Mol. Mutagen. 52(4), 296-309.

(6) Könczöl, M., Ebeling, S., Goldenberg, E., Treude, F., Gminski, R., Gieré, R., Grobéty, B., Rothen-Rutishauser, B., Merfort, I., and Mersch-Sundermann, V. (2011) Cytotoxicity and Genotoxicity of Size-Fractionated Iron Oxide (Magnetite) in A549 Human Lung Epithelial Cells: Role of ROS, JNK, and NF-kB. Chem. Res. Toxicol. 24(9), 14601475.

(7) Donaldson, K., Tran, L., Jimenez, L. A., Duffin, R., Newby, D. E., Mills, N., MacNee, W., and Stone, V. (2005) Combustion-derived nanoparticles: a review of their toxicology following inhalation exposure. Part. Fibre Toxicol. 2.

(8) Gieré, R., and Querol, X. (2010) Solid Particulate Matter in the Atmosphere. Elements 6(4), 215-222.

(9) Grobéty, B., Gieré, R., Dietze, V., and Stille, P. (2010) Airborne Particles in the Urban Environment. Elements 6(4), 229-234.

(10) Gieré, R., Blackford, M., and Smith, K. (2006) TEM Study of PM2.5 Emitted from Coal and Tire Combustion in a Thermal Power Station. Environ. Sci. Technol. 40(20), 62356240 .

(11) Jablonska, M., Rietmeijer, F. J. M., and Janeczek, J. (2001) Fine-grained barite in coal fly ash from the Upper Silesian Industrial Region. Environ. Geol. 40(8), 941-948.

(12) Engelbrecht, J.P., and Derbyshire, E. (2010) Airborne mineral dust. Elements 6(4), 241-246. 
(13) Twining, J., McGlinn, P., Loi, E., Smith, K., and Gieré, R. (2005) Risk ranking of bioaccessible metals from fly ash dissolved in simulated lung and gut fluids. Environ. Sci. Technol. 39(19), 7749-7756.

(14) IARC (2006) Inorganic and Organic lead Compounds. IARC Monogr Eval Carcinog Risks Hum 87.

(15) Wozniak, K., and Blasiak, J. (2003) In vitro genotoxicity of lead acetate: induction of single and double DNA strand breaks and DNA-protein cross-links. Mutat. Res.- Gen. Tox. En. 535(2), 127-139.

(16) Palus, J., Rydzynski, K., Dziubaltowska, E., Wyszynska, K., Natarajan, A. T., and Nilsson, R. (2003) Genotoxic effects of occupational exposure to lead and cadmium. Mutat. Res.Gen. Tox. En. 540(1), 19-28.

(17) Grover, P., Rekhadevi, P. V., Danadevi, K., Vuyyuri, S. B., Mahboob, M., and Rahman, M. F. (2010) Genotoxicity evaluation in workers occupationally exposed to lead. Int. J. Hyg. Environ. Health 213(2), 99-106.

(18) Uzu, G., Sauvain, J. J., Baeza-Squiban, A., Riediker, M., Sanchez Sandoval Hohl, M., Val, S., Tack, K., Denys, S., Pradère, P., and Dumat, C. (2011) In vitro Assessment of the Pulmonary Toxicity and Gastric Availability of Lead-Rich Particles from a Lead Recycling Plant. Environ. Sci. Technol. 45(18), 7888-7895.

(19) Gurer, H., and Ercal, N. (2000) Can antioxidants be beneficial in the treatment of lead poisoning? Free Rad. Biol.Med. 29(10), 927-945.

(20) Gurer-Orhan, H., Sabir, H. U., and Ozgunes, H. (2004) Correlation between clinical indicators of lead poisoning and oxidative stress parameters in controls and leadexposed workers. Toxicology 195(2-3), 147-154.

(21) Sammut, M. L., Noack, Y., Rose, J., Hazemann, J. L., Proux, O., Depoux, M., Ziebel, A., and Fiani, E. (2010) Speciation of $\mathrm{Cd}$ and $\mathrm{Pb}$ in dust emitted from sinter plant. Chemosphere 78(4), 445-450.

(22) Ettler, V., Johan, Z., Baronnet, A., Jankovsky, F., Gilles, C., Mihaljevic, M., Sebek, O., Strnad, L., and Bezdicka, P. (2005) Mineralogy of air-pollution-control residues from a secondary lead smelter: Environmental implications. Environ. Sci. Technol. 39(23), 9309-9316.

(23) Czaplicka, M., and Buzek, L. (2011) Lead Speciation in the Dusts Emitted from Non-Ferrous Metallurgy Processes. Water, Air, Soil Pollut. 218(1-4), 157-163.

(24) Uzu, G., Sobanska, S., Sarret, G., Sauvain, J. J., Pradère, P., and Dumat, C. (2011) Characterization of lead-recycling facility emissions at various workplaces: Major insights for sanitary risks assessment. J. Hazard. Mat. 186(2-3), 1018-1027.

(25) Bonacker, D., Stoiber, T., Bohm, K. J., Prots, I., Wang, M. S., Unger, E., Thier, R., Bolt, H. M., and Degen, G. H. (2005) Genotoxicity of inorganic lead salts and disturbance of microtubule function. Environ. Mol. Mutagen. 45(4), 346-353. 
(26) Hernandez-Franco, P., Silva, M., Valverde, M., and Rojas, E. (2011) Induction of oxidative stress by low doses of lead in human hepatic cell line WRL-68. BioMetals 24(5), 951958.

(27) Dockery, D. W., Pope, C. A., Xu, X. P., Spengler, J. D., Ware, J. H., Fay, M. E., Ferris, B. G., and Speizer, F. E. (1993) An Association Between Air-Pollution and Mortality in 6 United-States Cities. N. Eng. J. Med. 329(24), 1753-1759.

(28) Schlesinger, R. B. (2007) The health impact of common inorganic components of fine particulate matter (PM2.5) in ambient air: A critical review. Inhal. Toxicol. 19(10), 811-832.

(29) Dopp, E., Yadav, S., Ansari, F. A., Bhattacharya, K., von Recklinghausen, U., Rauen, U., Rodelsperger, K., Shokouhi, B., Geh, S., and Rahman, Q. (2005) ROS-mediated genotoxicity of asbestos-cement in mammalian lung cells in vitro. Part. Fibre Toxicol. 2 .

(30) Geh, S., Yücel, R., Duffin, R., Albrecht, C., Borm, P., Armbruster, L., Raulf-Heimsoth, M., Brüning, T., Hoffmann, E., Rettenmeier, A., and Dopp, E. (2006) Cellular uptake and cytotoxic potential of respirable bentonite particles with different quartz contents and chemical modifications in human lung fibroblasts. Arch. Toxicol. 80(2), 98-106.

(31) Berridge, M. J., Bootman, M. D., and Roderick, H. L. (2003) Calcium signalling: Dynamics, homeostasis and remodelling. Nat. Rev. Mol. Cell Biol. 4(7), 517-529.

(32) Brown, D. M., Donaldson, K., Borm, P. J., Schins, R. P., Dehnhardt, M., Gilmour, P., Jimenez, L. A., and Stone, V. (2004) Calcium and ROS-mediated activation of transcription factors and TNF-alpha cytokine gene expression in macrophages exposed to ultrafine particles. Am. J. Physiol.- Lung Cell. Mol. Physiol. 286(2), L344L353.

(33) Institute of Medicine, Food and Nutrition Board (2001) Dietary Reference Intakes for Vitamin A, Vitamin K, Arsenic, Boron, Chromium, Copper, Iodine, Iron, Manganese, Molybdenum, Nickel, Silicon, Vanadium, and Zinc. National Academy Press, Washington DC.

(34) Gordon, T., Chen, L. C., Fine, J. M., Schlesinger, R. B., Su, W. Y., Kimmel, T. A., and Amdur, M. O. (1992) Pulmonary Effects of Inhaled Zinc-Oxide in Human-Subjects, Guinea-Pigs, Rats, and Rabbits. Am. Ind. Hyg. Assoc. J. 53(8), 503-509.

(35) Cho, W. S., Duffin, R., Howie, S., Scotton, C., Wallace, W., MacNee, W., Bradley, M., Megson, I., and Donaldson, K. (2011) Progressive severe lung injury by zinc oxide nanoparticles; the role of $\mathrm{Zn}^{2+}$ dissolution inside lysosomes. Part. Fibre Toxicol. 8(1), 27.

(36) Kodavanti, U. P., Schladweiler, M. C. J., Ledbetter, A. D., Hauser, R., Christiani, D. C., Samet, J. M., Mcgee, J., Richards, J. H., and Costa, D. L. (2002) Pulmonary and systemic effects of zinc-containing emission particles in three rat strains: Multiple exposure scenarios. Toxicol. Sci. 70(1), 73-85. 
(37) Hackenberg, S., Scherzed, A., Technau, A., Kessler, M., Froelich, K., Ginzkey, C., Koehler, C., Burghartz, M., Hagen, R., and Kleinsasser, N. (2011) Cytotoxic, genotoxic and pro-inflammatory effects of zinc oxide nanoparticles in human nasal mucosa cells in vitro. Toxicol. In Vitro 25(3), 657-663.

(38) Sharma, V., Singh, S. K., Anderson, D., Tobin, D. J., and Dhawan, A. (2011) Zinc Oxide Nanoparticle Induced Genotoxicity in Primary Human Epidermal Keratinocytes. $J$. Nanosci. Nanotechnol. 11(5), 3782-3788.

(39) Sliwinski, T., Czechowska, A., Kolodziejczak, M., Jajte, J., Wisniewska-Jarosinska, M., and Blasiak, J. (2009) Zinc salts differentially modulate DNA damage in normal and cancer cells. Cell Biol. Int. 33(4), 542-547.

(40) Chou, I. M., and Seal II, R. R. (2005) Determination of goslarite-bianchite equilibria by the humidity-buffer technique at 0.1 MPa. Chem. Geol. 215, 517-523.

(41) Cheary, R. W., and Coelho, A. A. (1992) A fundamental parameters approach to x-ray lineprofile fitting. J. Appl.Crystallogr. 25, 109-121.

(42) Anthony, J. W., Bideaux. R.A., Bladh, K.W., Nichols, M.C. (2003) Handbook of Mineralogy, Volume V: Borates, Carbonates, Sulfates. Mineralogical Society of America.

(43) Parkhurst, D. L. and Appelo, C. A. J. (1999) PHREEQC . US Geological Survey Retrieved 22 December 2011. Available from http://wwwbrr.cr.usgs.gov.

(44) Lieber, M., Smith, B., Szakal, A., Nelson-Rees, W., and Todaro, G. (1976) A continuous tumor-cell line from a human lung carcinoma with properties of type II alveolar epithelial cells. Int. J. Cancer 17(1), 62-70.

(45) Harrington, AD.; Tsirka, SE.; and Schoonen MA. (2012) Quantification of particle-induced inflammatory stress response: a novel approach for toxicity testing of earth materials. Geochem Trans. 13, 4.

(46) Zhao, Y., Yang, G., Ren, D., Zhang, X., Yin, Q., and Sun, X. (2010) Luteolin suppresses growth and migration of human lung cancer cells. Mol. Biol. Rep. 38(2), 1115-1119.

(47) OECD (2010) Test No. 487: In Vitro Mammalian Cell Micronucleus Test (MNvit), OECD Guidelines for Testing of Chemicals ,OECD, Paris, France.

(48) Fenech, M. (2007) Cytokinesis-block micronucleus cytome assay. Nat. Protoc. 2(5), 10841104.

(49) Beyersmann, D., and Haase, H. (2001) Functions of zinc in signaling, proliferation and differentiation of mammalian cells. BioMetals 14(3-4), 331-341.

(50) Zhu, H., Bannenberg, G. L., Moldeus, P., and Shertzer, H. G. (1994) Oxidation Pathways for the Intracellular Probe 2',7'-Dichlorofluorescin. Arch. Toxicol. 68(9), 582-587.

(51) Xia, T., Kovochich, M., Liong, M., Madler, L., Gilbert, B., Shi, H. B., Yeh, J. I., Zink, J. I., and Nel, A. E. (2008) Comparison of the Mechanism of Toxicity of Zinc Oxide and 
Cerium Oxide Nanoparticles Based on Dissolution and Oxidative Stress Properties. Acs Nano 2(10), 2121-2134.

(52) Müller, H.K., Kulkarni, J., Motskin, M., Goode, A., Winship, P., Skepper, J.N., Ryan, M.P., Porter, A.E. (2010) pH-Dependent Toxicity of High Aspect Ratio ZnO Nanowires in Macrophages Due to Intracellular Dissolution. Acs Nano, 4(11), 6767-6779.

(53) Buerki-Thurnherr, T., Xiao, L., Diener, L., Arslan, O., Hirsch, C., Maeder-Althaus, X., Grieder, K., Wampfler, B., Mathur, S., Wick, P., and Krug, H. F. (2012) In vitro mechanistic study towards a better understanding of $\mathrm{ZnO}$ nanoparticle toxicity. Nanotoxicology, 1-15.

(54) Lopez, V., Foolad, F., and Kelleher, S. L. (2011) ZnT2-overexpression represses the cytotoxic effects of zinc hyper-accumulation in malignant metallothionein-null T47D breast tumor cells. Cancer Lett. 304(1), 41-51.

(55) Jeng, H. A., and Swanson, J. (2006) Toxicity of metal oxide nanoparticles in mammalian cells. J. Environ. Sci. Health, Part A: Toxic/Hazard. Subst. Environ. Eng. 41(12), 2699-2711.

(56) Schrand, A. M., Rahman, M. F., Hussain, S. M., Schlager, J. J., Smith, D. A., and Syed, A. F. (2010) Metal-based nanoparticles and their toxicity assessment. Wiley Interdiscip. Rev.- Nanomed. Nanobiotechnol. 2(5), 544-568.

(57) Xia, T., Kovochich, M., and Nel, A. E. (2007) Impairment of mitochondrial function by particulate matter (PM) and their toxic components: implications for PM-induced cardiovascular and lung disease. Front. Biosci. 12, 1238-1246.

(58) Krug, H. K., and Wick, P. (2011) Nanotoxicology: An Interdisciplinary Challenge. Angew. Chem., Int. Ed. 50(6), 1260-1278.

(59) Lin, W. S., Xu, Y., Huang, C. C., Ma, Y. F., Shannon, K. B., Chen, D. R., and Huang, Y. W. (2009) Toxicity of nano- and micro-sized $\mathrm{ZnO}$ particles in human lung epithelial cells. J. Nanopart. Res. 11(1), 25-39.

(60) Lichten, L. A., and Cousins, R. J. (2009) Mammalian Zinc Transporters: Nutritional and Physiologic Regulation. Annu. Rev. Nutr. 29, 153-176.

(61) Lee, S. J., and Koh, J. Y. (2010) Roles of zinc and metallothionein-3 in oxidative stressinduced lysosomal dysfunction, cell death, and autophagy in neurons and astrocytes. Mol. brain 3(1), 30 .

(62) Hwang, J. J., Lee, S. J., Kim, T. Y., Cho, J. H., and Koh, J. Y. (2008) Zinc and 4-Hydroxy-2Nonenal Mediate Lysosomal Membrane Permeabilization Induced by $\mathrm{H}_{2} \mathrm{O}_{2}$ in Cultured Hippocampal Neurons. J. Neurosci. 28(12), 3114-3122.

(63) Kroemer, G., and Jaattela, M. (2005) Lysosomes and autophagy in cell death control. Nat. Rev. Cancer 5(11), 886-897. 
(64) Kao, Y. Y., Chen, Y. C., Cheng, T. J., Chiung, Y. M., and Liu, P. S. (2012) Zinc Oxide Nanoparticles Interfere With Zinc Ion Homeostasis to Cause Cytotoxicity. Toxicol. Sci. 125(2), 462-472.

(65) Nel, A., Xia, T., Madler, L., and Li, N. (2006) Toxic potential of materials at the nanolevel. Science 311(5761), 622-627.

(66) Ermak, G., and Davies, K. J. A. (2002) Calcium and oxidative stress: from cell signaling to cell death. Mol. Immunol. 38(10), 713-721.

(67) Hughes, K., Antonsson, A., and Grundstrom, T. (1998) Calmodulin dependence of NF kappa B activation. Febs Lett. 441(1), 132-136.

(68) Bubici, C., Papa, S., Dean, K., and Franzoso, G. (2006) Mutual cross-talk between reactive oxygen species and nuclear factor-kappa B: molecular basis and biological significance. Oncogene 25(51), 6731-6748.

(69) Ahamed, M., and Siddiqui, M. K. J. (2007) Low level lead exposure and oxidative stress: Current opinions. Clin. Chim. Acta 383(1-2), 57-64.

(70) Pounds, J. G. (1984) Effect of Lead-Intoxication on Calcium Homeostasis and CalciumMediated Cell-Function - A Review. Neurotoxicology 5(3), 295-331.

(71) O'Dea, E., and Hoffmann, A. (2009) NF-kappa B signaling. Wiley Interdiscip. Rev.- Syst. Biol. Med. 1(1), 107-115.

(72) Janssen-Heininger, Y. M. W., Poynter, M. E., Aesif, S. W., Pantano, C., Ather, J. L., Reynaert, N. L., Ckless, K., Anathy, V., van der Velden, J., Irvin, C. G., and van der Vliet, A. (2009) Nuclear factor kappaB, airway epithelium, and asthma: avenues for redox control. Proc. Am. Thorac. Soc. 6(3), 249-255.

(73) Schins, R. P. F., and Donaldson, K. (2000) Nuclear factor Kappa-B activation by particles and fibers. Inhal. Toxicol. 12, 317-326.

(74) Churg, A., Xie, C. S., Wang, X. S., Vincent, R., and Wang, R. D. (2005) Air pollution particles activate NF-kappa B on contact with airway epithelial cell surfaces. Toxicol. Appl. Pharmacol. 208(1), 37-45.

(75) Brown, D. M., Dickson, C., Duncan, P., Al-Attili, F., and Stone, V. (2010) Interaction between nanoparticles and cytokine proteins: impact on protein and particle functionality. Nanotechnology 21(21).

(76) Bao, B., Prasad, A. S., Beck, F. W. J., and Sarkar, F. H. (2007) Zinc up-regulates NF-kappaB activation via phosphorylation of IkappaB in HUT-78 (Th0) cells. Febs Lett. 581(23), 4507-4511.

(77) Adamson, I. Y. R., Prieditis, H., Hedgecock, C., and Vincent, R. (2000) Zinc Is the Toxic Factor in the Lung Response to an Atmospheric Particulate Sample. Toxicol. Appl. Pharmacol. 166(2), 111-119. 
(78) Kim, Y. M., Reed, W., Wu, W. D., Bromberg, P. A., Graves, L. M., and Samet, J. M. (2006) $\mathrm{Zn}^{2+}$-induced IL-8 expression involves AP-1, JNK, and ERK activities in human airway epithelial cells. Am. J. Physiol.- Lung Cell. Mol. Physiol. 290(5), 1028-1035.

(79) Chen, Y. R., and Tan, T. H. (2000) The c-Jun N-terminal kinase pathway and apoptotic signaling (review). Int. J. Oncol. 16(4), 651-662.

(80) Festjens, N., Kalai, M., Smet, J., Meeus, A., Van Coster, R., Saelens, X., and Vandenabeele, P. (2005) Butylated hydroxyanisole is more than a reactive oxygen species scavenger. Cell Death Differ. 13(1), 166-169.

(81) Gillissen, A., and Nowak, D. (1998) Characterization of N-acetylcysteine and ambroxol in anti-oxidant therapy. Respir. Med. 92(4), 609-623.

(82) Maret, W., and Vallee, B. L. (1998) Thiolate ligands in metallothionein confer redox activity on zinc clusters. Proc. Natl. Acad. Sci. USA. 95(7), 3478-3482.

(83) Zhang, M., Li, X., Lu, Y., Fang, X., Chen, Q., Xing, M., and He, J. (2011) Studying the genotoxic effects induced by two kinds of bentonite particles on human B lymphoblast cells in vitro. Mutat. Res.- Genet. Toxicol. Environ. Mutagen. 720(1-2), $62-66$.

(84) Donaldson, K., Poland, C. A., and Schins, R. P. F. (2010) Possible genotoxic mechanisms of nanoparticles: Criteria for improved test strategies. Nanotoxicology 4(4), 414-420.

(85) Kibanova, D., Nieto-Camacho, A., Ramirez-Apan, T., and Cervini-Silva, J. (2011) Determination of lipid peroxidation and cytotoxicity in calcium, magnesium, titanium and hectorite (SHCa-1) suspensions. Chemosphere 82(3), 418-423.

(86) Beyersmann, D., and Hartwig, A. (2008) Carcinogenic metal compounds: recent insight into molecular and cellular mechanisms. Arch. Toxicol. 82(8), 493-512.

(87) Gastaldo, J., Viau, M., Bencokova, Z., Joubert, A., Charvet, A. M., Balosso, J., and Foray, N. (2007) Lead contamination results in late and slowly repairable DNA double-strand breaks and impacts upon the ATM-dependent signaling pathways. Toxicol. Lett. 173(3), 201-214.

(88) Demidenko, Z. N., Kalurupalle, S., Hanko, C., Lim, C., Broude, E., Blagosklonny, M. V. (2008) Mechanism of G1-like arrest by low concentrations of paclitaxel: next cell cycle p53-dependent arrest with sub G1 DNA content mediated by prolonged mitosis. Oncogene 27(32), 4402-4410.

(89) Winsel, S., Sommer, A., Eschenbrenner, J., Mittelstaedt, K., Klar, U., Hammer, S., Hoffmann, J. (2011) Molecular Mode of Action and Role of TP53 in the Sensitivity to the Novel Epothilone Sagopilone (ZK-EPO) in A549 Non-Small Cell Lung Cancer Cells. Plos One 6(4). 


\section{TABLES}

Table 1: Bulk chemical composition (AAS data) of the sulfate powders used in the toxicological studies. To quantify the corundum $\left(\mathrm{Al}_{2} \mathrm{O}_{3}\right)$ abrasion from the milling process, the $\mathrm{PbSO}_{4}$ powder was also analyzed without prior milling (last column).

\begin{tabular}{lccccc}
\hline Element & Unit & $\begin{array}{c}\mathrm{CaSO}_{4} \\
\text { Average }(\mathrm{n}=3)\end{array}$ & $\begin{array}{c}\text { Zn sulfate } \\
\text { Average }(\mathrm{n}=3)\end{array}$ & $\begin{array}{c}\mathrm{PbSO}_{4} \text { Used } \\
\text { Average }(\mathrm{n}=3)\end{array}$ & $\begin{array}{c}\mathrm{PbSO}_{4} \text { Original } \\
\text { Average }(\mathrm{n}=3)\end{array}$ \\
\hline $\mathrm{Al}$ & $\mathrm{ppm}$ & $32 \pm 1$ & $<0.25$ & $15200 \pm 300$ & $<9.4$ \\
$\mathrm{Ba}$ & $\mathrm{ppm}$ & $<6.5$ & $<0.25$ & $<9.9$ & $<9.4$ \\
$\mathrm{Ca}$ & $\mathrm{ppm}$ & $286000 \pm 4000$ & $3.07 \pm 0.01$ & $490 \pm 9$ & $<22$ \\
$\mathrm{Cd}$ & $\mathrm{ppm}$ & $<0.07$ & $1.79 \pm 0.02$ & $<0.10$ & $<0.09$ \\
$\mathrm{Fe}$ & $\mathrm{ppm}$ & $<3.2$ & $0.37 \pm 0.02$ & $113 \pm 4$ & $<4.7$ \\
$\mathrm{Mg}$ & $\mathrm{ppm}$ & $124 \pm 1$ & $0.091 \pm 0.002$ & $297 \pm 1$ & $<0.8$ \\
$\mathrm{Mn}$ & $\mathrm{ppm}$ & $13.2 \pm 0.2$ & $0.20 \pm 0.02$ & $1.83 \pm 0.08$ & $<0.9$ \\
$\mathrm{Na}$ & $\mathrm{ppm}$ & $55 \pm 1$ & $1.73 \pm 0.05$ & $307 \pm 1$ & $224 \pm 2$ \\
$\mathrm{Ni}$ & $\mathrm{ppm}$ & $<3.2$ & $0.50 \pm 0.03$ & $<5.0$ & $<4.7$ \\
$\mathrm{~Pb}$ & $\mathrm{ppm}$ & $<3.2$ & $8.5 \pm 0.4$ & $638000 \pm 3000$ & $680000 \pm 3000$ \\
$\mathrm{Zn}$ & $\mathrm{ppm}$ & $55 \pm 3$ & $285000 \pm 1000$ & $<19.8$ & $<18.7$ \\
\hline & & & & &
\end{tabular}

Table 2: Concentrations (AAS data) of $\mathrm{Ca}, \mathrm{Zn}, \mathrm{Pb}$ and $\mathrm{Fe}$ in RPMI, RPMI $+5 \% \mathrm{FBS}$, and in the supernatants of the metal sulfates and $\mathrm{ZnCl}_{2}$ dispersed in these media. These data were used to calculate the solubility of the metal sulfates in culture medium at bioassay conditions $\left(37^{\circ} \mathrm{C}, \mathrm{pH}=7.4\right)$.

\begin{tabular}{|c|c|c|c|c|c|c|c|}
\hline & $\begin{array}{l}\text { Concentration } \\
\text { in 6-well }\end{array}$ & Concentration & $\begin{array}{l}\text { Culture } \\
\text { medium }\end{array}$ & $\begin{array}{c}\text { Ca } \\
\text { ppm }\end{array}$ & $\begin{array}{l}\text { Zn } \\
\text { ppm }\end{array}$ & $\begin{array}{l}\mathbf{P b} \\
\mathrm{ppm}\end{array}$ & $\begin{array}{c}\text { Fe } \\
\text { ppm }\end{array}$ \\
\hline RPMI & & & & 19.8 & 0.08 & $<0.005^{2)}$ & $<0.005^{2)}$ \\
\hline RPMI+5\%FBS & & & & 54.4 & 0.13 & $<0.005^{2)}$ & $0.12^{2)}$ \\
\hline \multirow[t]{3}{*}{$\mathrm{CaSO}_{4}$} & $50 \mu \mathrm{g} / \mathrm{cm}^{2}$ & $80 \mathrm{mg} / \mathrm{L}$ & RPMI & 41.7 & & & \\
\hline & $100 \mu \mathrm{g} / \mathrm{cm}^{2}$ & $160 \mathrm{mg} / \mathrm{L}$ & RPMI & 50.5 & & & \\
\hline & $100 \mu \mathrm{g} / \mathrm{cm}^{2}$ & $160 \mathrm{mg} / \mathrm{L}$ & RPMI+5\%FBS & 89.3 & & & \\
\hline \multirow[t]{3}{*}{ Zn sulfate } & $10 \mu \mathrm{g} / \mathrm{cm}^{2}$ & $16 \mathrm{mg} / \mathrm{L}$ & RPMI & & $2.45 \pm 0.03^{1)}$ & & \\
\hline & $25 \mu \mathrm{g} / \mathrm{cm}^{2}$ & $40 \mathrm{mg} / \mathrm{L}$ & RPMI & & $2.75 \pm 0.04^{1)}$ & & \\
\hline & $100 \mu \mathrm{g} / \mathrm{cm}^{2}$ & $160 \mathrm{mg} / \mathrm{L}$ & RPMI+5\%FBS & & $42.4^{2)}$ & & \\
\hline $\mathrm{PbSO}_{4}$ & $100 \mu \mathrm{g} / \mathrm{cm}^{2}$ & $160 \mathrm{mg} / \mathrm{L}$ & RPMI+5\%FBS & & & $1.67^{2)}$ & \\
\hline \multirow[t]{3}{*}{$\overline{\mathrm{ZnCl}}{ }_{2}$} & $4.2 \mu \mathrm{g} / \mathrm{cm}^{2}$ & $6.75 \mathrm{mg} / \mathrm{L}$ & RPMI & & $2.26+0.07^{1)}$ & & \\
\hline & $8.4 \mu \mathrm{g} / \mathrm{cm}^{2}$ & $13.5 \mathrm{mg} / \mathrm{L}$ & RPMI & & $2.5+0.1^{1)}$ & & \\
\hline & $100 \mu \mathrm{g} / \mathrm{cm}^{2}$ & $160 \mathrm{mg} / \mathrm{L}$ & RPMI+5\%FBS & & $85.1^{2)}$ & & \\
\hline
\end{tabular}




\section{FIGURES}
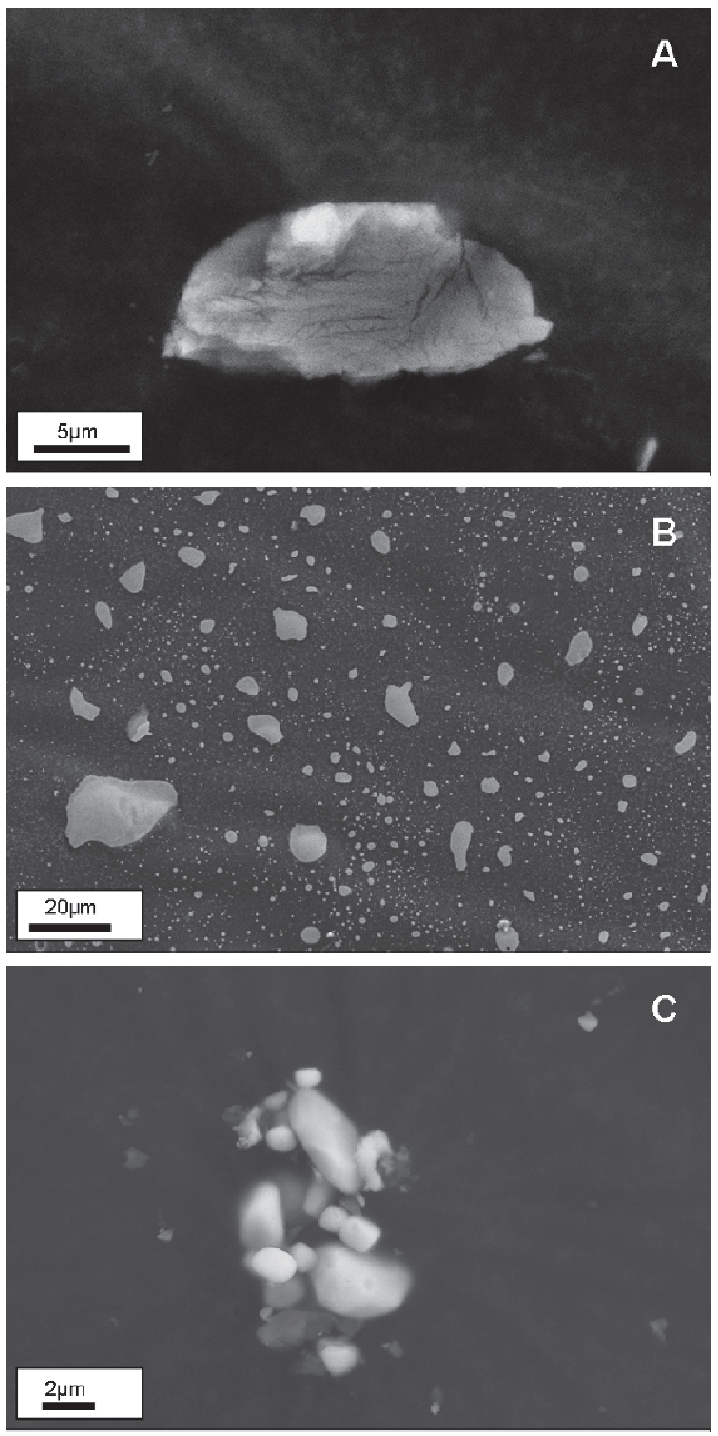

Figure 1. Secondary electron images of the sulfate powders after heat treatment. (A) Anhydrite, $\mathrm{CaSO}_{4}$; (B) Gunningite, $\mathrm{ZnSO}_{4} \cdot \mathrm{H}_{2} \mathrm{O}$; and (C) Anglesite, $\mathrm{PbSO}_{4}$. 

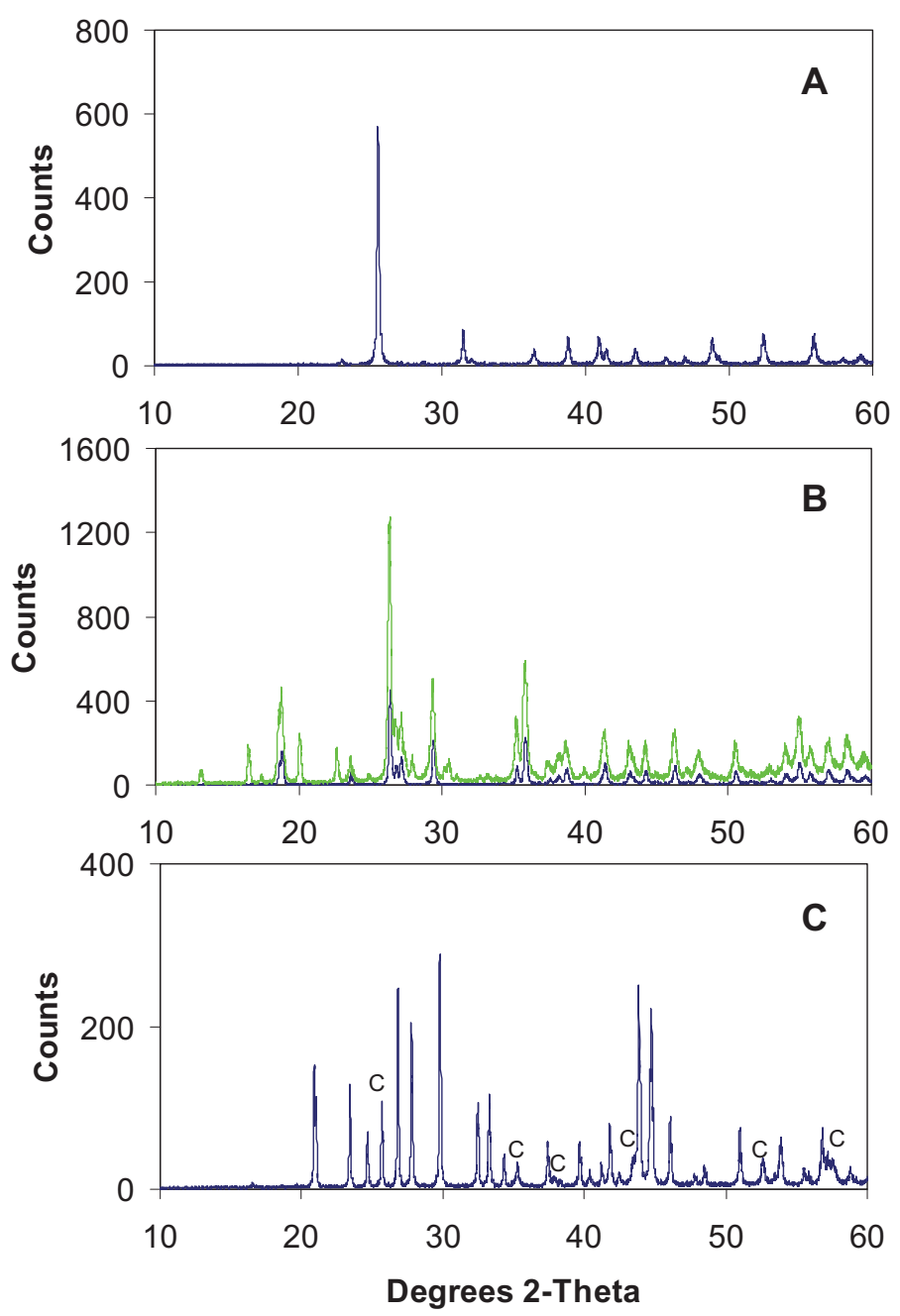

Figure 2. XRD patterns of the sulfate powders after heat treatment $\left(180^{\circ} \mathrm{C}\right.$ for 4 hours) showing the reflections between 10 and $60{ }^{\circ} 2 \theta$. (A) Calcium sulfate is consistent with the anhydrite $\left(\mathrm{CaSO}_{4}\right)$ spectrum; (B) $\mathrm{Zn}$ sulfate is gunningite $\left(\mathrm{ZnSO}_{4} \cdot \mathrm{H}_{2} \mathrm{O}\right.$, blue line); and $(\mathrm{C}) \mathrm{Pb}$ sulfate is anglesite $\left(\mathrm{PbSO}_{4}\right)$, whereby peaks of corundum (labeled with $\mathrm{C}$ ) are due to contamination. The second $\mathrm{Zn}$-sulfate pattern, shown as green line in (B), represents the $\mathrm{Zn}$ sulfate sample after 12-month storage and, according to our Rietveld refinement, is a mixture of $79 \mathrm{wt} \%$ gunningite and $21 \mathrm{wt} \%$ boyleite $\left(\mathrm{ZnSO}_{4} \cdot 4 \mathrm{H}_{2} \mathrm{O}\right)$. 

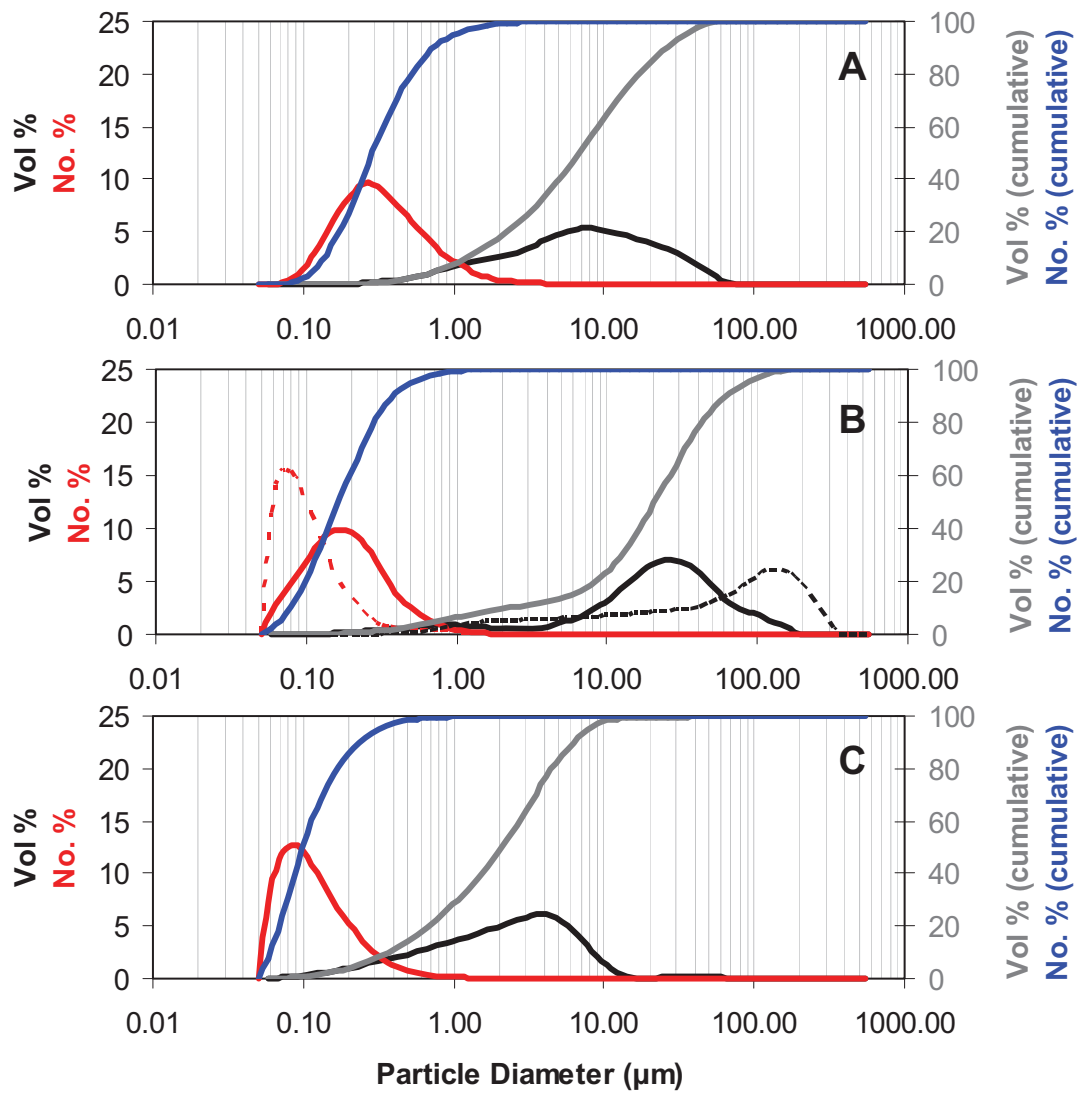

Figure 3. Particle-size distributions of (A) $\mathrm{CaSO}_{4}$, (B) $\mathrm{ZnSO}_{4} \cdot \mathrm{H}_{2} \mathrm{O}$, and (C) $\mathrm{PbSO}_{4}$, as determined by laser diffraction. Black lines: volume percentage of particles with a specific diameter; grey lines: cumulative volume percentage; red lines: number percentage; blue lines: cumulative number percentage. The dotted red line in (B) shows the number percentage, dotted black line the volume percentage of $\mathrm{Zn}$ sulfate after 12-month storage. 


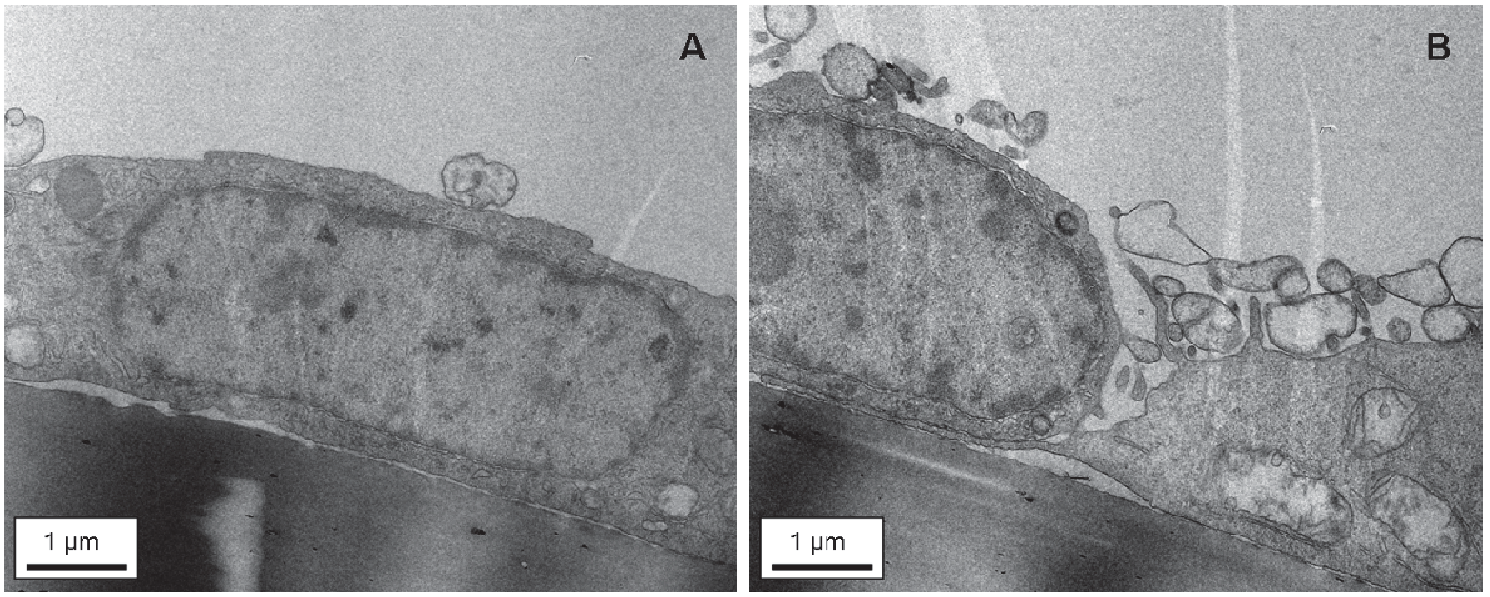

Figure 4. TEM images showing representative A549 cells, which were not exposed to any particles. Most cells ( $>80 \%$ ) show only sporadic vesicles (A), and only a few cells showed more abundant vesicles (B). 

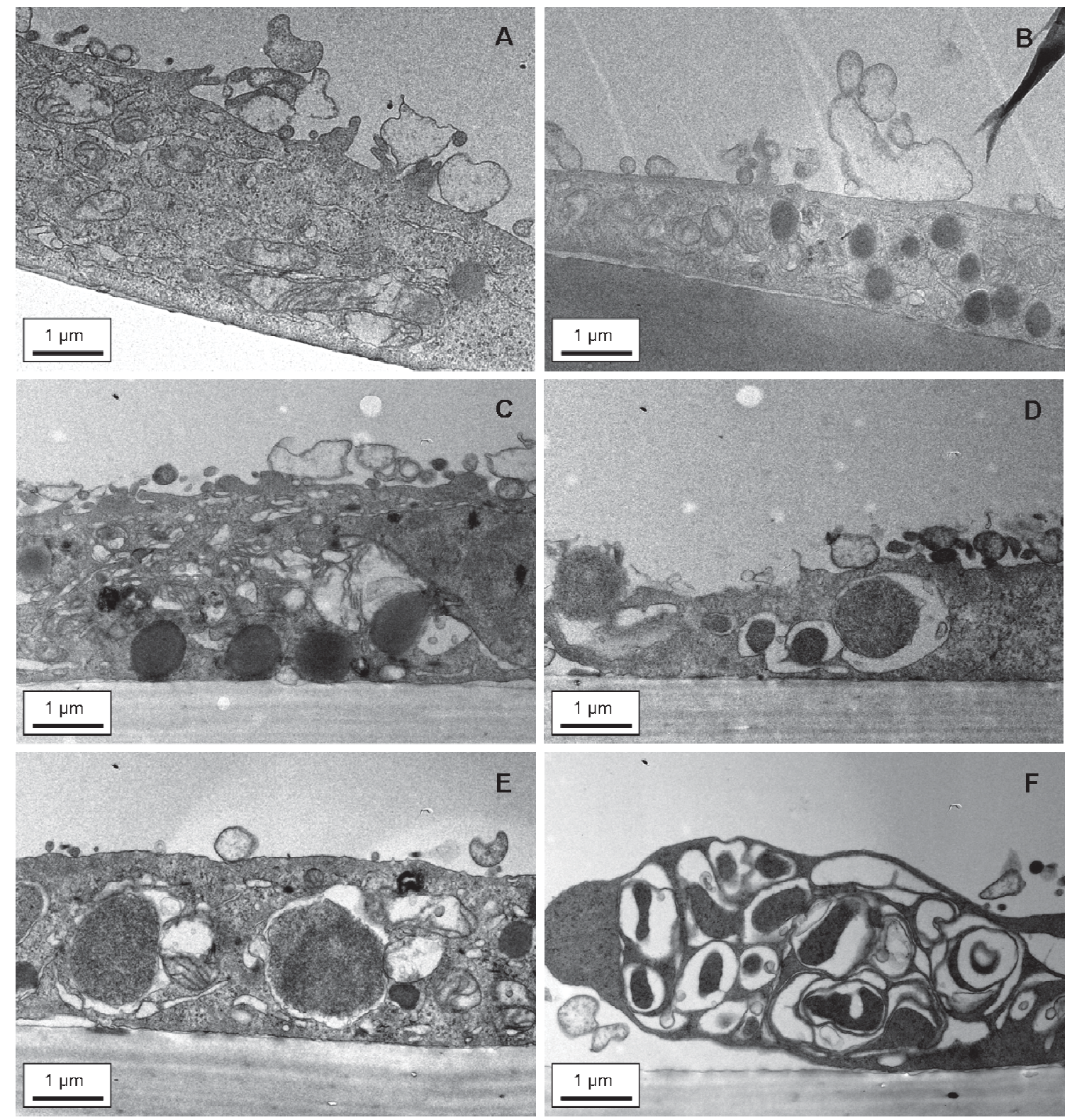

Figure 5. TEM images showing examples of A549 cells exposed to (A-B) $1 \mu \mathrm{g} / \mathrm{cm}^{2}$, and (CF) $10 \mu \mathrm{g} / \mathrm{cm}^{2}$ of $\mathrm{Zn}$ sulfate for $24 \mathrm{~h}$. (A) After exposure to $1 \mu \mathrm{g} / \mathrm{cm}^{2} \mathrm{Zn}$ sulfate, cells show several vesicles on the cell surface and some vesicles in the interior. (B,C) Dark round vesicles are a characteristic feature observed in cells exposed to $\mathrm{Zn}$ sulfate. (D-F) After exposure to $10 \mu \mathrm{g} / \mathrm{cm}^{2} \mathrm{Zn}$ sulfate, the dark vesicles, presumably zincosomes, are larger and more abundant than in cells exposed to $1 \mu \mathrm{g} / \mathrm{cm}^{2}$, and the dark vesicles are commonly surrounded by another, larger vesicle (bright in image). 

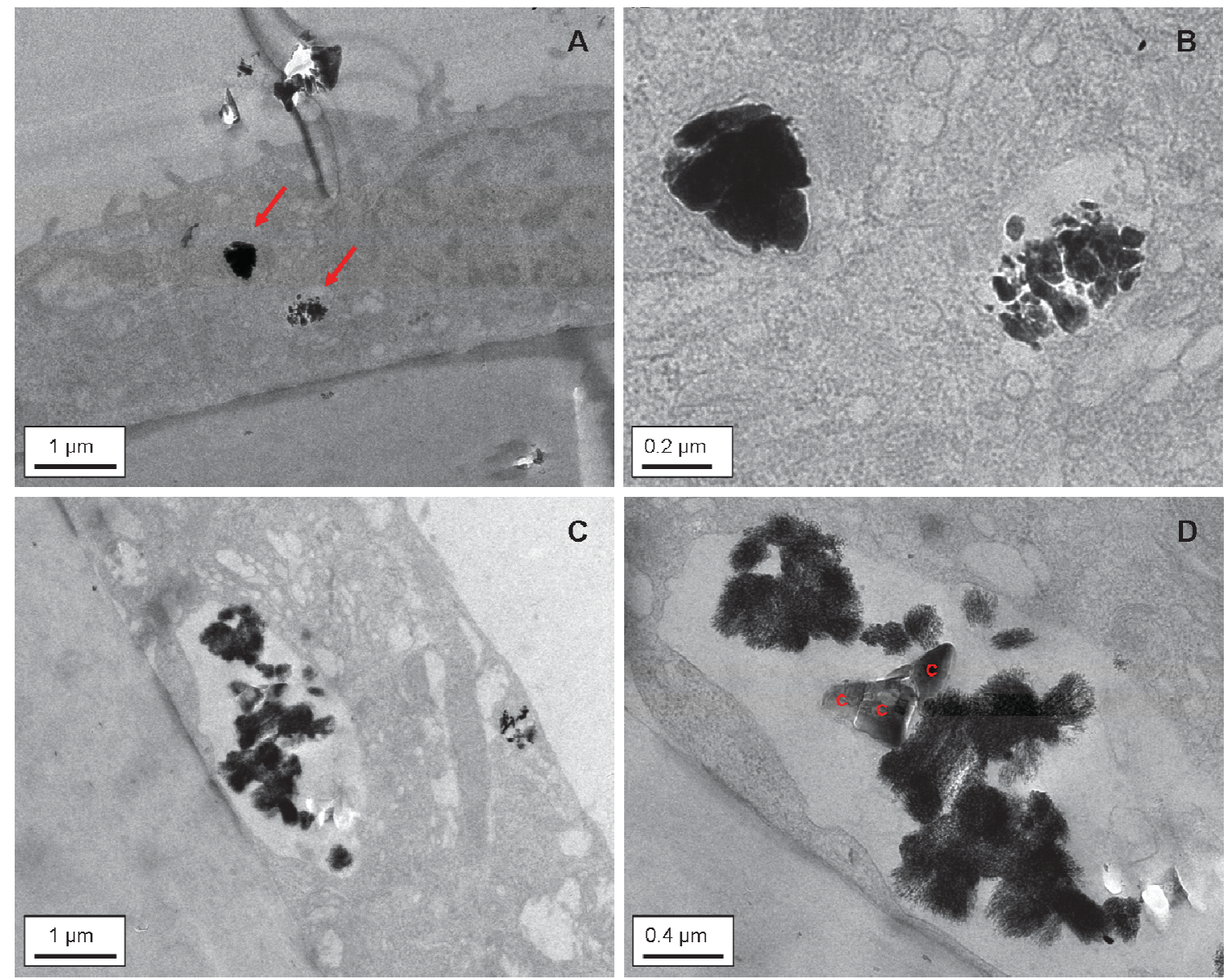

Figure 6. TEM images of A549 cells exposed to $100 \mu \mathrm{g} / \mathrm{cm}^{2} \mathrm{PbSO}_{4}$ for (A, B) $4 \mathrm{~h}$ and (C, D) 24 h. (A) $\mathrm{PbSO}_{4}$ particle in the cytoplasm and $\mathrm{PbSO}_{4}$ agglomerate in a vesicle. (B) Detail of (A). (C) needle-like to feathery black spots are $\mathrm{PbSO}_{4}$ particles with small $\mathrm{Ca}-\mathrm{K} \alpha$ peaks. (D) Detail of $(\mathrm{C})$. Crystals (labeled with $\mathrm{C}$ ) with sharp edges are $\mathrm{Al}_{2} \mathrm{O}_{3}$ particles (contaminants from milling). 


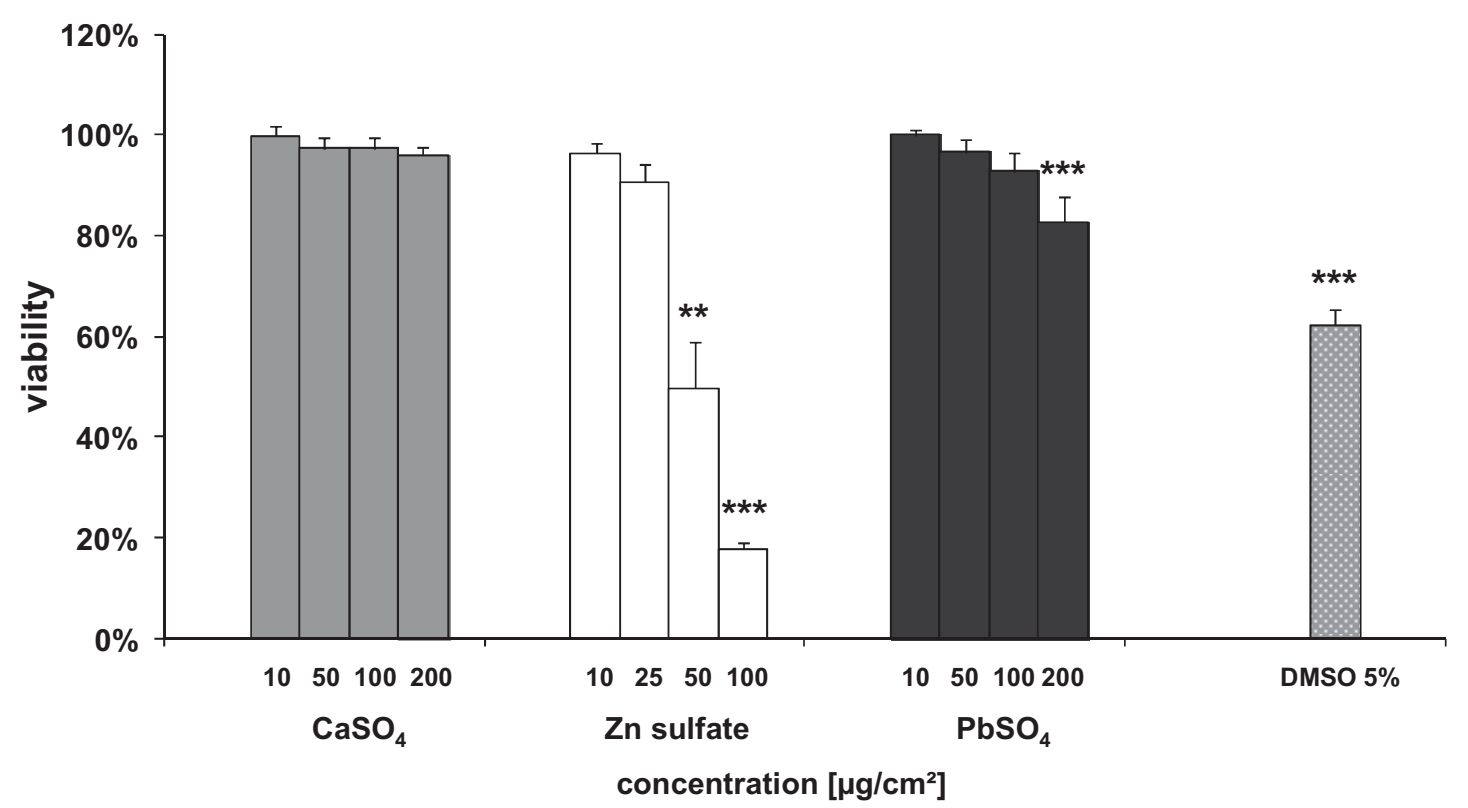

Figure 7. Cell viability as percent viable cells compared to untreated control in human lung cells (A549), monitored by the WST-1 assay following 24-h exposure. Positive control: DMSO (5\%). Each bar represents the mean $\pm \mathrm{SE}$ of at least three independent experiments; ${ }^{*} \mathrm{p}<0.05 ; * * \mathrm{p}<0.01 ; * * * \mathrm{p}<0.001$ versus untreated control (One-way ANOVA followed by Dunnett's post-hoc). 


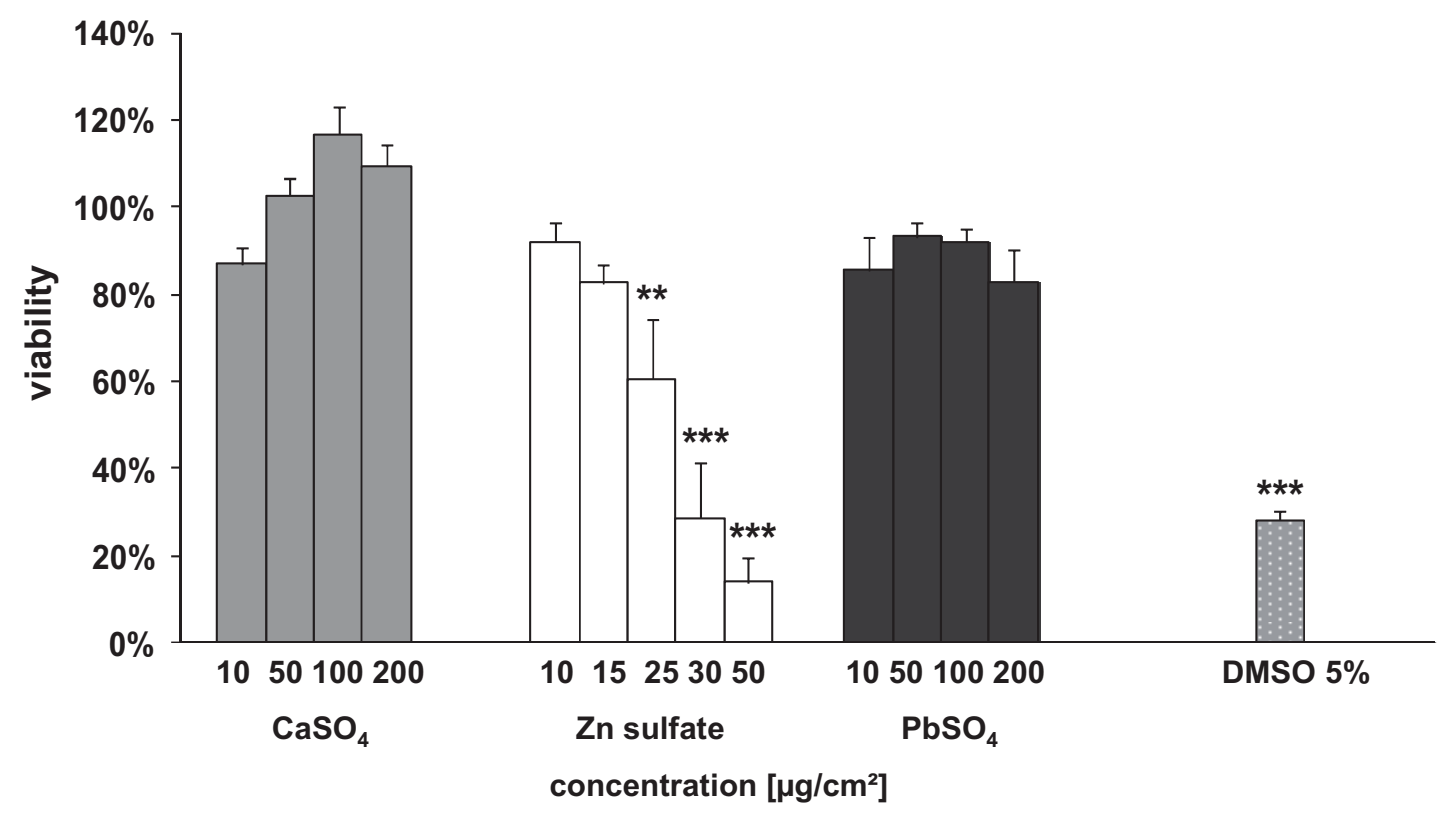

Figure 8. Cell viability as percent viable cells compared to untreated control in human lung cells (A549), monitored by the NR-uptake assay following 24-h exposure. Positive control: DMSO (5\%). Each bar represents the mean \pm SE of at least three independent experiments; ${ }^{*} \mathrm{p}<0.05 ;{ }^{* *} \mathrm{p}<0.01 ;{ }^{* * *} \mathrm{p}<0.001$ versus untreated control (One-way ANOVA followed by Dunnett's post-hoc). 


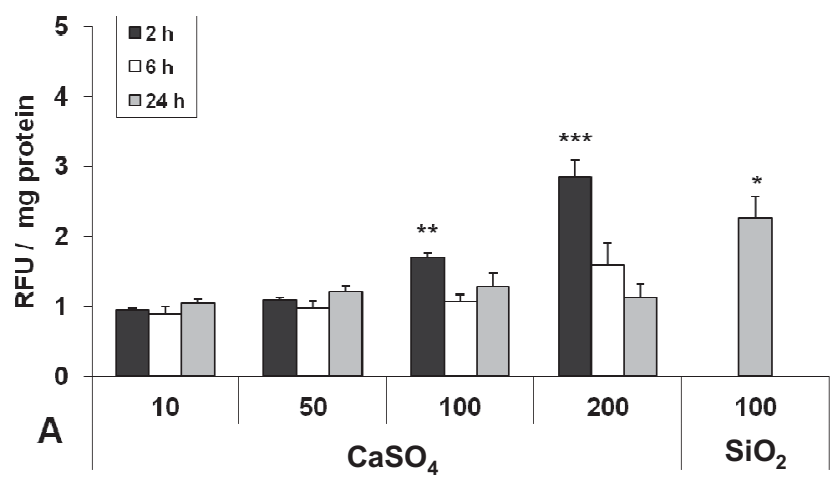

concentration $\left[\mu \mathrm{g} / \mathrm{cm}^{2}\right]$

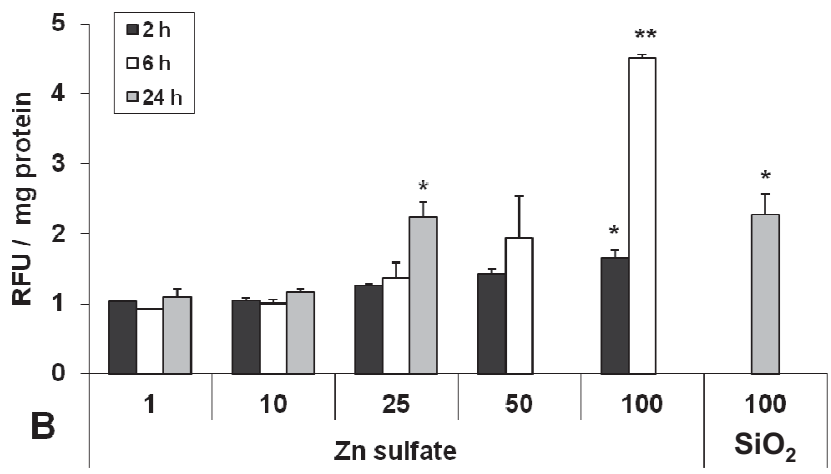

concentration $\left[\mu \mathrm{g} / \mathrm{cm}^{2}\right]$

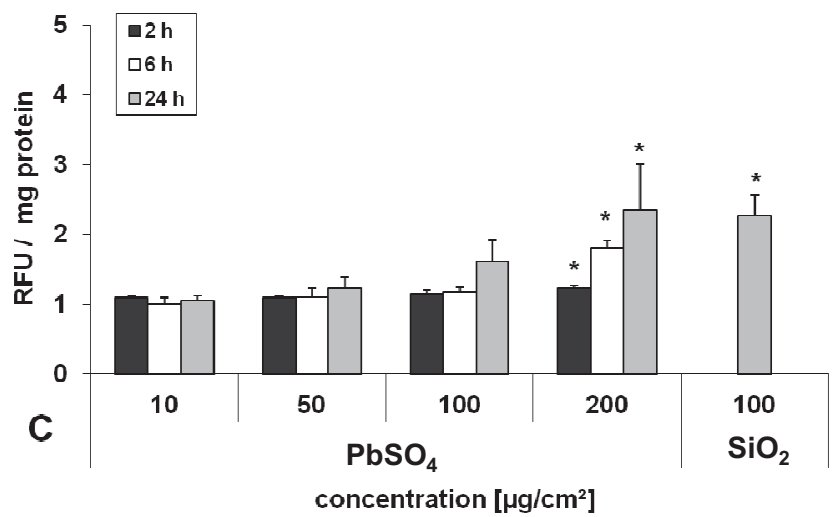

Figure 9. ROS formation in human lung cells (A549), as measured by the DCFH-DA assay after exposure to (A) $\mathrm{CaSO}_{4}$, (B) $\mathrm{Zn}$ sulfate, and (C) $\mathrm{PbSO}_{4}$. Results are expressed as relative fluorescent units (RFU) per mg protein compared to untreated cells, which were loaded with DCFH-DA without exposure to particles. As positive control, cells were exposed to $\mathrm{SiO}_{2}$ (quartz Min-U-Sil 5, $100 \mu \mathrm{g} / \mathrm{cm}^{2}$ ) for $24 \mathrm{~h}$. Data represent mean \pm SE from at least three independent experiments; ${ }^{*} \mathrm{p}<0.05 ;{ }^{* *} \mathrm{p}<0.01 ;{ }^{* * *} \mathrm{p}<0.001$ versus untreated control (One-way ANOVA followed by Dunnett's post-hoc). 


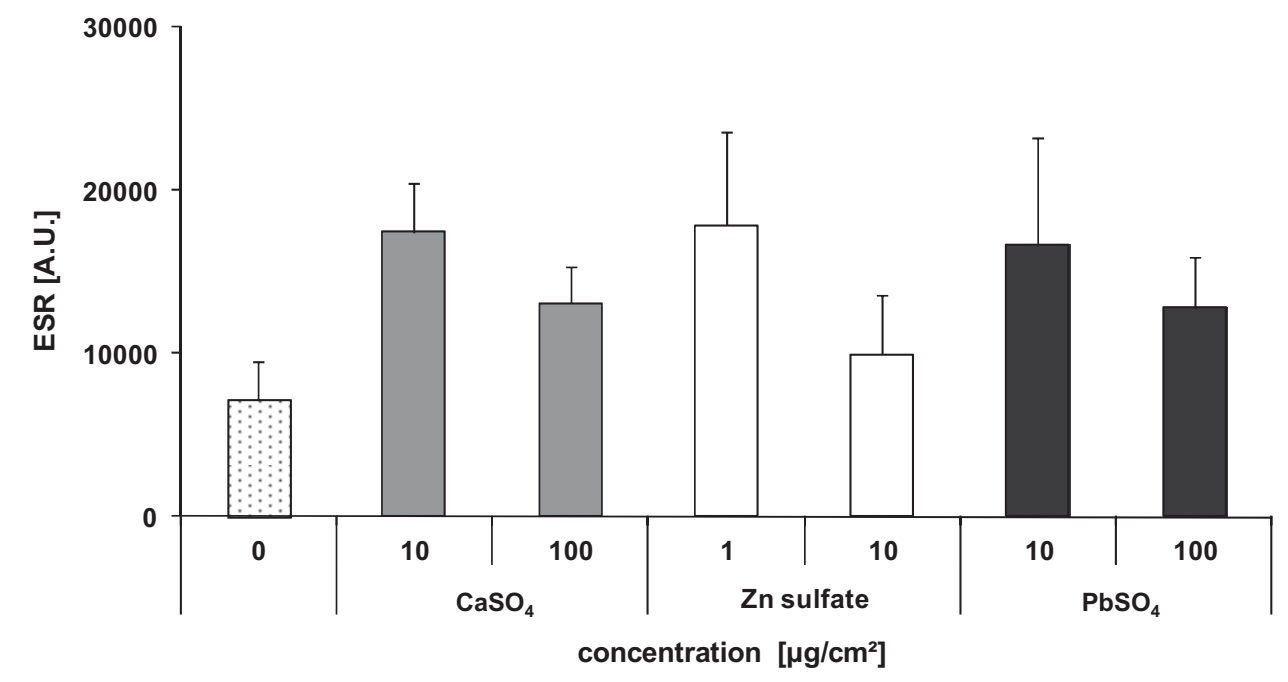

Figure 10. ROS formation in human lung cells (A549), as measured by EPR spectroscopy after $24 \mathrm{~h}$ exposure to different metal sulfates. Results are expressed as arbitrary units (A.U.). For complete oxidation of $\mathrm{CMH}$, a mean value of $5.57 \times 10^{6}$ A.U. was obtained by adding $\mathrm{KO}_{2}$. Data represent mean $\pm \mathrm{SE}$ from four independent experiments.

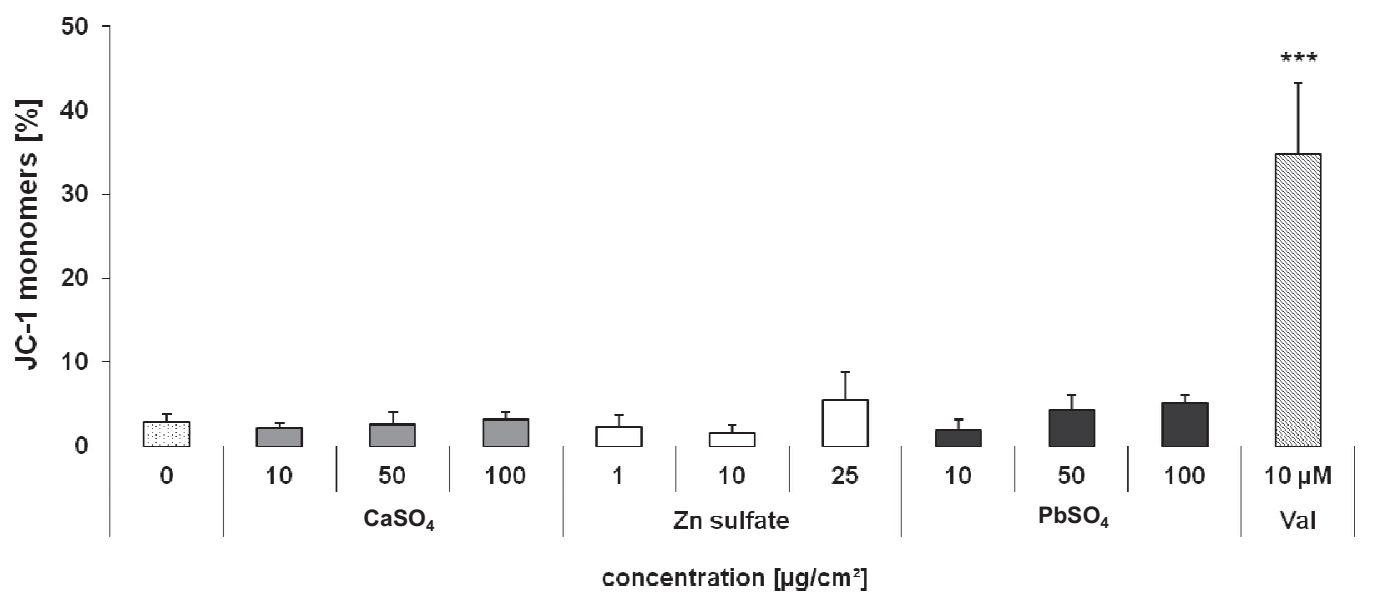

Figure 11. Changes in mitochondrial membrane potential (MMP) induced by metal sulfates in human lung cells (A549) upon 24-h treatment. Cells were stained with $2 \mu \mathrm{g} / \mathrm{L}$ JC-1 for 0.5 h. Appropriate gates were made to define JC-1 aggregates and JC-1 monomers. MMP is expressed as the percentage of JC-1 monomers. Positive control: valinomycin (Val, $10 \mu \mathrm{M})$. 
Data represent mean \pm SD from at least three independent experiments; $* * * p<0.001$ versus untreated control (One-way ANOVA followed by Dunnett's post-hoc). 


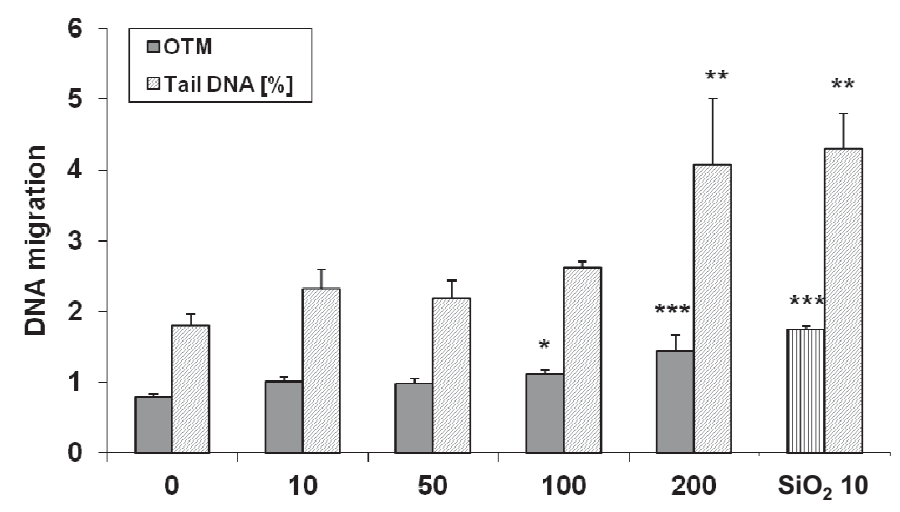

A

concentration $\left[\mu \mathrm{g} / \mathrm{cm}^{2}\right]$

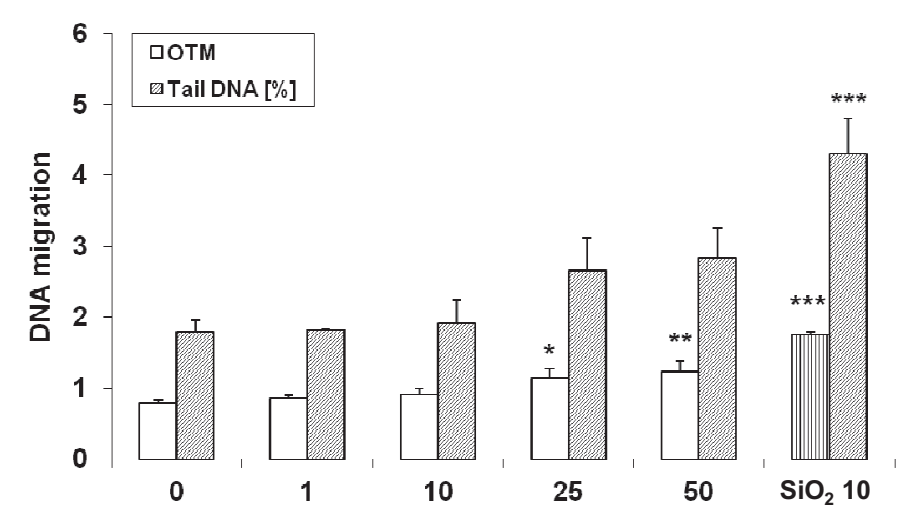

B

concentration $\left[\mu \mathrm{g} / \mathrm{cm}^{2}\right]$

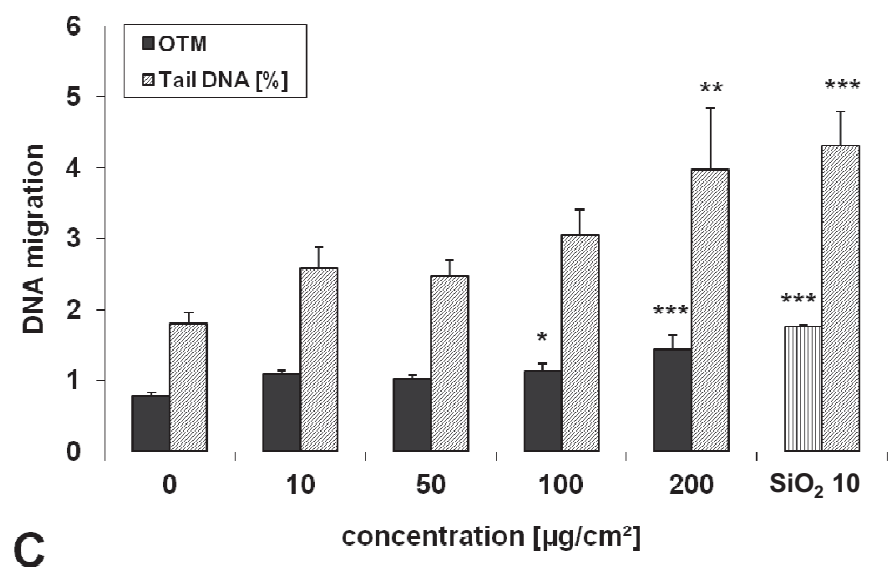

Figure 12. DNA migration assessed by the Comet assay using the parameters OTM and \%Tail DNA, in human lung cells (A549) after 4-h exposure to suspensions containing (A) $\mathrm{CaSO}_{4}$, (B) Zn sulfate, and (C) $\mathrm{PbSO}_{4}$. Positive control: $\mathrm{SiO}_{2}$ (quartz Min-U-Sil 5, $\left.10 \mu \mathrm{g} / \mathrm{cm}^{2}\right)$. Data are mean $\pm \mathrm{SE}$ of three independent experiments. ${ }^{*} \mathrm{p}<0.05 ;{ }^{* *} \mathrm{p}<0.01$; $* * * \mathrm{p}<0.001$ versus untreated control (One-way ANOVA followed by Dunnett's post-hoc). 

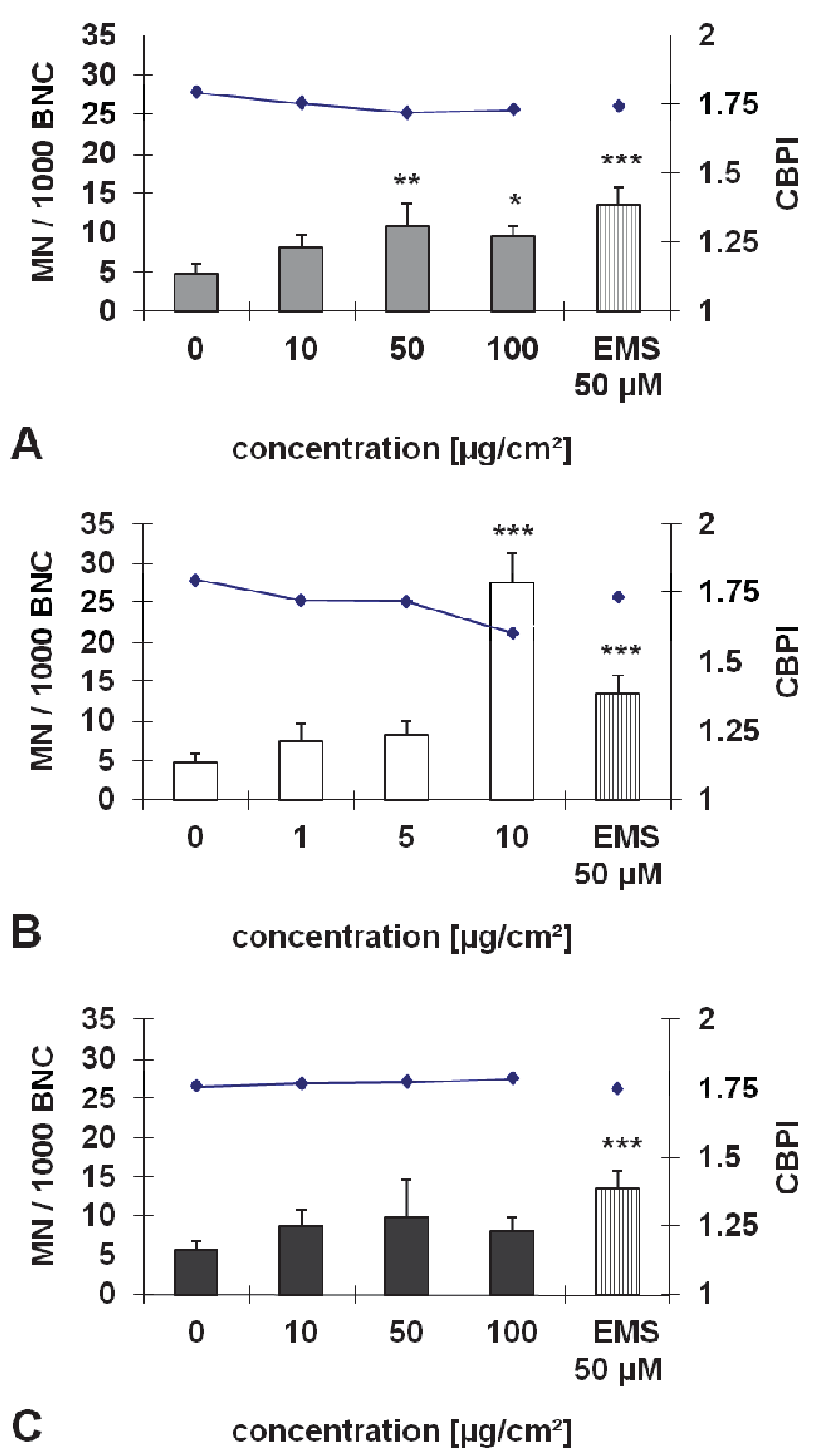

Figure 13. Cytokinesis block proliferation index (CBPI) (diamonds) and micronuclei induction (bars) in human lung cells (A549) upon 24-h treatment with suspensions containing (A) $\mathrm{CaSO}_{4}$, (B) $\mathrm{Zn}$ sulfate, and (C) $\mathrm{PbSO}_{4}$. Positive control: EMS (50 $\left.\mu \mathrm{M}\right)$. Data represent mean \pm SD from at least three independent experiments; ${ }^{*} \mathrm{p}<0.05 ; * * p<0.01 ; * * * p<0.001$ versus untreated control (One-way ANOVA followed by Dunnett's post-hoc). MN: micronuclei; BNC: binucleated cells. 

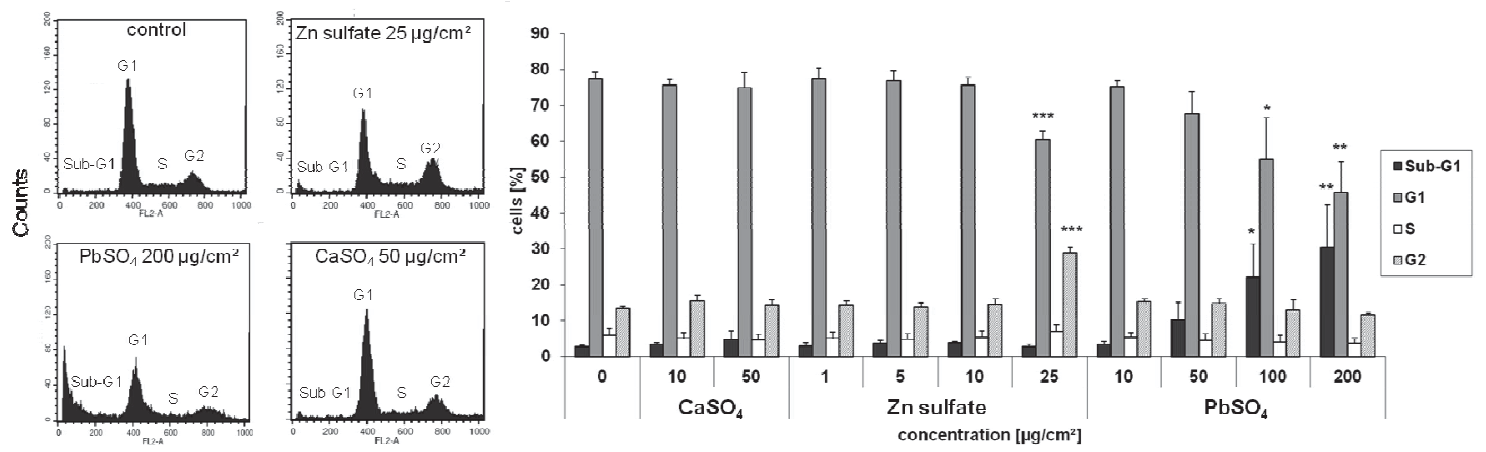

Figure 14. DNA content indicating changes in cell-cycle progression induced by metal sulfates in human lung cells (A549) upon 24-h treatment. Cells were stained with $40 \mathrm{mg} / \mathrm{L} \mathrm{PI}$ for 30 min and analyzed by flow cytometry. Zinc sulfate caused increased G2 peak, whereas $\mathrm{PbSO}_{4}$ exerts a dramatically increased Sub-G1 population. On the left-hand side, representative histograms are shown. Data represent mean $\pm \mathrm{SD}$ of relative cell-cycle distribution from three independent experiments. ${ }^{*} \mathrm{p}<0.05,{ }^{* *} \mathrm{p}<0.01,{ }^{* * *} \mathrm{p}<0.001$ versus untreated control (One-way ANOVA followed by Dunnett's post-hoc). 
A

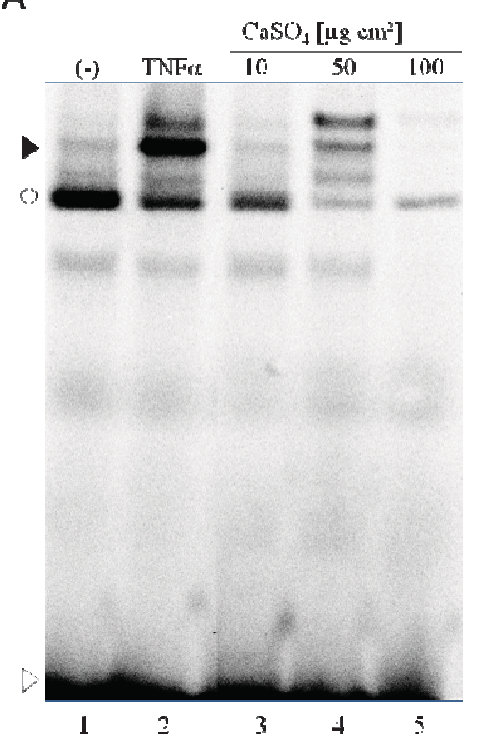

B

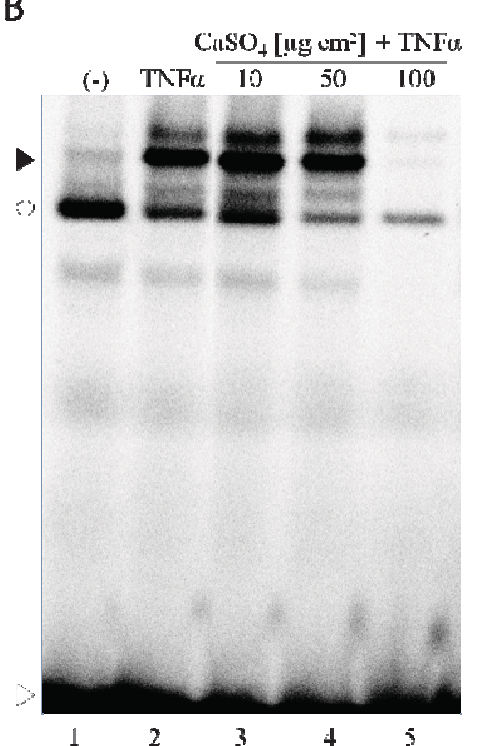

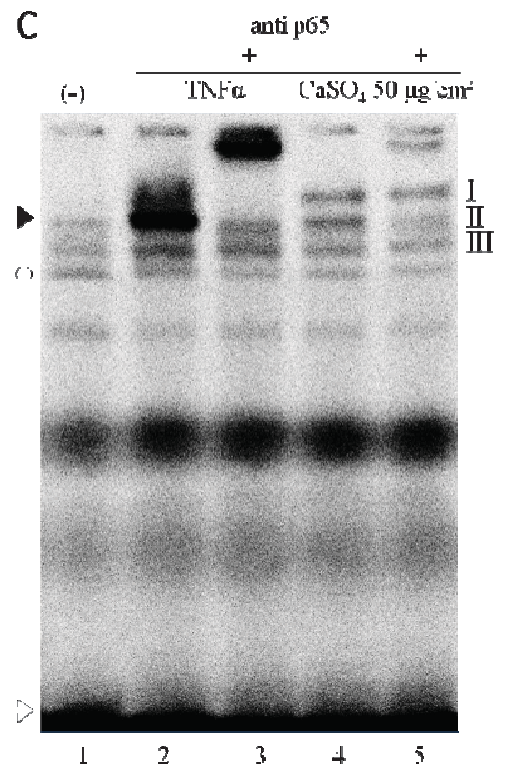

Figure 15. (A) Effect on NF-kB DNA binding after exposure of A549 to $\mathrm{CaSO}_{4}$. Lane 1 (-) shows unstimulated control cells, lane 2 cells stimulated with $\mathrm{TNF} \alpha(4 \mathrm{ng} / \mathrm{mL}, 30 \mathrm{~min})$ as a positive control; in lanes 3 to 5 cells were treated with 10,50 or $100 \mu \mathrm{g} / \mathrm{cm}^{2} \mathrm{CaSO}_{4}$ for $6 \mathrm{~h}$. (B) Effect on $\mathrm{TNF} \alpha$-induced $\mathrm{NF}-\kappa \mathrm{B}$ activation after pretreatment with $\mathrm{CaSO}_{4}$. Lane 1 shows unstimulated control cells, lane 2 cells stimulated with $\mathrm{TNF} \alpha(4 \mathrm{ng} / \mathrm{mL}, 30 \mathrm{~min})$ as a positive control; in lanes 3 to 5 cells were pretreated with 10,50 or $100 \mu \mathrm{g} / \mathrm{cm}^{2} \mathrm{CaSO}_{4}$ for $5.5 \mathrm{~h}$ and subsequently stimulated with TNF $\alpha$ (4 ng/mL) for $30 \mathrm{~min}$. (C) Supershift analysis of activated NF- $\kappa$ B. Lane 1 shows unstimulated control cells; in lanes 2 and 3 cells were treated with $\mathrm{TNF} \alpha(4 \mathrm{ng} / \mathrm{mL})$ for $30 \mathrm{~min}$; lanes 4 and 5 show cells treated with $50 \mu \mathrm{g} / \mathrm{cm}^{2} \mathrm{CaSO}_{4}$ for $6 \mathrm{~h}$; samples in lanes 3 and 5 were additionally incubated with an anti p65 antibody for 45 minutes before mixing with the probe. Equal amounts of protein from nuclear cell extracts were analyzed for NF- $\mathrm{B}$ activity by EMSA. A filled arrowhead indicates the position of the NF$\kappa \mathrm{B}$ DNA complexes. The open circle denotes a nonspecific activity binding to the probe, and the open arrowhead shows unbound oligonucleotide. One representative EMSA is shown. 


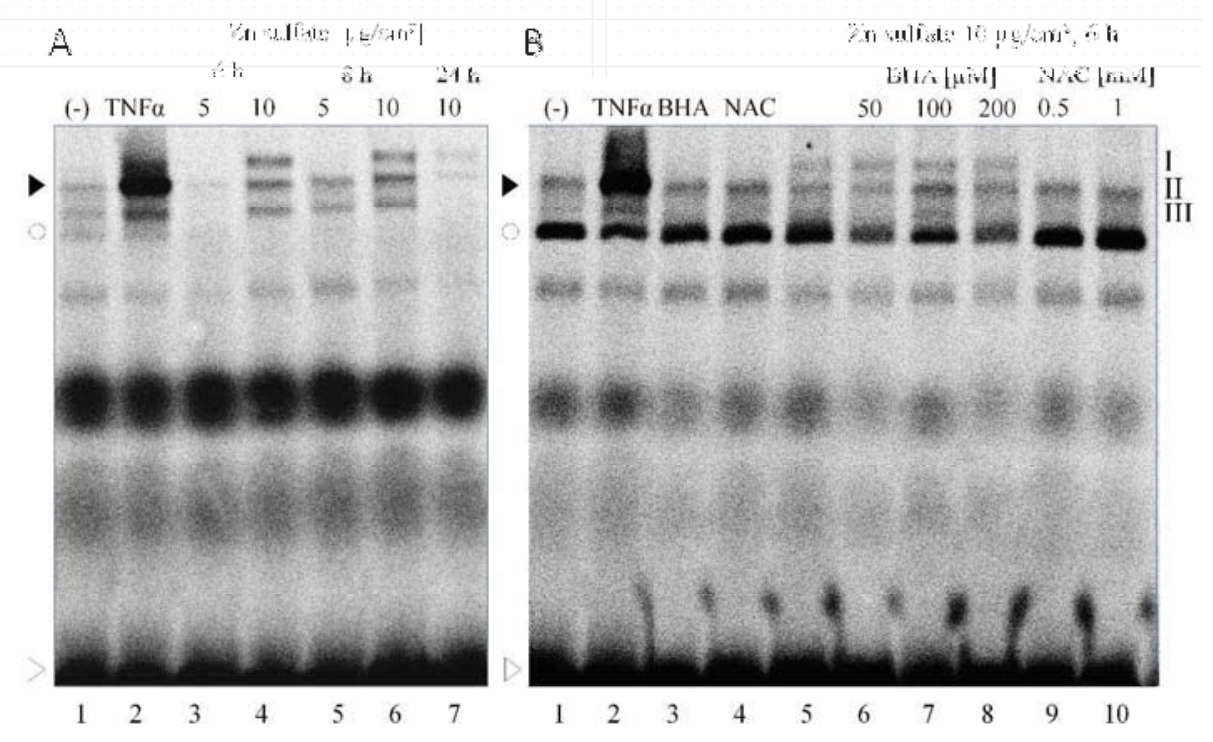

Figure 16. (A) Effect on NF-kB DNA binding after exposure of A549 to Zn sulfate. Lane 1 ( - ) shows non-stimulated control cells, lane 2 cells stimulated with TNF $\alpha$ (4 ng/mL, $30 \mathrm{~min})$ as a positive control; in lanes 3 to 7 cells were treated with 5 or $10 \mu \mathrm{g} / \mathrm{cm}^{2} \mathrm{Zn}$ sulfate for the indicated time durations. (B) Effect of BHA and NAC pretreatment on particle-induced NF$\kappa \mathrm{B}$ activation. Lane 1 shows unstimulated control cells, lane 2 cells stimulated with TNF $\alpha$ $(4 \mathrm{ng} / \mathrm{mL}, 30 \mathrm{~min})$ as a positive control; in lanes 3 and 4 cells were incubated with either $200 \mu \mathrm{M}$ BHA or $1 \mathrm{mM} \mathrm{NAC}$ for $7 \mathrm{~h}$; in lanes 5 to 10 cells were treated with $10 \mu \mathrm{g} / \mathrm{cm}^{2} \mathrm{Zn}$ sulfate for $6 \mathrm{~h}$; on lane $6-10 \mathrm{BHA}$ and NAC at different concentrations $(50-200 \mu \mathrm{M}$ and $0.5-1 \mathrm{mM}$ respectively) were added 60 min prior to particle stimulation. Equal amounts of protein from nuclear cell extracts were analyzed for NF-кB activity by EMSA. A filled arrowhead indicates the position of the NF- $\mathrm{kB}$ DNA complexes. The open circle denotes a nonspecific activity binding to the probe, and the open arrowhead shows unbound oligonucleotide. One representative EMSA is shown. 

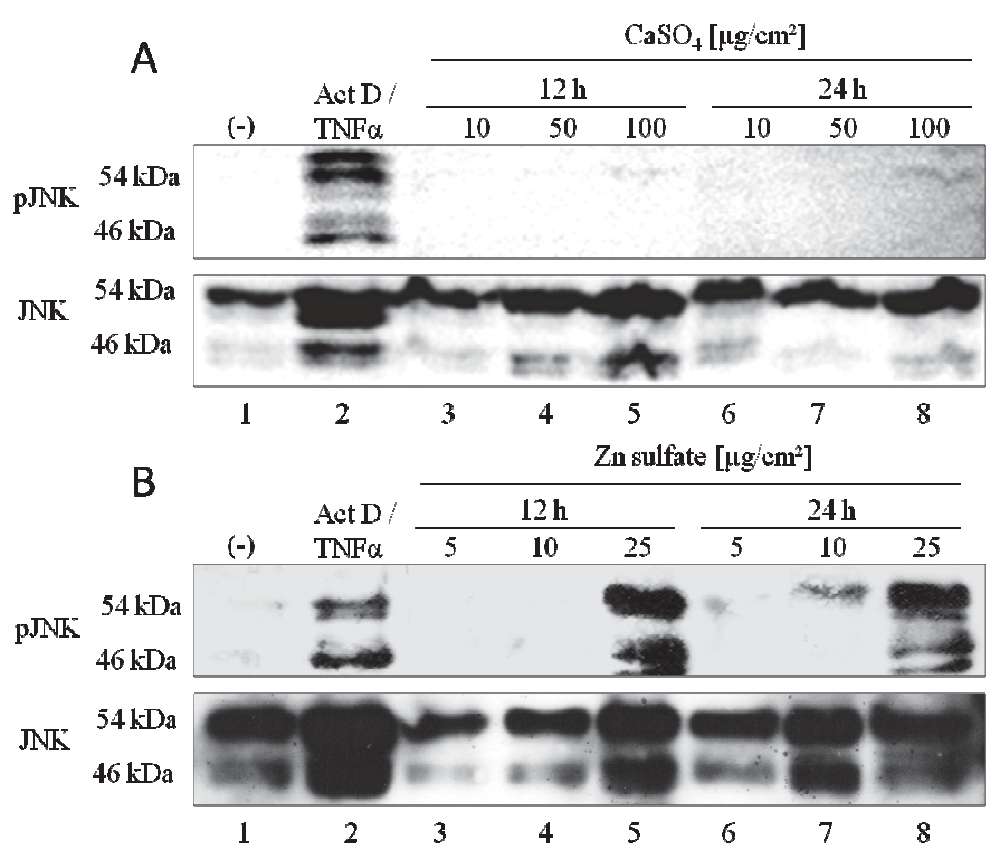

Figure 17. Activation of $\mathrm{JNK}$ by $\mathrm{CaSO}_{4}$ and $\mathrm{Zn}$ sulfate measured by Western blot analysis. (A) Analysis of phospho-JNK (pJNK) after treatment with $\mathrm{CaSO}_{4}\left(10-100 \mu \mathrm{g} / \mathrm{cm}^{2}\right)$ for the indicated times (lanes $3-8$ ); lane 1 (-) shows untreated cells, in lane 2 cells were treated with a combination of actinomycin $\mathrm{D}(\mathrm{ActD}, 333 \mathrm{nM})$ and $\mathrm{TNF} \alpha(4 \mathrm{ng} / \mathrm{mL})$ as the positive control. (B) Western blot analysis after treatment with $\mathrm{Zn}$ sulfate $\left(5-25 \mu \mathrm{g} / \mathrm{cm}^{2}\right)$ for the indicated times (lanes $3-8$ ); lane 1 shows untreated cells, in lane 2 cells were treated with a combination of actinomycin D (ActD, $333 \mathrm{nM})$ and $\mathrm{TNF} \alpha(4 \mathrm{ng} / \mathrm{mL})$. One representative Western blot is shown. 


\title{
Cellular uptake and toxic effects of fine and ultrafine metal-sulfate particles in human A549 lung epithelial cells
}

\author{
Mathias Könczöl, ${ }^{\dagger,+}$ Ella Goldenberg, ${ }^{\S}$ Sandra Ebeling, ${ }^{\not+}$ Bianca Schäfer, ${ }^{+}$Manuel Garcia- \\ Käufer, ${ }^{\dagger}$ Richard Gminski, ${ }^{\dagger}$ Bernard Grobéty, $"$ Barbara Rothen-Rutishauser, ${ }^{\perp}$ Irmgard \\ Merfort, ${ }^{*}$ Reto Gieré, ${ }^{*} \S$ and Volker Mersch-Sundermann $*{ }^{\dagger}$ \\ * shared senior authorship \\ $\uparrow^{\dagger}$ Department of Environmental Health Sciences, University Medical Center Freiburg, \\ Freiburg, Germany \\ * Department of Pharmaceutical Biology and Biotechnology, University of Freiburg, Freiburg, \\ Germany \\ $\S$ Institute of Geosciences, University of Freiburg, Freiburg, Germany \\ ॥ Department of Geosciences and FRIMAT, University of Fribourg, Fribourg, Switzerland \\ ${ }^{\perp}$ Adolphe Merkle Institute, University of Fribourg, Fribourg, Switzerland
}

SUPPORTING INFORMATION 


\section{MATERIALS AND METHODS}

\section{Rietveld refinement}

The structural parameters for the minerals were taken from the structure database operated by the Mineralogical Society of America (http://www.minsocam.org/MSA/ Crystal Database.html). The original data for gunningite are from Wildner and Giester, ${ }^{1}$ the data for boyleite from Blake et al. ${ }^{2}$ The lattice parameters, the crystallite size and the isotropic temperature factors for $\mathrm{Zn}$ were refined. The positional parameters were kept fixed. The overall $\mathrm{R}(\mathrm{wp})$ is $14.1 \%$, the high value is mainly due to the noise in the background. The GOF parameter is 1.95, and $\mathrm{R}$ (Bragg) for gunningite is 3.5\% and 7.2\% for boyleite.

\section{Electrophoretic Mobility Shift Assay (EMSA)}

The influence of the particles on NF-kB DNA binding was determined by the electrophoretic mobility shift assay. $4 \times 10^{5}$ cells were seeded into 6-well plates and grown to $60-70 \%$ confluence. $24 \mathrm{~h}$ before particle treatment, the medium was changed to starvation medium ( $0 \%$ FCS). After incubation with different particle concentrations in $6 \mathrm{~mL}$ starvation medium and different time durations, nuclear extracts were obtained as described previously by Schreiber et al. ${ }^{3}$ Additionally, cells were stimulated for 30 min with human TNFa (4 ng/mL, PeproTech, Hamburg, Germany) alone (as positive control) and after pretreatment with $\mathrm{CaSO}_{4}\left(10-100 \mu \mathrm{g} / \mathrm{cm}^{2}, 6 \mathrm{~h}\right)$. The influence of ROS on NF- $\mathrm{kB}$ activation was determined by preincubation with the ROS scavengers BHA $(50-200 \mu \mathrm{M})$ and NAC $(0.5-1 \mathrm{mM}) 60 \mathrm{~min}$ before particle stimulation. The Bradford protein assay (BioRad, München, Germany) was used to determine the concentration of the nuclear protein extract. Equal amounts of the protein extract $(2-5 \mu \mathrm{g})$ were added to a reaction mixture containing $20 \mu \mathrm{g}$ of bovine serum albumin, $2 \mu \mathrm{g}$ of poly(dI-dC) (Roche Diagnostics, Mannheim, Germany), $2 \mu \mathrm{L}$ of buffer D+ (20 mM Hepes/KOH pH 7.9, 20\% glycerol, $100 \mathrm{mM} \mathrm{KCl,} 0.5$ mM EDTA, 0.25\% Nonidet P40. $2 \mathrm{mM}$ DTT. 0.1\% nhenvlmethvlsulfonvl fluoride). 4 uI of huffer F (20\% Ficoll 400. 
$100 \mathrm{mM}$ Hepes/KOH pH 7.0, $300 \mathrm{mM} \mathrm{KCl,} 10 \mathrm{mM}$ DTT, $0.1 \%$ phenylmethylsulfonyl fluoride) and $25 \mathrm{ng}$ of $\left[\gamma^{33} \mathrm{P}\right]$-labelled NF- $\mathrm{BB}$ oligonucleotide to a final volume of $21 \mu \mathrm{L}$. NFผB oligonucleotide (5'-AGT TGA GGG GAC TTT CCC AGG C-3' and 3'-TCA ACT CCC CTG AAA GGG TCC G-5', Promega, Mannheim, Germany) was labeled using $\left[\gamma^{33} \mathrm{P}\right]$ ATP (3000 Ci/mmol, Hartmann Analytic, Braunschweig, Germany) and a T4 polynucleotide kinase (New England Biolabs, Hilden, Germany). The composition of the NF-kB dimer was assessed using a supershift assay. Therefore, a specific antibody against the NF- $\kappa B$ p65 subunit (NF-kB p65, sc-7151x, Santa Cruz Biotechnology, Heidelberg, Germany) was incubated with the probe and separated in the gel. Due to the higher weight of the antibody protein DNA complex, a shift could be observed in case of the presence of the p65 subunit. Samples and reaction mixture were incubated at room temperature for $25 \mathrm{~min}$ and resolved through a non-denaturating $6 \%$ polyacrylamide gel. The gel was transferred to a Whatman $3 \mathrm{MM}$ paper and dried under vacuum at $80^{\circ} \mathrm{C}$ for $60 \mathrm{~min}$. After drying, the gel was exposed to a PhosphoImager BAS film (Fujifilm, Düsseldorf, Germany) for $24 \mathrm{~h}$. Detection was performed by a PhosphoImager. The resulting images are shown.

\section{Phospho-JNK, p53, p21 Western Blot.}

The influence of different particles on JNK, p53 and p21 was determined by Western blot analysis. $4 \times 10^{5}$ cells were seeded into 6 -well plates and grown to $60-70 \%$ confluence. The medium was changed to starvation medium $(0 \%$ FCS $) 24 \mathrm{~h}$ before stimulation. For JNK activation, the cells were treated with $10-100 \mu \mathrm{g} / \mathrm{cm}^{2} \mathrm{CaSO}_{4}$ and $5-25 \mu \mathrm{g} / \mathrm{cm}^{2} \mathrm{Zn}$ sulfate in $6 \mathrm{~mL}$ starvation medium for 12 and $24 \mathrm{~h}$. For assessment of p53 and p21, cells were treated with $100 \mu \mathrm{g} / \mathrm{cm}^{2} \mathrm{CaSO}_{4}$ or $\mathrm{PbSO}_{4}$ for $24 \mathrm{~h}$. A combination of actinomycin $\mathrm{D}(333 \mathrm{nM})$ and TNF $\alpha$ (4 ng/mL) or Paclitaxel (PTX, $6 \mathrm{nM}$ ) served as a positive control. To determine the role of ROS in JNK-activation, NAC $(0.5-2 \mathrm{mM})$ was added $60 \mathrm{~min}$ before stimulation. For preparation of total extracts, cells were washed with $\mathrm{PBS}$, centrifuged $\left(263 \mathrm{~g}, 4^{\circ} \mathrm{C}, 5 \mathrm{~min}\right)$ 
and $126 \mu \mathrm{L}$ of triton-x lysis buffer $(136 \mathrm{mM} \mathrm{NaCl}, 20 \mathrm{mM}$ Tris/HCl $\mathrm{pH}$ 7.4, 10\% glycerol, $2 \mathrm{mM}$ EDTA, $50 \mathrm{mM} \beta$-glycerophosphate, $20 \mathrm{mM}$ Na-pyrophosphate, $10 \mathrm{mM} \mathrm{NaF}, 4 \mathrm{mM}$ benzamidine, $1 \mathrm{mM}$ Na-vanadate, $1 \%$ Triton $\mathrm{X} 100$ ) supplemented with protease inhibitors (0.2 $\mathrm{mM}$ pefablock, $5 \mu \mathrm{g} / \mathrm{mL}$ aprotinin, $5 \mu \mathrm{g} / \mathrm{mL}$ leupeptin) and phosphatase inhibitors $\left(10 \mu 1 / \mathrm{mL}\right.$ PhosStop ${ }^{\circledR}$ (Roche Diagnostics, Mannheim, Germany)) were added. Cell lysis was performed by shaking $20 \mathrm{~min}$ at $4^{\circ} \mathrm{C}$. The supernatant was collected after centrifugation (20142 $\left.\mathrm{g}, 4^{\circ} \mathrm{C}, 10 \mathrm{~min}\right)$.

To analyze the protein level in the cell lysate, samples containing 30-60 $\mu$ g protein were separated by SDS-PAGE (12\% gel) and transferred to a $0.4 \mu \mathrm{m}$ pore size PVDF membrane (Roche Diagnostics, Mannheim, Germany). The blocking of unspecific antibody binding sites on the membrane was performed by incubation with 5\% milk in TBST (TBS buffer containing $0.1 \%$ Tween 20 (Carl Roth, Karlsruhe, Germany)). Antigen detection was done using antibodies against p-JNK and JNK (Cell Signaling, Boston, USA, 1:1000, $5 \%$ BSA in TBST), p53 (Sigma Aldrich, Taufkirchen, Germany, 1:5000, 5\% milk in TBST), p21 (Cell signaling Technology, Danvers, USA, 1:2000, 5\% milk in TBST) and $\beta$-actin (Sigma Aldrich, Taufkirchen, Germany1:10000, 5\% milk in TBST) and an appropriate horseradish peroxidase-labeled secondary antibody. As detection reagent, ECL advanced chemiluminescence detection reagent (GE Healthcare, Munich, Germany) was used. For JNK analysis, chemiluminescent images were taken using the LumiImager and the LumiAnalyst Software (Roche Diagnostics, Mannheim, Germany). For p53 and p21, chemiluminescence was measured by the Analyzer Universal hood (Bio Rad, München) and the Quantify one 4.6.6 Software.

\section{Caspase 3/7 assay}

For assessment of Caspase 3/7-activation, $2 \times 10^{4}$ cells were seeded into white 96-well plates and grown until confluency before exposure in $200 \mu \mathrm{L}$ culture media with $5 \%$ FBS. After 
$24 \mathrm{~h}, 100 \mu \mathrm{L}$ of Caspase 3/7-solution (Promega, Madison, WI, USA) was added and incubated at RT for $1 \mathrm{~h}$. Luminescence was measured using a microplate reader (Tecan infinite M200, Crailsheim, Germany). CPT $(10 \mu \mathrm{M})$ was included as positive control. Each experiment was performed three times independently. 


\section{TABLES}

Table 1S: Summary of laser diffraction data ( $\mu \mathrm{m}$ refer to equivalent particle diameter).

\begin{tabular}{|c|c|c|c|c|c|}
\hline & Unit & $\mathrm{CaSO}_{4}$ & $\mathrm{ZnSO}_{4} \cdot \mathrm{H}_{2} \mathrm{O}$ & Zn sulfate & $\mathrm{PbSO}_{4}$ \\
\hline Smallest particle & $\mu \mathrm{m}$ & 0.13 & 0.08 & 0.06 & 0.06 \\
\hline Largest particle & $\mu \mathrm{m}$ & 65.51 & 163.77 & 301.68 & 65.51 \\
\hline Surface area & $\mathrm{m}^{2} / \mathrm{g}$ & 0.6701 & 0.4461 & $0.3342(0.5068)^{*}$ & 1.0369 \\
\hline Maximum No\% & $\mu \mathrm{m}$ & $0.27-0.31$ & $0.17-0.20$ & $0.07-0.08$ & $0.08-0.09$ \\
\hline Maximum Vol\% & $\mu \mathrm{m}$ & $7.27-9.00$ & $53.10-60.18$ & $76.31-82.39$ & $3.60-4.19$ \\
\hline Ultrafine $(<0.1 \mu \mathrm{m})$ & No\% & $\sim 3$ & $\sim 20$ & $\sim 60$ & $>50$ \\
\hline Fine $(0.1-2.5 \mu \mathrm{m})$ & No\% & $\sim 96$ & $\sim 80$ & $\sim 35$ & $\sim 50$ \\
\hline Coarse $(2.5-10 \mu \mathrm{m})$ & No\% & $<1$ & & $\sim 5$ & \\
\hline Ultrafine $(<0.1 \mu \mathrm{m})$ & Vol\% & $<0.002$ & 0.02 & $\sim 0.12$ & 0.8 \\
\hline Fine $(0.1-2.5 \mu \mathrm{m})$ & Vol\% & $\sim 22$ & $\sim 10$ & $\sim 16$ & $\sim 55$ \\
\hline Coarse $(2.5-10 \mu \mathrm{m})$ & Vol\% & $\sim 38$ & $\sim 13$ & $\sim 9$ & $\sim 43$ \\
\hline$>10 \mu \mathrm{m}$ & Vol\% & $\sim 40$ & $\sim 77$ & $\sim 75$ & $\sim 2$ \\
\hline
\end{tabular}


Table 2S. Particles detected by scanning 80-120 A549 cells per sample (after exposure to sulfate powders and using TEM-EDX analysis). Control sample (not exposed to test materials) is not listed as no particles were found. $\mathrm{SP}=$ single particle, $\mathrm{A}=$ agglomerate, $\mathrm{C}=$ cell cytoplasm, $\mathrm{EM}=$ embedding medium, $\mathrm{S}=$ cell surface, $\mathrm{N}=$ cell nucleus, $\mathrm{V}=$ vesicle, $\mathrm{P}=$ particle.

\begin{tabular}{|c|c|c|c|c|}
\hline Sulfate sample & $\begin{array}{l}\text { Particle } \\
\text { spectrum }\end{array}$ & Occurrence & $\begin{array}{l}\text { Location in } \\
\text { sample }\end{array}$ & $\begin{array}{l}\text { No. of particles } \\
\text { No. of } A \text { and } V\end{array}$ \\
\hline \multirow[t]{5}{*}{$\mathrm{CaSO}_{4} 50 \mu \mathrm{g} / \mathrm{cm}^{2} 24 \mathrm{~h}$} & $\mathrm{Fe}-\mathrm{O}$ & $\mathrm{SP}$ & $\mathrm{C}$ & $\mathrm{C}(1 \mathrm{P})$ \\
\hline & Ca-Al-Si-O & SP & EM & $\mathrm{EM}(1 \mathrm{P})$ \\
\hline & Si-O & $\mathrm{SP}$ & C & $\mathrm{C}(1 \mathrm{P})$ \\
\hline & Al-Fe-Si & SP & $\mathrm{C} ; \mathrm{S}$ & $C(1 P) ; S(2 P)$ \\
\hline & Na-Si-O & SP & C & $\mathrm{C}(2 \mathrm{P})$ \\
\hline \multirow[t]{3}{*}{$\mathrm{CaSO}_{4} 100 \mu \mathrm{g} / \mathrm{cm}^{2} 4 \mathrm{~h}$} & Ca-S-O & $A$ & EM & $1 \mathrm{~A}(90 \mathrm{P})$ \\
\hline & $\mathrm{Fe}-\mathrm{O}$ & SP & C & $C(1 P)$ \\
\hline & Al-Si-O & SP & C & $C(1 P)$ \\
\hline \multirow[t]{5}{*}{$\mathrm{CaSO}_{4} 100 \mu \mathrm{g} / \mathrm{cm}^{2} 24 \mathrm{~h}$} & Ca-S-O & $\mathrm{SP}$ & $\mathrm{C}$ & $\mathrm{C}(1 \mathrm{P})$ \\
\hline & $\mathrm{Ca}-\mathrm{O}$ & SP & C & $C(1 P)$ \\
\hline & $\mathrm{Fe}-\mathrm{O}$ & SP & $\mathrm{C}$ & $C(1 P)$ \\
\hline & $\mathrm{Fe}-\mathrm{Cr}-\mathrm{O}$ & SP & C & $\mathrm{C}(2 \mathrm{P})$ \\
\hline & Al-Si-O & SP & $\mathrm{C} ; \mathrm{N}$ & $\mathrm{C}(1 \mathrm{P}) ; \mathrm{N}(1 \mathrm{P})$ \\
\hline Zn sulfate $1 \mu \mathrm{g} / \mathrm{cm}^{2} 24 \mathrm{~h}$ & $\mathrm{Fe}-\mathrm{O}$ & $\mathrm{SP}$ & $\mathrm{S}$ & $\mathrm{S}(1 \mathrm{P})$ \\
\hline \multirow[t]{2}{*}{ Zn sulfate $10 \mu \mathrm{g} / \mathrm{cm}^{2} 24 \mathrm{~h}$} & $\mathrm{Fe}-\mathrm{O}$ & $\mathrm{SP}$ & $\mathrm{C}$ & $\mathrm{C}(1 \mathrm{P})$ \\
\hline & Fe-Ti-O & $\mathrm{SP}$ & C & $\mathrm{C}(1 \mathrm{P})$ \\
\hline \multirow[t]{5}{*}{$\mathrm{PbSO}_{4} 100 \mu \mathrm{g} / \mathrm{cm}^{2} 4 \mathrm{~h}$} & $\mathrm{~Pb}-\mathrm{S}-\mathrm{O}$ & $A$ & $\mathrm{~V}$ & 2A( 31P\&4P) \\
\hline & $\mathrm{Pb}-\mathrm{S}-\mathrm{O}$ & $\mathrm{SP}$ & C & $\mathrm{C}(1 \mathrm{P})$ \\
\hline & $\mathrm{Pb}-\mathrm{S}-\mathrm{O}$ & $A$ & $S$ & $1 \mathrm{~A}(41 \mathrm{P})$ \\
\hline & Pb-S-O & $A$ & EM & $1 \mathrm{~A}(68 \mathrm{P})$ \\
\hline & Ca-Al-Si-O & $\mathrm{A}$ & $\mathrm{V}$ & 2A(21P\&9P) \\
\hline \multirow[t]{7}{*}{$\mathrm{PbSO}_{4} 100 \mu \mathrm{g} / \mathrm{cm}^{2} 24 \mathrm{~h}$} & $\mathrm{~Pb}-\mathrm{S}-\mathrm{O}+\mathrm{Ca}$ & $\mathrm{SP}$ & $\mathrm{C} ; \mathrm{V}$ & $\mathrm{C}(3 \mathrm{P}) ; 1 \mathrm{~V}(1 \mathrm{P})$ \\
\hline & $\mathrm{Pb}-\mathrm{S}-\mathrm{O}+\mathrm{Ca}$ & $A$ & C & $2 \mathrm{~A}(5 \mathrm{P} \& 5 \mathrm{P})$ \\
\hline & $\mathrm{Pb}-\mathrm{S}-\mathrm{O}+\mathrm{Ca}$ & $A$ & $\mathrm{~V}$ & $1 \mathrm{~A}(\sim 24 \mathrm{P})$ \\
\hline & $\mathrm{Al}-\mathrm{O}$ & $\mathrm{SP}$ & V & 6V(á 1P) \\
\hline & $\mathrm{Al}-\mathrm{O}$ & $A$ & V & $1 \mathrm{~V}(3 \mathrm{P})$ \\
\hline & Ca-Al-Si-O & $\mathrm{SP}$ & $\mathrm{C} ; \mathrm{V}$ & $\mathrm{C}(1 \mathrm{P}) ; 1 \mathrm{~V}(1 \mathrm{P})$ \\
\hline & Ca-Al-O & $\mathrm{SP}$ & V & $1 \mathrm{~V}(1 \mathrm{P})$ \\
\hline
\end{tabular}


Table 3S. Results of PHREEQC modeling at $37^{\circ} \mathrm{C}$ : Minerals that are predicted to precipitate from RPMI or particle-containing culture medium solutions $\left(100 \mu \mathrm{g} / \mathrm{cm}^{2}(160 \mathrm{ppm})\right.$ sulfate in RPMI $+5 \%$ FBS) at a $\mathrm{pH}$ of 7.4 (experimental conditions) and 4.5 (lysosomal $\mathrm{pH}$ ), respectively, are indicated by $\mathrm{X}$. 


\begin{tabular}{|c|c|c|c|c|c|c|c|c|}
\hline Formula & Mineral name & \begin{tabular}{|l} 
RPMI \\
pH 7.4
\end{tabular} & \multicolumn{2}{|c|}{$\mathrm{CaSO}_{4}$} & \multicolumn{2}{|c|}{ Zn sulfate } & \multicolumn{2}{|c|}{$\mathrm{PbSO}_{4}$} \\
\hline $\mathrm{Ca}(\mathrm{OH})_{2}$ & Portlandite & & & & & & & \\
\hline $\mathrm{Ca}_{3}\left(\mathrm{PO}_{4}\right)_{2}$ & Whitlockite & $\mathrm{x}$ & $\mathrm{x}$ & & $\mathrm{x}$ & & $\mathrm{x}$ & \\
\hline $\mathrm{Ca}_{5}(\mathrm{OH})\left(\mathrm{PO}_{4}\right)_{3}$ & Hydroxylapatite & $\mathrm{x}$ & $x$ & & $\mathrm{x}$ & & $\mathrm{x}$ & \\
\hline $\mathrm{CaCl}_{2}$ & Hydrophilite & & & & & & & \\
\hline $\mathrm{CaCO}_{3}$ & Aragonite & & $\mathrm{x}$ & & $x$ & & $\mathrm{x}$ & \\
\hline $\mathrm{CaCO}_{3}$ & Calcite & $\mathrm{x}$ & $\mathrm{x}$ & & $\mathrm{x}$ & & $\mathrm{x}$ & \\
\hline $\mathrm{CaCO}_{3} \cdot \mathrm{H}_{2} \mathrm{O}$ & Monohydrocalcite & & & & & & & \\
\hline $\mathrm{CaFe}_{2} \mathrm{O}_{4}$ & Ferrite-Ca & & $\mathrm{x}$ & & $\mathrm{x}$ & & $\mathrm{x}$ & \\
\hline $\mathrm{CaMg}\left(\mathrm{CO}_{3}\right)_{2}$ & Dolomite & $x$ & $x$ & & $x$ & & $x$ & \\
\hline $\mathrm{CaSO}_{4}$ & Anhydrite & & & & & & & \\
\hline $\mathrm{CaSO}_{4} \cdot 0.5 \mathrm{H}_{2} \mathrm{O}$ & Bassanite & & & & & & & \\
\hline $\mathrm{CaSO}_{4} \cdot 2 \mathrm{H}_{2} \mathrm{O}$ & Gypsum & & & & & & & \\
\hline $\mathrm{Fe}\left(\mathrm{CO}_{3}\right)$ & Siderite & & & & & & & \\
\hline $\mathrm{Fe}(\mathrm{OH})_{3}$ & Iron(III) hydroxide & & $\mathrm{x}$ & & $\mathrm{x}$ & & $\mathrm{x}$ & \\
\hline $\mathrm{Fe}_{2} \mathrm{O}_{3}$ & Hematite & & $\mathrm{x}$ & & $\mathrm{x}$ & & $\mathrm{x}$ & \\
\hline $\mathrm{Fe}_{3} \mathrm{O}_{4}$ & Magnetite & & $\mathrm{x}$ & & $x$ & & $\mathrm{x}$ & \\
\hline $\mathrm{FeO}(\mathrm{OH})$ & Goethite & & $x$ & & $x$ & & $\mathrm{x}$ & \\
\hline $\mathrm{FePO}_{4} \cdot 2 \mathrm{H}_{2} \mathrm{O}$ & Strengite & & & & & & & \\
\hline $\mathrm{KCl}$ & Sylvite & & & & & & & \\
\hline $\mathrm{KFe}_{3}\left(\mathrm{SO}_{4}\right)_{2}(\mathrm{OH})_{6}, \mathrm{NaFe}_{3}\left(\mathrm{SO}_{4}\right)_{2}(\mathrm{OH})_{6}$ & Jarosite & & & & & & & \\
\hline $\mathrm{K}_{2} \mathrm{SO}_{4}$ & Arcanite & & & & & & & \\
\hline $\mathrm{Mg}(\mathrm{OH})_{2}$ & Brucite & & & & & & & \\
\hline $\mathrm{MgCl}_{2}$ & & & & & & & & \\
\hline $\mathrm{MgCO}_{3}$ & Magnesite & & & & & & & \\
\hline $\mathrm{MgFe}_{2} \mathrm{O}_{4}$ & Ferrite-Mg & & $x$ & & $x$ & & $x$ & \\
\hline $\mathrm{MgO}$ & Periclase & & & & & & & \\
\hline $\mathrm{MgSO}_{4}, \mathrm{MgSO}_{4} \cdot \mathrm{nH}_{2} \mathrm{O}$ & Magnesium sulfate & & & & & & & \\
\hline $\mathrm{Na}_{2} \mathrm{Ca}\left(\mathrm{SO}_{4}\right)_{2}$ & Glauberite & & & & & & & \\
\hline $\mathrm{Na}_{2} \mathrm{SO}_{4}$ & Thenardite & & & & & & & \\
\hline $\mathrm{NaCl}$ & Halite & & & & & & & \\
\hline $\mathrm{Pb}_{2}\left(\mathrm{CO}_{3}\right) \mathrm{Cl}_{2}$ & Phosgenite & & & & & & & \\
\hline $\mathrm{Pb}_{2}\left(\mathrm{SO}_{4}\right) \mathrm{O}$ & Lanarkite & & & & & & & \\
\hline $\mathrm{Pb}_{2} \mathrm{Cl}_{2} \mathrm{CO}_{3}$ & & & & & & & & \\
\hline $\mathrm{Pb}_{3}\left(\mathrm{PO}_{4}\right)_{2}$ & & & & & & & $x$ & $x$ \\
\hline $\mathrm{Pb}_{3} \mathrm{SO}_{6}$ & & & & & & & & \\
\hline $\mathrm{Pb}_{4} \mathrm{Cl}_{2}(\mathrm{OH})_{6}$ & & & & & & & & \\
\hline $\mathrm{Pb}_{4} \mathrm{O}\left(\mathrm{PO}_{4}\right)_{2}$ & & & & & & & $\mathrm{x}$ & \\
\hline $\mathrm{Pb}_{4} \mathrm{SO}_{7}$ & & & & & & & & \\
\hline $\mathrm{Pb}_{5}(\mathrm{OH})\left(\mathrm{PO}_{4}\right)_{3}$ & Pyromorphite-OH & & & & & & $x$ & \\
\hline $\mathrm{Pb}_{5}\left(\mathrm{PO}_{4}\right)_{3} \mathrm{Cl}$ & Pyromorphite & & & & & & $\mathrm{x}$ & $\mathrm{x}$ \\
\hline $\mathrm{PbCl}(\mathrm{OH})$ & Paralaurionite & & & & & & & \\
\hline $\mathrm{PbCl}_{2}$ & Cotunnite & & & & & & & \\
\hline $\mathrm{PbCO}_{3}$ & Cerussite & & & & & & $x$ & \\
\hline $\mathrm{Pb}_{3}\left(\mathrm{CO}_{3}\right)_{2}(\mathrm{OH})_{2}$ & Hydrocerussite & & & & & & $\mathrm{x}$ & \\
\hline $\mathrm{PbFe}_{3}\left(\mathrm{PO}_{4}\right)\left(\mathrm{SO}_{4}\right)(\mathrm{OH})_{6}$ & Corkite & & & & & & & \\
\hline $\mathrm{PbHPO}_{4}$ & & & & & & & $x$ & $\mathrm{x}$ \\
\hline $\mathrm{PbSO}_{4}$ & Anglesite & & & & & & & \\
\hline $\mathrm{Zn}(\mathrm{OH})_{2}$ & Zinc hydroxide & & & & & & & \\
\hline $\mathrm{Zn}_{2}(\mathrm{OH})_{3} \mathrm{Cl}$ & & & & & & & & \\
\hline $\mathrm{Zn}_{2} \mathrm{SO}_{4}(\mathrm{OH})_{2}$ & & & & & & & & \\
\hline $\mathrm{Zn}_{3}\left(\mathrm{PO}_{4}\right)_{2} \cdot 4 \mathrm{H}_{2} \mathrm{O}$ & Hopeite & & & & $x$ & & & \\
\hline $\mathrm{Zn}_{5}\left(\mathrm{NO}_{3}\right)_{2}(\mathrm{OH})_{8}$ & & & & & & & & \\
\hline $\mathrm{Zn}_{5}(\mathrm{OH})_{6}\left(\mathrm{CO}_{3}\right)_{2}$ & Hydrozincite & & & & $x$ & & & \\
\hline $\mathrm{ZnCl}_{2}$ & Zinc chloride & & & & & & & \\
\hline $\mathrm{ZnCO}_{3}$ & Smithsonite & & & & $\mathrm{x}$ & & & \\
\hline $\mathrm{ZnCO}_{3} \cdot \mathrm{H}_{2} \mathrm{O}$ & & & & & $\mathrm{x}$ & & & \\
\hline $\mathrm{ZnFe}_{2} \mathrm{O}_{4}$ & Ferrite-Zn & & $x$ & & $x$ & & $\mathrm{x}$ & \\
\hline $\mathrm{ZnO}$ & Zincite & & & & $x$ & & & \\
\hline $\mathrm{ZnSO}_{4}$ & Zincosite & & & & & & & \\
\hline $\mathrm{ZnSO}_{4} \cdot 6 \mathrm{H}_{2} \mathrm{O}$ & Zinc sulfate hexahydrate & & & & & & & \\
\hline $\mathrm{ZnSO}_{4} \cdot 7 \mathrm{H}_{2} \mathrm{O}$ & Goslarite & & & & & & & \\
\hline $\mathrm{ZnSO}_{4} \cdot \mathrm{H}_{2} \mathrm{O}$ & Gunningite & & & & & & & \\
\hline
\end{tabular}




\section{FIGURES}

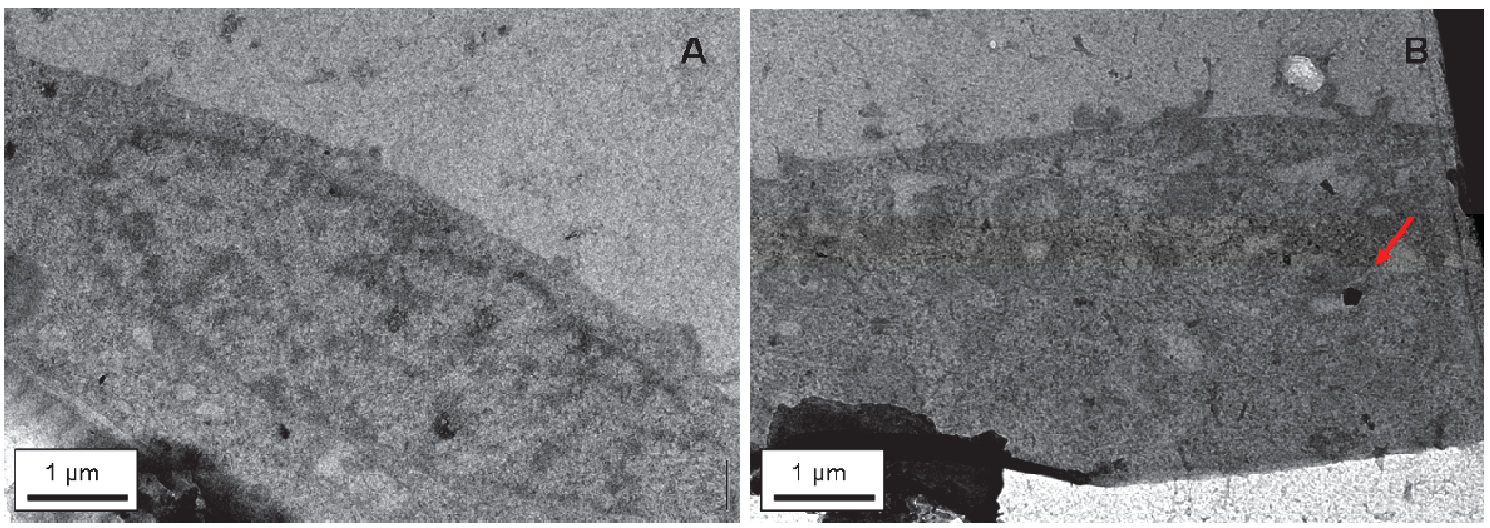

Figure 1S. TEM images of A549 cells exposed to $\mathrm{CaSO}_{4}$ (A) $100 \mu \mathrm{g} / \mathrm{cm}^{2} 4 \mathrm{~h}$, and (B) $100 \mu \mathrm{g} / \mathrm{cm}^{2} 24 \mathrm{~h}$. Red arrow indicates the only $\mathrm{CaSO}_{4}$ particle found (after scanning 80-120 cells per sample). It is located in a vesicle.

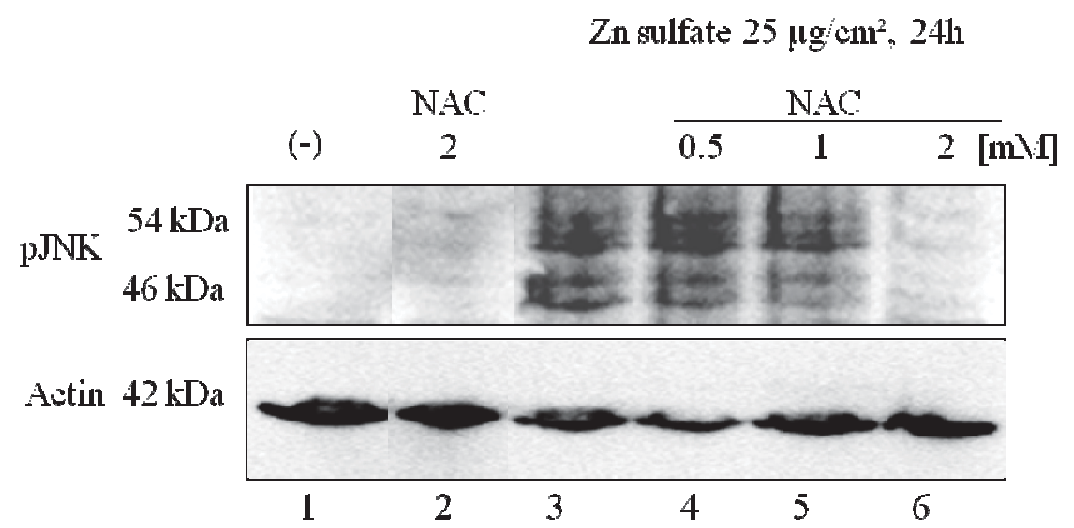

Figure 2S. Effect of NAC pretreatment on particle-induced JNK activation. Cells were treated with $\mathrm{Zn}$ sulfate $\left(25 \mu \mathrm{g} / \mathrm{cm}^{2}, 24 \mathrm{~h}\right)$ for the indicated times (lanes $\left.3-6\right)$ with and without $1 \mathrm{~h}$ pretreatment with NAC $(0.5-2 \mathrm{mM})$; lane 1 shows untreated cells, in lane 2 cells were treated $2 \mathrm{mM}$ NAC for $25 \mathrm{~h}$. 


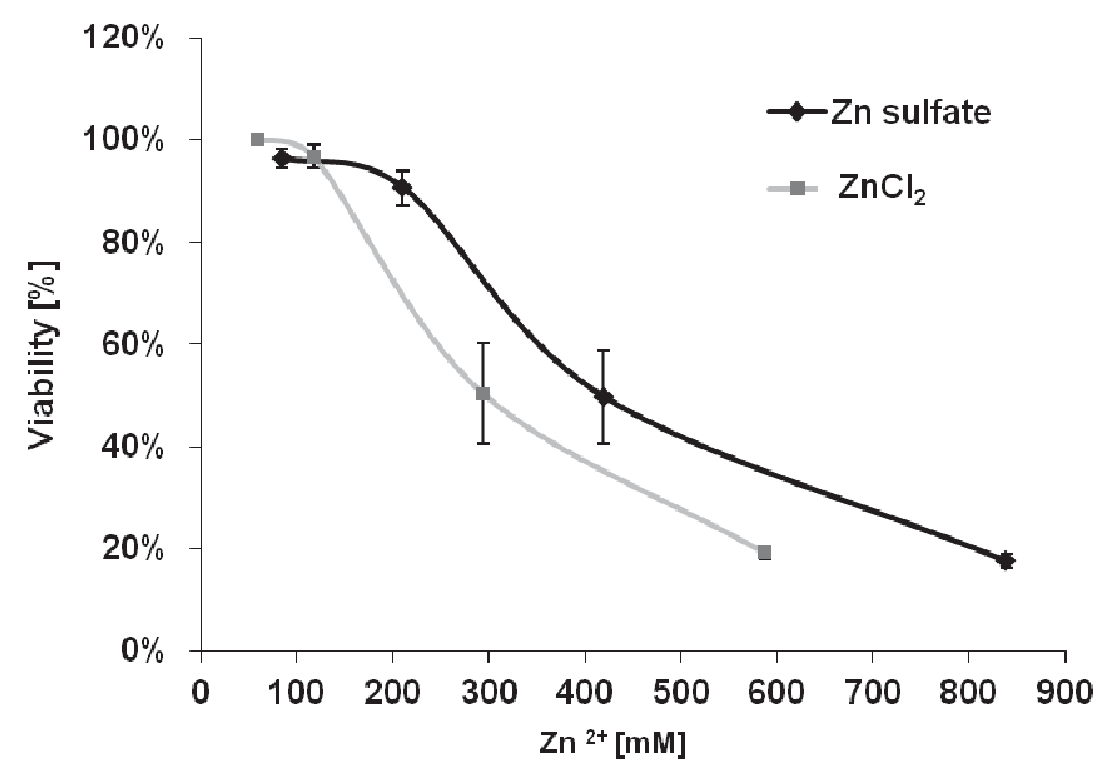

Figure 3S. Cell viability of $\mathrm{Zn}$ sulfate and $\mathrm{ZnCl}_{2}$ calculated as corresponding $\mathrm{Zn}^{2+}$ concentrations following 24-h exposure in human lung cells (A549), monitored by the WST assay. Results are expressed as percent viable cells compared to untreated control. Each bar represents the mean $\pm \mathrm{SE}$ of three independent experiments.

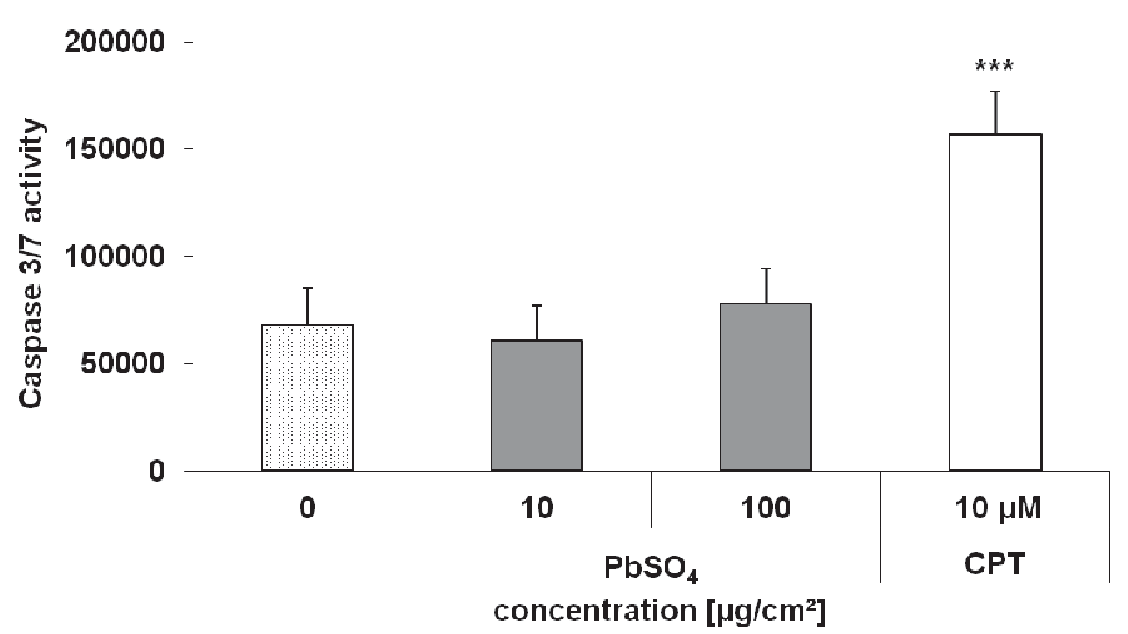

Figure 4S. Caspase 3/7-activity in A549 cells after 24-h exposure to suspensions containing $\mathrm{PbSO}_{4}$. CPT $(10 \mu \mathrm{M})$ was used as positive control. Each bar represents the mean $\pm \mathrm{SD}$ of three independent experiments. ${ }^{*} \mathrm{p}<0.05,{ }^{* *} \mathrm{p}<0.01,{ }^{* * *} \mathrm{p}<0.001$ versus untreated control (One-way ANOVA followed by Dunnett's post-hoc). 


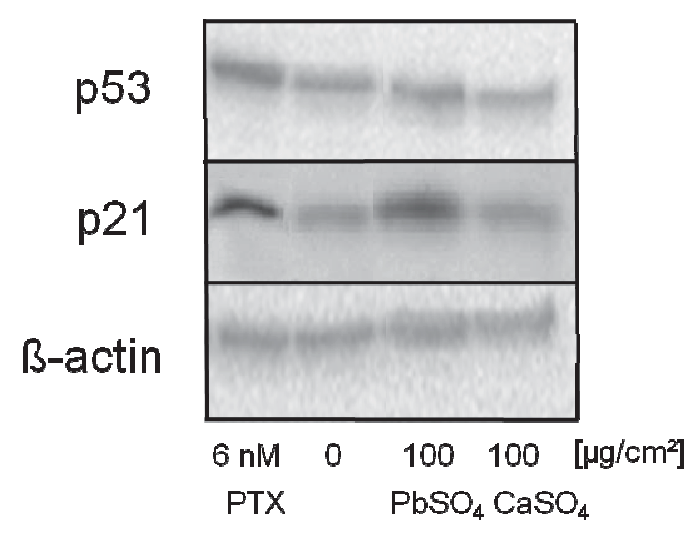

Figure 5S. Activation of p53 and p21 by $\mathrm{PbSO}_{4}$ and $\mathrm{CaSO}_{4}$ in $\mathrm{A} 549$ cells after $24 \mathrm{~h}$ measured by Western blot analysis. Lane 1 shows $16 \mathrm{~h}$ treatment with PTX $(6 \mathrm{nM})$ as the positive control, lane 2 shows untreated cells after $24 \mathrm{~h}$. One representative Western blot is shown.

\section{References}

(1) Wildner, M., Geister, G. (1991) Neues Jahrbuch für Mineralogie, Monatshefte 1991, 296-30.

(2) Blake, A. J., Cooke, P. A., Hubberstey, P., Sampson, C. L. (2001) Acta Crystallogr., Sect. E: Struct. Rep. Online 57, 109-111.

(3) Schreiber, E., Matthias, P., Müller, M. M., and Schaffner, W. (1989) Rapid Detection of Octamer Binding-Proteins with Mini-Extracts, Prepared from A Small Number of Cells. Nucleic. Acids Res. 17(15), 6419. 